\title{
BIOÉTICA E DIREITOS HUMANOS
}

\section{A PROTEÇÃO DA DIGNIDADE DA PESSOA HUMANA NA ERA DA GENÉTICA}

\section{Introdução:}

"As ideias belas e verdadeiras pertencem a todos". (Sêneca)

A ciência aplicada aos avanços da biotecnologia torna evidente a criatividade e capacidade humana de transformação e fomento da sua liberação em reação às contingências do mundo natural. As mais modernas técnicas de engenharia genética inserem-se nesse contexto de desenvolvimento biotecnológico - que tem, sem dúvidas, dado luz aos maiores questionamentos quanto à natureza humana. Como bem define Sgreccia, ao referir-se à genética contemporânea, "encontramo-nos sem dúvida nenhuma diante de um momento crucial da história da ciência e da história da humanidade"

De fato, as inovações nesse campo da ciência acabaram por colocar a humanidade frente a situações até pouco tempo inimagináveis, como terapias gênicas e clonagem humana. E se por um lado a manipulação dos genes trouxe renovadas esperanças de cura para várias doenças e de melhoria da qualidade de vida em um sentido amplo, por outro lado criou uma série de incertezas, angústias e contradições, que devem ser analisadas cuidadosamente pela sociedade.

As aplicações atuais da engenharia genética demonstram um caráter ambivalente, de proteção e afronta concomitante a diversos princípios de direitos humanos, porquanto incluem certas situações de possível proteção e outras de ofensa ao núcleo axiológico da noção de dignidade da pessoa humana.

\footnotetext{
${ }^{1}$ SGRECCIA, E. Manual de bioética. Fundamentos e ética biomédica. São Paulo: Loyola, 1996, p. $213 / 214$.
} 
Desde já, revela-se, portanto, a importância do trabalho ora em tela, o qual terá como fio condutor a proteção da pessoa humana e dos direitos humanos quando afrontados por questões relacionadas à genética. Busca-se contribuir de modo relevante para a atividade de médicos, pesquisadores, membros de comitês de ética, advogados e juízes, demonstrando o quanto suas atividades encontram-se abrangidas pela natureza pluralista da bioética e o quão necessária é a relação estabelecida entre essa e os direitos humanos.

A bioética, que nasceu como uma resposta natural da sociedade às angústias e incertezas humanas erigidas ao longo do século XX, face aos avanços da ciência, visa, assim como o direito, à proteção da dignidade da pessoa humana diante dos dilemas oferecidos pelas sociedades complexas, nas quais as técnicas de engenharia genética são cada vez mais presentes.

Neste plano, o direito e a bioética (na qual se inclui a ética) apresentam-se como protagonistas para a proteção humana - do que decorre a íntima relação existente entre essas disciplinas que se pretende ressaltar ao longo desse trabalho. Ambos têm por dever a determinação e proteção dos princípios considerados mais relevantes para a manutenção e desenvolvimento de cada pessoa e da sociedade humana ${ }^{2}$.

Quanto ao direito, é clara a sua importância para a ordenação e controle social. Ademais, assim como a bioética, o direito contribui para o esclarecimento sobre os valores de uma sociedade em um determinado espaço tempo-geográfico e no âmbito internacional. As discussões sobre a extensão dos direitos humanos encontram-se no centro das questões bioéticas, pois cumprem o papel de juridificar a noção de dignidade da pessoa humana e de consubstanciar o seu conteúdo.

\footnotetext{
${ }^{2}$ Assim, considerando-se que o direito revela os valores mais fundamentais à uma sociedade historicamente determinada, quando "uma norma jurídica proíbe a terapia gênica em linha germinal, a experimentação com embriões, a clonagem reprodutiva humana, não só pretende regular determinadas situações que se apresentam como novidades no campo da ciência, mas paralelamente expressar os valores de uma sociedade em um dado momento". Tradução livre de: "una norma juridica prohíbe la terapia génica en línea germinal, la experimentación con embriones, la clonación reproductiva humana, no sólo pretende regular determinadas situaciones que se presentan como novedosas en el campo de la ciencia, sino que paralelamente está expresando los valores de una sociedad determinada en un momento dado”. BERGEL, Salvador Darío. Los derechos humanos entre la bioética y la genética. In: Acta Bioethica, 2002, año VIII, nº 02, p. 329.
} 
A bioética, por sua vez, expande a dimensão dos direitos humanos, como bem anota Bergel (2002, p. 329):

Toda uma série de novos direitos - alguns já consolidados e outros em processo de sê-lo - tais como o direito à proteção do genoma humano contra práticas contrárias à dignidade do indivíduo, à autodeterminação genética, à privacidade genética, à não-discriminação por razões genéticas, ao consentimento livre e informado para a realização de estudos genéticos, etc., determinam uma nova dimensão dos Direitos Humanos, categoria histórica que permanentemente em seu caminho foi adaptando-se aos requerimentos e às necessidades do momento, para proteger o homem na sua dignidade e na sua liberdade"3.

É de se ressaltar, inclusive, que a preocupação emergente com os temas de bioética conduziu à formação de um novo ramo do direito internacional, especificamente direcionado aos questionamentos suscitados pela aplicação da medicina e da biotecnologia em seres humanos - que, por envolver o gênero humano, "pretende conformar uma série de princípios que escapam à existência de fronteiras fechadas",

Quando advogamos a interação entre o direito e a bioética não nos referimos exclusivamente à deontologia médica, mas sustentamos que conceitos jurídicos e bioéticos, bem como a metodologia utilizada para a solução de conflitos envolvendo princípios definidores dos valores mais fundamentais à pessoa humana são de utilidade para ambos, quando diante de casos concretos relacionados a aplicações de engenharia genética.

Consideramos que os comitês de ética poderiam utilizar o método judicial de ponderação dos princípios, como modelo plausível de racionalidade prática. Os membros desses comitês estão em situação análoga a dos juízes que têm diante de si casos jurídicos que devam ser solucionados com base em princípios definidos como fundamentais à

\footnotetext{
${ }^{3}$ Tradução livre de: "Toda una serie de nuevos derechos - algunos ya consolidados y otros en proceso de serlo-tales como el derecho a la proteccíon del genoma humano contra prácticas contrarias a la dignidad del individuo, a la autodeterminación genética, a la privacidad genética, a la no-discriminación por razones genéticas, al consentimiento libre y informado para la realización de estudios genéticos, etc., conforman una nueva dimensión de los Derechos Humanos, categoría histórica que permanentemente en su camino fue adaptándose a los requerimientos y a las necesidades del momento, para proteger al hombre en su dignidad y en su libertad".

${ }^{4}$ Tradução livre de "pretende conformar una serie de principios que escapan a la existencia de fronteras cerradas". BERGEL, 2002, p. 319.
} 
natureza humana ${ }^{5}$. Aos juízes, por sua vez, têm sido apresentados princípios como da beneficência e da responsabilidade, que até pouco tempo não faziam parte do vocabulário legal. Incontestável, portanto, é o foco prático do presente trabalho, embora presente seu substrato teórico.

Quanto à ética (parte necessária da bioética) parece restar clara sua importância para a proteção do núcleo axiológico da dignidade da pessoa humana.

A ética "visa à promoção ótima da pessoa: ela é o questionamento sobre o ideal, a busca dos melhores caminhos de crescimento para a humanidade" 6 . A ética interroga, portanto, cada indivíduo sobre suas ações, sobre os princípios que devem ser protegidos. Ela não tem força jurídica, mas funciona como freio invisível aos abusos da conduta científica e como fonte implícita de princípios de direitos humanos.

Neste ponto, marcamos que, diante das questões que colocam em causa as escolhas da sociedade, é fundamental que a decisão seja levada ao debate público, sublinhando o necessário caráter pluralista de uma sociedade democrática.

\footnotetext{
Assim definida, compreende-se que a bioética não é propriamente falando nem uma nova disciplina, nem uma nova ciência, nem uma nova ética. Ela se situa, a respeito das questões postas pela biomedicina, no cruzamento entre três tipos de disciplinas científicas: as tecnociências, tais como a medicina, a biologia, assim como suas diversas especialidades; as ciências humanas, entre as quais a sociologia, a economia, a psicologia, a psicanálise ou a ciência política; outras disciplinas, por fim, como a ética, o direito, a filosofia e a teologia.
}

Assim, pode-se dizer que a bioética é um método de pesquisa interdisciplinar colocado em ação com o objetivo de desenvolver uma reflexão ética e de construir um saber teórico-prático sobre as questões colocadas ao ser humano e às sociedades pelos progressos da biomedicina. Nessa linha, o que está em jogo na bioética parece ser uma abordagem global do conhecimento mediante a qual a racionalidade científica e a racionalidade ética procurarão se unir? ${ }^{7}$

\footnotetext{
${ }^{5}$ ATIENZA, Manuel. Juridificar la bioética. In: Bioética y Derecho. Fundamentos y problemas actuales. Rodolfo Vazquez (org.) México: Fondo de Cultura Econômica, 2002, p. 91.

${ }^{6}$ DURAND, Guy. Introdução geral à bioética: História, conceitos e instrumentos. Trad. Nicolás Nyimi Campanário. São Paulo: Loyola, 2003, p. 83.

${ }^{7}$ CADORÉ, Bruno. L'expérience bioethique de la responsabilité, p. 21/22. Apud DURAND, Op. Cit., p. 107.
} 
Tal signo democrático deve possibilitar que "indivíduos pertencentes a comunidades morais diversas possam considerar-se unidos por uma estrutura comum que permita a resolução dos conflitos com o suficiente grau de consenso" ${ }^{\text {} 8 ~-~ c o m o ~ b e m ~ a n o t a ~}$ Casado Gonzalez ${ }^{9}$. De fato, em sociedades democráticas, como a que pretende ser a brasileira, os problemas que afetam os seus valores mais fundamentais, como no caso das implicações éticas trazidas pelas técnicas de engenharia genética, devem ser debatidos em um contexto participativo e informado, antes da eleição de respostas normativas e éticas.

É necessário que se persiga o consenso acerca dos limites a serem fixados à liberdade pessoal e de pesquisa. Para Casado Gonzalez (2002, p. 185), com quem concordamos, "convém centrar a busca do compromisso na elaboração de regras de jogo aceitáveis para a maioria dos cidadãos independentemente de suas opções ideológicas" ${ }^{\text {"10 }}$. Nesse sentido, as comissões de bioética e os comitês de ética possuem relevante função de promover o debate informado, plural e democrático e, assim, contribuir para a formação de políticas públicas na área de bioética.

Diante da importância da bioética (na qual se inclui a ética) e do direito, como braços de proteção da pessoa humana e dos direitos humanos quando afrontados por questões relacionadas à genética ou mesmo a outros campos da ciência, ambos estarão em foco como bases desse trabalho.

O primeiro capítulo aborda a afirmação da máxima da dignidade humana e sua importância como princípio estruturante de todo o sistema ético e jurídico. O segundo capítulo introduz a bioética. São expostos os princípios proclamados pela bioética: autonomia, beneficência, não-maleficência e justiça e estabelecida a relação necessária entre a bioética e os direitos humanos, determinando a consubstancialidade entre eles.

\footnotetext{
${ }^{8}$ Tradução livre de: “individuos pertencientes a 'comunidades morales' diversas puedan considerarse ligados por una estructura común que permita la resolución de los conflictos con el suficiente grado de acuerd".o

${ }_{9}^{9}$ CASADO GONZALEZ, María. ¿POR QUÉ BIOÉTICA Y DERECHO?. Acta bioethica., 2002, vol.8, no.2, p.183-193.

${ }^{10}$ Tradução livre de: "conviene centrar la búsqueda del compromiso en la elaboración de unas reglas del juego aceptables para la mayoría de los ciudadanos independientemente de sus opciones ideológicas".
} 
Uma vez definida a importância da proteção da dignidade humana e a relação existente entre essa, a bioética e os direitos humanos, o trabalho expõe de forma analítica, nos capítulos sucessivos, os dois braços de salvaguarda de tal base.

No primeiro deles, a ética é abordada como instrumento de proteção da sociedade que deve ser manejado segundo uma perspectiva universalista e dialógica, pois inserida em contexto democrático.

No segundo deles, o direito é exposto no seu âmbito internacional - que tem consagrado declarações de direitos humanos específicas aos temas de bioética -, e nacional, seja em relação ao substrato constitucional quanto ao infra-constitucional de proteção dos princípios envolvidos nas discussões bioéticas. 


\section{CAPÍTULO I- BIOÉTICA E DIREITOS HUMANOS - Uma relação necessária}

\section{A nocão de dignidade da pessoa humana. Sua relação necessária com} os direitos humanos e a bioética.

Embora a noção moderna de dignidade da pessoa humana tenha sido construída pela doutrina alemã, o valor fundador deste princípio nos remete ao período axial das civilizações e ao imperativo categórico kantiano - que o submete ao racionalismo, enunciando a idéia de pessoa, "como unidade consciente e certa de si mesma. É nela que, pela primeira vez se realiza a idéia do fim em si mesmo e do fim último"11.

Karl Jaspers entendeu ser possível dividir toda a história humana em dois grandes períodos, cujo marco divisor - verdadeiro eixo histórico da humanidade -, localizado entre os séculos VIII e II a. C, chamou de período Axial. Durante estes séculos teriam coexistido alguns dos maiores pensadores de todos os tempos: "Zaratustra na Pérsia, Buda na Índia, Lao-Tsé e Confúcio na China, Pitágoras na Grécia e o Dêutero-Isaías em Israel" ${ }^{\prime 2}$, os quais teriam projetado as idéias que fundaram o pensamento do segundo período da história da humanidade, com o abandono das explicações meramente mitológicas. Durante o referido período axial, no século V a. C. - século de Péricles - teria nascido a filosofia e o saber racionalista, determinantes para a consolidação da tradição ética ocidental. De fato, doravante, as religiões passaram a se afastar dos rituais fantásticos e se tornaram mais éticas, como bem anota o Professor Comparato (2006, p. 39):

\footnotetext{
Em lugar dos antigos cultos da natureza, ou da adoração dos soberanos políticos, busca-se alcançar uma esfera transcendental ao mundo e aos homens; ou, então, como na China, desenvolve-se a veneração aos antepassados, não como divindades, mas como modelos éticos para as novas gerações.
}

\footnotetext{
${ }^{11}$ Nas palavras de Kant: "De acordo com este princípio, um ser humano é um fim para si mesmo, bem como para outros, e não é suficiente não estar ele autorizado a usar a si mesmo ou a outros meramente como meios (uma vez que ele poderia, neste caso, ainda ser indiferente a eles); é em si mesmo seu dever fazer do ser humano como tal seu fim". KANT, Immanuel. Fundamentos da metafísica dos costumes. São Paulo: Ediouro 2003, p. 239.

${ }^{12}$ COMPARATO, Fábio Konder. Ética: Direito, moral e religião no mundo moderno. São Paulo: Companhia das Letras, 2006, p. 38.
} 
Destarte, o período Axial da história revela sua relevância ao significar marco para o desenvolvimento de tal concepção da humanidade, fundada na igualdade natural de seus membros e na noção de "amor ao próximo" (revisitada por Kant) essencial para o desenvolvimento do direito natural e, posteriormente, dos direitos humanos.

Some-se a isso o desenvolvimento da filosofia com base no pensamento estóico, que apregoava o saber racionalista como atributo unificador da humanidade, possibilitando "o despertar da consciência da unidade do gênero humano",13, dando causa à universalização de uma ética humanitária. De fato, é de se ressaltar a relevante influência da filosofia estóica - que teve como seus principais representantes Zenão de Cítio, na Grécia, e Sêneca, Epiteto e Marco Aurélio, em Roma - desenvolvida em um contexto de decadência das cidades-Estados gregas; momento em que se organizaram os grandes impérios macedônico e, posteriormente, romano. Os estóicos viam o mundo como um grande cosmos, regido pela natureza e pela razão, no qual cada ser se incluiria com uma função precisa, extraindo, dessa premissa, a conclusão de que o bem supremo seria reger a vida segundo os ditames da razão, da consciência e da regularidade cósmica. Ademais, a idéia de direito natural fundado na máxima do amor ao próximo - princípio fundamental da filosofia estóica - é definida por Comparato (2006, p. 112) como sendo um Leitmotiv de toda a ética formulada por Cícero, ao preconizar a noção de que a vida de todas as pessoas desenvolver-se-ia encerrada em um "conjunto de três círculos concêntricos", em que o mais abrangente incluiria todo o gênero humano - que possuiria uma unidade intrínseca.

Registre-se, contudo, que, como bem sublinha o próprio Prof. Comparato, "foi incontestavelmente com o cristianismo que o conceito de pessoa como substância, em correlação com o seu sentido concreto de indivíduo, foi sistematicamente elaborado"14. De fato, o monoteísmo trouxe à humanidade norte unívoco para o julgamento das ações humanas: as palavras de Deus submergem como fonte absoluta para o Direito, a justiça e a ética. Tal noção contribuiu de forma relevante para o desenvolvimento de uma concepção de Lei natural universal - preconizada pelos estóicos, consoante já referido. Ou seja,

\footnotetext{
${ }^{13}$ COMPARATO, 2006, p. 86/87.

${ }^{14}$ Idem, ibidem p. 479.
} 
possibilitou a idéia de que ainda que os povos possuíssem códigos morais diversos, seria de rigor que houvesse ditames universais, pois provenientes das palavras de Deus, dirigida a toda a humanidade.

$\mathrm{Na}$ esteira do pensamento cristão e retomando a racionalidade apregoada pela filosofia estóica, Tomás de Aquino utilizando a expressão "dignitas humana" referiuse à concepção de que o homem teria sido criado à imagem e semelhança de Deus - o que lhe teria garantido uma dignidade inerente. Aduz, ainda, o filósofo do medievo, que a racionalidade da pessoa humana seria a prova da dignidade humana, em virtude de ser o homem livre por natureza. Alguns séculos depois, Pico della Mirandola, humanista do Renascimento, considerou que a racionalidade seria inerente ao serhumano e que tal qualidade lhe permitiria construir seu futuro e sua existência de forma livre e autônoma. Sustentou que, ao contrário dos demais animais - que se encontram regulados por leis divinas -, o homem estaria destinado à natureza indefinida, subordinado ao seu livre-arbítrio, soberano na sua existência, pois dotado de razão. Da autonomia para escolher os rumos de sua vida, derivaria a dignidade essencial do homem.

Com o jusnaturalismo, a dignidade humana passou por processo de laicização e racionalização, mantendo-se a noção de que todos os homens, em razão de sua personalidade humana, possuem igual dignidade e liberdade. A concepção jusnaturalista moderna, destacada pela valorização da autoconsciência, forneceu as bases dos direitos humanos e serviu de apoio às reivindicações do século XVIII, que desembocaram nas declarações de direitos e nas constituições modernas. ${ }^{15}$

O direito natural moderno - deontológico, laico, individualista - foi fruto das idéias iluministas e propugnava uma ética transcendental, universalizante, segundo a qual todo homem transportaria dentro de si uma "lei ética de evitar o mal e fazer o bem $^{\prime 16}$. Buscou-se estabelecer um direito natural individual que, tendo por base a doutrina do contrato social, impusesse limites ao poder de intervenção do Estado na esfera de liberdade individual. Para Samuel Pufendorf, a dignidade humana residiria na

\footnotetext{
${ }^{15}$ Cf. PÉREZ LUÑO, Antonio Enrique. Derechos Humanos, Estado de Derecho y Constituición. Madrid: Tecnos, 1984, p. 145.

${ }^{16}$ SAMPAIO, José Adércio Leite. Direitos fundamentais. Belo Horizonte: Del Rey, 2004, p. 61.
} 
possibilidade do ser-humano agir com liberdade de convicção, conforme os ditames da razão - retomando, portanto, a noção estóica de dignidade como compartilhamento da razão.

Com Kant, consolida-se o processo de secularização da dignidade humana, com a construção de suas bases sobre a razão humana, considerada a categoria universal comum a todos os seres humanos - que seria, portanto, valor fundante de sua dignidade.

Desde então, a noção de pessoa humana encontra-se vinculada à idéia de autonomia, de um sujeito moral participativo e responsável, que ostenta uma dignidade intrínseca. Segundo Lucien Sève:

A pessoa, escreve então Kant na Metafísica dos costumes, é aquele sujeito o qual as ações são suscetíveis de imputação, o que significa que ele pode ser visto não como causa passiva mas como ator responsável porque livre, sendo capaz de agir, em virtude de representações morais independentes de toda determinação sensível $^{17}$.

De fato, procurou o filósofo alemão travar uma separação absoluta entre as coisas e os seres humanos, considerando que, enquanto uma coisa tem valor econômico (preço) ou afetivo (relativo), os seres humanos não têm preço e seu valor independe da afeição, pois têm a substância de pessoa, e a pessoa é um fim em si mesmo; ela nunca pode ser considerada um meio, ainda que nobre ${ }^{18}$. Concebeu, assim, a noção de reino dos fins em consonância com o importante mandamento do amor ao próximo, do qual emergiu a idéia de unidade do gênero humano.

Do valor inerente ao ser-humano, como um fim em si mesmo, deduziu, por conseguinte, a máxima: "Aja de tal modo que você trate a humanidade tanto em sua pessoa como na pessoa de todos os outros sempre ao mesmo tempo como fim, e jamais

\footnotetext{
${ }^{17}$ Tradução livre de: "La personne écrit ainsi Kant dans as Métaphysique des moeurs, est ce sujet dont les actions sont susceptibles d'imputation, ce qui signifie qu'il peut em être regardé non comme cause passive mais comme acteur responsable parce que libre, étant capable d'agir em vertu de représentations morales indépendantes de toute détermination sensible”. SÈVE, Lucien. Qu'est-ce que la persone humaine? Bioethique et démocratie. Paris: La Dispute, 2006, p. 38.

${ }^{18}$ Cf. COMPARATO, 2006, p. 297.
} 
como simples meio”. Ou seja, a noção de dignidade humana, na teoria kantiana, desdobrase em uma ética do dever, segundo a qual "todo ser humano tem um direito legítimo ao respeito de seus semelhantes e está, por sua vez, obrigado a respeitar todos os demais"19, ao fundamento de que a humanidade possui uma dignidade intrínseca, "pois um ser humano não pode ser usado meramente como um meio por qualquer ser humano (quer por outros quer, inclusive, por si mesmo), mas deve sempre ser usado ao mesmo tempo como um fim"20.

Ainda hoje, as idéias expostas por Kant são consideradas, por muitos autores, como fundamento da noção de dignidade da pessoa humana. E, igualmente, no campo da bioética, como bem assenta Barreto, "a influência do kantismo na cultura filosófica e jurídica moderna [...] fez com que as idéias básicas do filósofo alemão terminassem como os parâmetros balizadores do debate bioético contemporâneo"21.

Entendemos, portanto, que a máxima da dignidade da pessoa humana possui função estruturante nas sociedades contemporâneas, em concepção analógica àquela aplicável ao Complexo de Édipo. Referido complexo, com a conseqüente proibição do incesto, funciona como regra estruturante de toda a sociedade - garantindo aos indivíduos a noção de família, ao possibilitar a estruturação mental, delimitando as fronteiras entre o desejo e a realidade, além de permitir simbolizar a noção de função paterna, materna, de irmão. Igualmente, a noção de dignidade da pessoa humana possui função estruturante das sociedades complexas que se organizam sob o poder estatal.

Partimos, ademais, da premissa de que o conteúdo da noção de dignidade da pessoa humana que possuímos no ocidente foi construído como um dado cultural, não sendo exclusivamente inerente à natureza humana, mas influenciado por valores consagrados por uma tradição ética judaico-cristã. Nesse sentido, anota Dworkin que cada sociedade possuiria seus próprios critérios de aferição de quais seriam as ações que atentariam contra a dignidade humana - os quais, outrossim, seriam passíveis de mutação histórica no âmbito de uma mesma cultura. Considerando-se, então, referida noção aberta

\footnotetext{
${ }^{19}$ KANT, 2003, p. 306.

${ }^{20}$ Idem, ibidem, p. 306.
} 
de dignidade da pessoa humana, é de se indagar sobre a eventual relativização históricocultural do conteúdo inserido no conceito, cujo preenchimento axiológico seria dinâmico.

Neste plano, emerge a teoria do relativismo cultural, que será devidamente abordada no curso desse trabalho, cuja relevância, para o presente tópico, reside em enunciar que as regras morais variam no tempo e no espaço e que cada sociedade, determinada por sua história e sua cultura, produz seu peculiar discurso axiológico. A dignidade da pessoa humana consistiria, destarte, em valor referencial com conteúdo valorativo composto por direitos historicamente considerados como sendo os mais fundamentais à humanidade.

Com referência aos direitos humanos, Hannah Arendt afirma, em sua obra As origens do totalitarismo, que não são um dado, mas um construído, uma invenção humana, em constante processo de construção e reconstrução. Norberto Bobbio, a seu turno, na obra $A$ era dos direitos, anota que "os direitos do homem, por mais fundamentais que sejam, são direitos históricos, ou seja, nascidos em certas circunstâncias, caracterizadas por lutas em defesa de novas liberdades contra velhos poderes, e nascidos de modo gradual, não todos de uma vez e nem de uma vez por todas" ${ }^{22}$. Desse modo, ainda que consideremos a noção de dignidade da pessoa humana como máxima irrenunciável, importa concluir que o seu conteúdo valorativo não pode ser desvinculado da evolução histórica.

Com efeito, não nos parece ser possível reduzir o conteúdo da dignidade da pessoa humana a uma fórmula fixa e universal. A busca de uma compreensão da extensão do conceito, relevante em razão da necessidade de maior precisão e segurança jurídica, somente é possível na análise do caso concreto, culturalmente determinado no tempo e espaço. Assim é que, considerando o pluralismo e a diversidade de valores protegidos nas sociedades democráticas, entendemos que a noção de dignidade da pessoa humana apresenta conteúdo valorativo aberto, em constante construção - irredutível a um conceito adstrito ao sistema do direito, pois ultrapassa as fronteiras do universo jurídico, para funcionar como seu parâmetro legitimador, com raízes na axiologia.

${ }^{21}$ BARRETO, Vicente de Paulo. A idéia de pessoa humana e os limites da bioética. In: Novos temas de biodireito e bioética. Renovar: Rio de Janeiro, 2003, p. 237.

${ }^{22}$ BOBBIO, Norberto. A era dos direitos. Rio de Janeiro: Campus, 1992, p. 05. 
$\mathrm{Na}$ modernidade, a dignidade da pessoa humana ganha natureza de regra estruturante de Estados Democráticos de Direito, pois inserida no âmbito da intersubjetividade e da pluralidade. Para Habermas, tal noção encontra-se estritamente vinculada à noção de simetria nas relações interpessoais, em que a recíproca consideração e respeito seriam premissas para um tratamento igualitário. Para Peter Häberle, referido por Sarlet (2006, p. 55), o reconhecimento recíproco da dignidade de cada ser-humano constitui uma ligação a todo o gênero humano, espécie de co-humanidade e sensação de pertencimento, devendo ser, portanto, compreendida a partir de uma perspectiva relacional e comunicativa, com a qual concordamos. Igualmente, Francis Fukuyama afirma que "partilhamos uma humanidade comum que permite a todo ser humano se comunicar potencialmente com todos os demais seres humanos no planeta e entrar numa relação moral com eles",23.

Partindo da noção relacional dos seres-humanos (do ser com os outros), e negando, assim, a concepção humana meramente individualista, igualmente entende Pérez Luño que a dignidade humana possui uma importante dimensão intersubjetiva ${ }^{24}$. Para Gonçalves Loureiro a proteção da dignidade da pessoa humana implica uma "obrigação geral de respeito pela pessoa" ${ }^{25}$, traduzida num feixe de deveres e direitos correlativos, de natureza não meramente instrumental, mas sim relativos a um conjunto de bens indispensáveis ao florescimento humano. E outrossim Kant, parece ter sugerido o caráter relacional da dignidade da pessoa humana, deduzindo desta premissa o dever de respeito aos outros. Em suas palavras:

\footnotetext{
é verdade que a humanidade poderia subsistir se ninguém contribuísse para a felicidade dos outros, contanto que também lhes não subtraísse nada intencionalmente; mas se cada qual se não esforçasse por contribuir na medida das suas forças para os fins de seus semelhantes, isso seria apenas uma concordância negativa e não positiva com a humanidade como um fim em si
}

\footnotetext{
${ }^{23}$ FUKUYAMA, Francis. Nosso futuro pós-humano: Consequências da Revolução da Biotecnologia. São Paulo: Rocco, 2003, p. 23.

${ }^{24}$ Cf. PÉREZ LUÑO, 1984, p. 318.

${ }^{25}$ GONÇALVES LOUREIRO, J.C. O direito à identidade genética do ser humano. In: Boletim da Faculdade de Direito da Universidade de Coimbra, 1999, p. 281.
} 
mesmo. Pois se um sujeito é um fim em si mesmo, os seus fins têm de ser quanto possível os meus, para aquela idéia poder exercer em mim toda a sua eficácia ${ }^{26}$.

$\mathrm{Na}$ dimensão jurídica, é de se concordar com Judith Martins-Costa, ao afirmar que a dignidade da pessoa humana constitui "valor fonte que anima e justifica a própria existência de um ordenamento jurídico"27. No mesmo sentido, Karl Larenz, ao discorrer sobre o princípio fundamental do direito, aponta para a noção de dignidade humana, a qual define como sendo o respeito recíproco: "o reconhecimento da dignidade pessoal do outro e, por conseguinte, da garantia da pessoa do outro em tudo o que concerne à sua existência exterior no mundo visível (vida, integridade física, saúde) e à sua existência como pessoa (liberdade, prestígio pessoal)"28.

Dessarte, mesmo nos ordenamentos jurídicos em que a noção de dignidade humana não foi expressamente consagrada na Carta Constitucional, é possível compreender que, enquanto elemento fundador de Estados que se propõem a proteger os direitos humanos consagrados no sistema internacional, está contida de forma implícita, como critério legitimador do poder estatal, porquanto o exercício desse poder e a organização do próprio Estado estariam, por conseqüência lógica, submetidos ao dever de efetivação da dignidade da pessoa humana ${ }^{29}$. O ser humano seria, portanto, a finalidade da atividade estatal e não o contrário.

De fato, a previsão constitucional de normas de direitos fundamentais (positivadoras de direitos humanos) constituiu barreira ao absolutismo e à tirania. Somente em circunstâncias excepcionais, o soberano pode restringir tais direitos - sem, contudo, furtar-se da aplicação da constituição. Tais barreiras, fundamentos do constitucionalismo moderno, legitimam o poder do Estado, pois sua observância alia a concretização de direitos considerados fundamentais para o desenvolvimento da pessoa humana à promessa estatal de segurança individual. Lembremos, então, que o respeito ao processo legislativo

\footnotetext{
${ }^{26}$ KANT, 2003, p. 136/137.

${ }^{27}$ MARTINS-COSTA, Judith. As interfaces entre o direito e a bioética. In: J. Clotet (org). Bioética, Porto Alegre: EDIPUCRS, 2005, p. 75.

${ }^{28}$ LARENZ, Karl. Derecho justo. Fundamentos de ética jurídica. Trad. Luis Diez-Picazo, Madrid: Civitas, 1985, p.57.
} 
não legitima um ato normativo que atente contra a dignidade da pessoa humana, uma vez que ele possui em seu cerne o gérmen de sua ilegitimidade - pois não é dado ao Estado o poder de legislar além dos limites do seu poder.

No Estado Democrático de Direito brasileiro, a dignidade da pessoa humana é reconhecida como sendo seu fundamento - segundo se depreende do artigo $1^{\circ}$, inciso III, da Constituição Federal -, inovando em relação às Cartas Políticas anteriores. Referida localização topológica sublinha, a seu turno, a importância concedida pelo legislador à referida máxima, a ser aplicada como referencial hermenêutico para a interpretação sistemática dos direitos humanos e do ordenamento jurídico brasileiro. Nas palavras de Sarlet:

\begin{abstract}
Impõe-se seja destacada a função instrumental integradora e hermenêutica do princípio, na medida em que este serve de parâmetro para aplicação, interpretação e integração não apenas dos direitos fundamentais e das demais normas constitucionais, mas de todo o ordenamento jurídico. De modo todo especial, o princípio da dignidade da pessoa humana - como, de resto, os demais princípios fundamentais insculpidos em nossa Carta Magna - acaba por servir de referencial inarredável no âmbito da indispensável hierarquização axiológica inerente ao processo hermenêutico-sistemático ${ }^{30}$.
\end{abstract}

Demais disso, outros capítulos da Constituição também previram a dignidade da pessoa humana como fundamentos da nossa República, como é o caso do art. 170, caput, ao estabelecer que a ordem econômica tem por objetivo assegurar a todos uma existência digna, do art. 227, que assegura à criança e ao adolescente o direito à dignidade, entre outros. Em outra perspectiva, a máxima da dignidade da pessoa humana encontra-se, igualmente, prevista no texto constitucional de inúmeros outros países, dentre os quais sublinhamos: a Alemanha (art. $1^{\text {o }}$, inc.I), a Espanha ${ }^{31}$ (preâmbulo e art. 10.1), a Grécia (art.

\footnotetext{
${ }^{29}$ Para Miranda, a unidade de sentido de uma constituição democrática repousa "na dignidade da pessoa humana, [...] ou seja, na concepção que faz da pessoa fundamento e fim da sociedade e do Estado". MIRANDA, Jorge. Manual de direito constitucional. Tomo IV, Coimbra: Coimbra, 1988, p. 166/167.

${ }^{30}$ SARLET, Ingo Wolfgang. Dimensões da dignidade. Porto Alegre: Livraria do Advogado, 2005, p. 79/80.

${ }^{31}$ No que concerne à constituição espanhola, ROMEO CASABONA anota que: "A dignidade da pessoa configura-se como o princípio informador e a raiz dos direitos básicos do homem, reconhecidos como fundamentais pela Constituição Espanhola, sobre os quais se projeta, e constitui seu filtro interpretativo, integrador e valorativo para os poderes públicos. Por eles, costuma-se reconhecer que a maior parte dos direitos fundamentais tem a dignidade da pessoa como conteúdo nucléico, o que explica a função informadora
} 
$2^{\circ}$, inc. I), a Irlanda (preâmbulo) e Portugal (art. $1^{\circ}$ ), que a consagram expressamente. Ainda, a Constituição da Itália faz referência à dignidade humana no art. $3^{\circ}$, em que, o qual, embora não mencione expressamente referida expressão, reconhece a todos os cidadãos a mesma dignidade social. Registre-se, ademais, que a Carta dos Direitos Fundamentais da União Européia, promulgada em Nice, em dezembro de 2000, expressamente define que "a dignidade do ser humano é inviolável. Deve ser respeitada e protegida (art. $1^{\circ}$ )". Resta claro, portanto, que o valor da dignidade da pessoa humana constitui princípio estruturante de todo o processo de positivação dos direitos humanos no âmbito do direito interno brasileiro e internacional ocidental.

Assim sendo, os direitos humanos devem ser enunciados e interpretados à luz do valor da dignidade da pessoa humana, o qual não possui natureza metafísica, mas estruturante e hermenêutica - o que impõe sua máxima realização e observância constante. Em outras palavras, exatamente por explicitarem o conteúdo axiológico da noção de dignidade da pessoa humana - em espécie de consubstancialidade parcial - é que os direitos humanos, considerados fundamentais em um contexto histórico e geograficamente determinado, devem ser realizados na maior medida possível. Isso significa que restrições a eles não negarão por completo seu conteúdo, porquanto devem preservar um mínimo ético irredutível $^{32}$, e que somente se justificarão quando tendentes à realização de outro direito que participe do conteúdo do valor da dignidade da pessoa humana. Destarte, entendo que, sem o respeito pela integridade do ser humano, pela sua liberdade e autodeterminação, pelo princípio da igualdade e demais direitos humanos definidos como fundamentais, não é possível falar-se em respeito pela dignidade da pessoa humana.

e interpretativa que se atribui aos mesmos". ROMEO CASABONA, Carlos Maria. Los desafíos jurídicos de las biotecnologías en el umbral del siglo veintuno. In: Biotecnologia, derecho y dignidad humana. Carlos María Romeo Casabona e Narciso Martinéz Morán (org.) Comares, 2004.

Tradução livre do texto: "La dignidad de la persona se configura como el principio informador y la raiz de los derechos básicos del hombre reconocidos como fundamentales por la Constitución española, sobre los que se proyecta y constituye su filtro interpretativo, integrador y valorativo de aquellos para los poderes públicos. Por ello suele reconocerse que la mayor parte de los derechos fundamentales presenta um contenido nucleico referido a la dignidad de la persona, lo que explica la función informadora e interpretativa que se atribuye sobre los mismos".

${ }^{32}$ Para Adorno a expressão mínimo ético irredutivel refere-se um núcleo duro de certos princípios, sem os quais a vida do homem em sociedade torna-se impossível. Ademais, ela "prétend donc signaler que le droit n'est pás um sytème clos, aseptique aux valeurs, mais qu'au contraire, il son fondement ultime dans l'ethique". ADORNO, Roberto. La bioethique et la dignité de la persone. Paris: PUF, 1997, p. 29. 
Em razão da concepção de que a máxima da dignidade da pessoa humana constitui critério legitimador do poder estatal, resta claro que nela inserem-se os direitos humanos protegidos no âmbito interno e internacional em suas múltiplas dimensões sejam elas defensivas ou prestacionais - e que, ademais, referida máxima possui uma dimensão comunitária que vincula, outrossim, os particulares ao dever de sua realização ${ }^{33}$, visando a garantir o pleno desenvolvimento de todas as pessoas.

No âmbito da bioética, a máxima da dignidade da pessoa humana constitui, igualmente, vetor legitimador do conteúdo de valores indispensáveis ao florescimento humano e, assim sendo, relaciona-se, diretamente, à dimensão axiológica dos direitos humanos. É, portanto, a noção de dignidade da pessoa humana que delimita os princípios cuja observância é indispensável no campo da medicina e da biotecnologia aplicada à vida, precisando, assim, limites à bioética e determinando que, tanto o direito como a ética, visem ao fim de proteger o seu núcleo valorativo.

Demais disso, tendo em vista os novos questionamentos suscitados pelos avanços da ciência no campo da genética e da biotecnologia, que, marcadamente, ultrapassam o âmbito interno dos Estados, a envolver toda a humanidade, os conceitos abertos de dignidade da pessoa humana e direitos humanos ganham pretensão de universalidade, com conteúdo normativo preenchido com base nos valores considerados fundamentais por cada cultura e naqueles que, no âmbito internacional, são "determinantes e caracterizadores dos direitos humanos, núcleo moral, político e jurídico do estado democrático de direito" 34 . Com efeito, é de se ver que a relação da bioética com os direitos humanos, protegidos no âmbito interno e pelo sistema internacional, resta definida, justamente, pela noção da dignidade da pessoa humana, vez que essa serve de parâmetro norteador da conduta do Estado em relação a cada indivíduo e desses entre si - o que, desde logo, justifica a relação estabelecida por este trabalho entre a bioética, os direitos humanos e a noção de dignidade da pessoa humana.

\footnotetext{
${ }^{33}$ Trata-se da chamada eficácia horizontal dos direitos humanos "em contraposição à mera eficácia externa, traduzida no dever universal de respeito que os cidadãos devem assumir em face dos direitos dos outros (enquanto que, nesta, tudo está em não interferir no exercício dos direitos de outros, na eficácia horizontal há relações bilaterais sobre as quais se projetam ou em que podem ser afectados especificamente certos e determinados direitos e garantias)", consoante explica Miranda (1988, p. 291).

${ }^{34}$ BARRETO, 2003, p. 222.
} 
Finalmente, é de se ver que, como bem assenta Perelman, "a noção de direitos humanos implica que eles sejam vinculados à qualidade do ser humano, titular de uma dignidade que lhe é própria e merece respeito enquanto sujeito moral livre, autônomo e responsável"35. Ou seja, na esteira do pensamento do filósofo belga, com o qual concordo, a dignidade humana é atributo da personalidade humana, e não do ser biológico.

2. Direitos humanos e bioética - Uma nocão aberta. As diversas dimensões dos direitos fundamentais ${ }^{36}$.

Em 1979, o francês Karel Vazak apresentou no Instituto Internacional de Direitos do Homem, em Estrasburgo, uma classificação baseada nas fases de reconhecimento dos direitos humanos, dividida por ele em três gerações, conforme as aspirações axiológicas a que deram identidade. Com o passar do tempo, novos direitos foram reconhecidos e a divisão tripartida deu lugar a propostas quaternárias.

No início do processo de positivação dos direitos fundamentais, refletia-se nos textos constitucionais a inspiração trazida à luz pelo direito natural, que exigia um nãoagir por parte do Estado, de modo a garantir a liberdade, a igualdade formal, a segurança, a propriedade e a resistência à opressão. Esta fase foi sucedida pelo reconhecimento de direitos de caráter social, inseridos na nova realidade produzida pela Segunda Revolução Industrial - o que resultou na proclamação de direitos econômicos e sociais, que demandam prestações positivas do Estado para que possam ser gozados concretamente. No entanto, a

\footnotetext{
${ }^{35}$ PERELMAN, Chaïm. Ética e direito. São Paulo: Martins Fontes, 1998.

${ }^{36}$ Tendo em vista a determinação histórica experimentada pelos direitos fundamentais, "não há como negar que o reconhecimento progressivo de novos direitos fundamentais tem o caráter de um processo cumulativo, de complementaridade, e não de alternância" (SARLET, 2005, p. 53). Em virtude disso, a preferência pela expressão "gerações de direitos" - mais comumente utilizada pela doutrina - poderia vir a sugerir a idéia de que uma geração é substituída por outra, o que refutamos e que ensejou a adoção da expressão "dimensões de direitos fundamentais".

Acrescentamos, ainda, a anotação que Sarlet (2005, p.54) faz ao comentar a posição de Weis, que "aponta a circunstância de que as classificações tradicionais - baseadas no critério da evolução histórica -, além de gerarem confusões de cunho conceitual, pecam por não zelarem pela correspondência entre as assim designadas gerações de direitos humanos e o processo histórico de nascimento e desenvolvimento destes direitos".
} 
evolução tecnológica, que alterou a realidade social, especialmente na segunda metade do século XX, deu margem a novas exigências, que, por sua vez, demandaram a consagração de outros direitos e a reformulação de antigos, a fim de que se atendesse a interesses coletivos e individuais e fossem previstos direitos de reprodução e de manipulação genética.

Importante considerar, nesse quadro das dimensões de direitos fundamentais, que o aparecimento de uma nova dimensão não exclui a outra já formada, pois se trata de um processo qualitativo e cumulativo, decorrente da necessidade histórica de serem satisfeitas novas necessidades do homem; processo que se deu no curso da história, da formação dos Estados modernos aos dias atuais, em virtude do progresso técnico, que gerou ciclos de desenvolvimento e crises econômicas, de novas ameaças à liberdade humana, ou simplesmente diante da alteração da realidade social.

Certos autores apontam, contemporaneamente, a formação de uma quarta dimensão de direitos fundamentais, na qual estariam inseridos os direitos à democracia $(\text { direta })^{37}$, à informação, ao pluralismo e os chamados “novos direitos”, originários das discussões bioéticas - que compreenderiam, entre outros, o direito a morrer com dignidade, o direito à mudança de sexo, etc. - que, de fato, ganharam espaço com o desenvolvimento das pesquisas biológicas e com a necessidade de garantia dos direitos do indivíduo diante das manipulações do patrimônio genético, conforme se vê da exposição de Durand (2003, p. 251):

Elaborados de início para proteger os cidadãos contra os abusos do estado, os
direitos humanos são cada vez mais utilizados no século XX para proteger a
pessoa humana contra os novos poderes suscitados pelos desenvolvimentos biomédicos, até mesmo tecnocientíficos. Está em jogo menos o cidadão abstrato que a pessoa concreta em seu corpo. Até recentemente, as ciências

\footnotetext{
37 Bonavides encarta, assim, na quarta dimensão de direitos fundamentais aqueles relativos à efetiva participação cidadã, o que alargaria as fronteiras democráticas. $\mathrm{O}$ direito à democracia é encarado de forma ampliada, como um direito de todo o gênero humano, e não apenas do cidadão, o que se dará por um elevado nível de democratização da sociedade. $C f$. BONAVIDES, Paulo. Teoria Constitucional da Democracia Participativa. Por um Direito Constitucional de Luta e Resistência. Por uma Nova Hermenêutica. Por uma Repolitização da Legitimidade. São Paulo: Malheiros, 2001.
} 
eram percebidas como estando do lado dos direitos humanos, servindo para fundamentá-los e conformtar a liberdade humana, mas quando elas se tornam tecnociências seus desenvolvimentos são contestados por esses mesmos direitos humanos.

Nas palavras de Bobbio (1992, p. 07):

já se apresentam novas exigências que só poderiam chamar-se de direitos de quarta geração, referentes aos efeitos cada vez mais traumáticos da pesquisa biológica, que permitirá manipulações do patrimônio genético de cada indivíduo. Quais os limites dessa possível (e cada vez mais certa no futuro) manipulação?

Nesse cenário, observa-se a necessidade de proteção de novos direitos fundamentais - advindos da nova realidade social criada pela globalização e pelos avanços conquistados pela ciência nos últimos anos, que teriam colocado em risco a preservação da dignidade da pessoa humana em suas novas dimensões ${ }^{38}$, sendo certo que o complexo processo histórico de permanente construção e reconstrução dos direitos fundamentais permite a este sistema aberto que possa, uma vez mais, adaptar-se e reconhecer novos direitos como sendo essenciais à proteção da dignidade da pessoa humana. Destarte, anota Sarlet (2005, p. 58) que:

Verifica-se, contudo, que boa parte destes direitos em franco processo de reinvindicação e desenvolvimento corresponde, na verdade, a faceta novas deduzidas do princípio da dignidade humana, encontrando-se intimamente vinculados (à exceção dos direitos de titularidade notadamente coletiva e difusa) à idéia da liberdade-autonomia e da proteção da vida e outros bens fundamentais contra ingerências por parte do Estado e dos particulares. Com efeito, cuida-se, no mais das vezes, da reivindicação de novas liberdades fundamentais, cujo reconhecimento se impõe em face dos impactos da sociedade industrial e técnica

\footnotetext{
${ }^{38}$ Quanto à proclamação de novos direitos fundamentais inseridos em um contexto de inumeráveis avanços tecnológicos, relevante sublinhar as palavras de Frosini: "En el tránsito de los antiguos derechos naturales a los nuevos derechos humanos se há evidenciado, pues, um cambio de perspeciva de 180 grados: los derechos racionales invocados por la filosofia se han transformado en derechos positivos incorporados a las leys estatales y a los tratados internacionales; los derechos individuales ligados al status del ciudadano han ampliado su ámbito de referencia a las formaciones sociales; de los derechos comprendidos en un catálogo cerrado y ahistórico se há passado a uma concepción abierta y progresiva de los mismos para adecuarla a las nuevas necesidades del hombre creador del mundo tecnológico." FROSINI, Vittorio. Los derechos humanos em la era tecnológica. In:PÉREZ LUÑO, Antonio Enrique, Derechos humanos y constitucionalismo ante el tercer milenio. Madrid: Marcial Pons, 1996, p. 94/95.
} 
deste final de século. Na sua essência e pela sua estrutura jurídica de direitos de cunho excludente e negativo, atuando como direitos de caráter preponderantemente defensivo, poderiam enquadrar-se, na verdade, na categoria dos direitos da primeira dimensão, evidenciando assim a permanente atualidade dos direitos de liberdade, ainda que com nova roupagem e adaptados às exigências do homem contemporâneo.

Com efeito, a legislação nacional e as Declarações de Direitos internacionais têm papel essencial e devem considerar a proteção ao patrimônio genético humano como um direito fundamental, que merece ser garantido e integrado na noção de dignidade da pessoa humana, considere-se ou não ele pertencente a uma quarta dimensão de direitos fundamentais. 


\section{CAPÍTULO II - A BIOÉTICA}

\section{O contexto de surgimento da bioética.}

A discussão bioética e a busca pelo estabelecimento de parâmetros éticos capazes de nortear a atuação de médicos e pesquisadores nasceram, justamente, em um cenário marcado pelo questionamento acerca dos benefícios trazidos pelos avanços científicos e do papel desempenhado pelo paciente e pelo sujeito de pesquisa, sendo que diversos fatos influíram diretamente neste movimento crítico: movimentos políticos, culturais e até mesmo alguns casos de abusos em pesquisas científicas noticiados pelos meios de comunicação estadunidenses.

De caráter político e cultural, destacamos, inicialmente, o movimento hippie, que ganhou palco nos anos sessenta nos Estados Unidos e que tinha como lema a busca pela liberdade, justiça e igualdade. Assim como os movimentos estudantis deflagrados nos países conhecidos como de Terceiro Mundo e o questionamento do establishment - do modelo vigente de conduta e sociedade -, o movimento hippie contribuiu para que surgisse um imaginário coletivo de culto à autonomia do indivíduo: busca por igualdade e "desconfiança no poder das grandes instituições" 39 .

É, por outro lado, certo que os movimentos de libertação política e econômica observados nos países da América latina e África, dentre os quais se inclui a Revolução cubana, foram fortemente influenciados pela ideologia marxista - ponto em que diferiram substancialmente dos movimentos sócio-culturais verificados nos Estados Unidos. Nesse país, as reivindicações trazidas pela sociedade articularam-se em torno da autonomia individual, sob o lema da liberdade sexual, de opinião e de crença demonstrando seu caráter eminentemente liberal. Esta constatação ganha relevo quando se sublinha a primazia concedida, por muitos autores, ao princípio da autonomia no que tange às discussões de caráter bioético, bem como pelos tribunais estadunidenses - que têm

\footnotetext{
${ }^{39}$ Cf. FERRER, Jorge José e ÁLVAREZ, Juan Carlos. Para fundamentar la bioética: Teorías y paradigmas teóricos em la bioética contemporânea. Madrid: Comillas, 2003, p. 68.
} 
fundado uma jurisprudência em assuntos de biodireito que se baseia no respeito quase absoluto à autonomia.

Contribuíram para a reafirmação da idéia de igualdade as lutas travadas nos Estados Unidos, durante os anos sessenta e princípios dos anos setenta, em favor da igualdade racial, merecendo destaque a figura de Martin Luther King e a aprovação de duas leis que puseram fim, do ponto de vista jurídico, à discriminação racial: Civil Rights Act, em 1964, e a lei sobre os direitos eleitorais das minorias, em 1965. Ferrer e Álvarez (2003, p. 68) destacam, ainda, as políticas de discriminação positiva, conhecidas como affirmative actions e a determinação de integração racial das escolas como elementos propulsores da busca de realização de uma igualdade substancial.

Os anos sessenta foram, assim, marcados pela crise das instituições sociais norte- americanas. Os movimentos hippies constituíram expressão marcante da contestação social à instituição familiar. O modelo de escola vigente nos Estados Unidos também sofreu alteração relevante com a integração racial promovida. A igreja, por sua vez, viveu o que se chamou de crise posconciliar e a confiança depositada no Estado restou abalada por conta da Guerra do Vietnan e do caso Watergate. Neste cenário de negação da autoridade vigente e valorização da ampla autonomia e igualdade, a relação estabelecida entre médicos e pacientes também foi questionada. Além da influência inegável de todos os acontecimentos de ordem política e cultural que marcaram a década de sessenta, a publicação de casos de abusos cometidos por pesquisadores nos Estados Unidos fez ressurgir a imagem das atrocidades cometidas pelos cientistas nazistas durante a Segunda Guerra Mundial. Impulsionou, portanto, a busca pelo estabelecimento de diretrizes éticas que valorizassem a autonomia do indivíduo.

Não menos importantes para a bioética, foram os avanços alcançados nos anos sessenta no que atine ao desenvolvimento de novos medicamentos e técnicas médicas - que influenciaram de forma relevante a medicina e as relações humanas como um todo. Destacamos o surgimento da pílula contraceptiva, da diálise renal, a ampliação do diagnóstico pré-natal, a consolidação do paradigma hospitalar, que transferiu a morte domiciliar para dentro dos hospitais e, principalmente, a realização do primeiro transplante de órgãos em seres humanos - ocorrido na África do Sul, em 1967 -, que constituiu o 
primeiro precedente para a alteração da noção de morte cardio-respiratória para morte cerebral, porquanto "a retirada de órgãos, imediatamente após o óbito, exigia uma nova definição de critérios de determinação da morte" ${ }^{\text {40 }}$.

\section{Abusos na investigação científica.}

A exposição, através dos julgamentos de Nuremberg, dos horrores cometidos pelos nazistas, durante a Segunda Guerra, nas pesquisas em seres humanos, culminou no anseio geral da humanidade de que aquilo não se repetisse. Nesse sentido, Ferrer e Álvarez (2003, p. 71) anotam que "o chamado Código de Nuremberg (1947) abriu caminho para a formulação de normas mais precisas para proteger a integridade dos seres humanos em experimentações biomédicas”. Durand (2003, p. 40), por sua vez, sublinha, referindo-se ao Código de Nuremberg, que "ele foi o primeiro a suscitar uma conscientização sobre os perigos dos progressos da ciência desejados a qualquer custo", porém completa que nos Estados Unidos havia a noção de que tais atrocidades científicas não ocorreriam, de que se tratava de uma atitude nazista.

Assim, a publicação, através da imprensa estadunidense e internacional, de casos de indiscutível abuso ${ }^{41}$ - cometidos por médicos e pesquisadores daquele país chocaram a população norte-americana e ocidental em geral. Rememoraram as imagens dos campos de concentração nazistas e impeliram a opinião pública norte-americana a

\footnotetext{
${ }^{40}$ ROY, David, p. 12, apud DURAND, 2003, p. 29.

41 No que concerne a estes abusos, Durand (2003, p. 40/41) traz relato relevante: "O primeiro desses escândalos foi o nascimento, em 1962, de várias crianças afetadas por más-formações congênitas importantes, como falta de membros, seqüelas da ingestão por parte da mãe, durante a gravidez, de um medicamento chamado talidomina. Esse medicamento, que ainda não havia sido aprovado pela FDA americana, fora testado algumas vezes em pessoas que não sabiam estar participando de uma pesquisa.[...]

O segundo acontecimento foi a publicação de um artigo assinado por um médico americano [...]. Professor de anestesia em Harvard, ele escreveu um curto artigo no qual repertoriava vinte e duas experiências que considerava não-éticas. Isso se devia, em sua opinião, à ausência de consentimento das pessoas que eram objeto de experiência e uma má avaliação dos riscos em relação aos benefícios. [...] Depois disso, outros escândalos também foram desvelados nos estados Unidos. O caso Tuskegee é apresentado ao público em 1972. essa pesquisa consistia em observar a progressão da sífilis em um grupo de mais de quatrocentos negros atingidos por essa doença e deixados sem tratamento, alguns deles durante mais ou menos quarenta anos, enquanto a eficácia da penicilina para o tratamento já era conhecida”.
} 
pressionar o governo para que fossem adotadas medidas preventivas, que garantissem maior ética nas pesquisas.

Em 12 de julho de 1974 foi, então, aprovada uma lei, conhecida como National Research Act, que criou a primeira comissão nacional, cuja atribuição seria estudar as questões éticas envolvidas no campo da biomedicina e da investigação científica, especialmente no que concerne à pesquisa em seres humanos: National Commission for the Protection of Human Subjects of Biomedical and Behavioral Research. A principal incumbência desta comissão consistiu na determinação de princípios éticos fundamentais que orientassem a investigação científica - e a promulgação de diretrizes concretas que guiassem os pesquisadores para a real efetivação desses princípios, conforme destacam Ferrer e Álvarez (2003, p.74). Os resultados do trabalho da Comissão foram publicados em 1979 através do que se chamou Informe Belmonte, com a apresentação de três princípios fundamentais e gerais que deveriam nortear as questões de ordem bioética: autonomia, beneficência e justiça. O princípio da autonomia enfatiza a autodeterminação do ser humano e sua capacidade e direito para decidir sobre seu destino - o que atuaria como parâmetro para escolhas terapêuticas e relativas à utilização do corpo humano. O princípio da beneficência revigora o núcleo do juramento hipocrático e da máxima "non nocere". O princípio da justiça, a seu turno, traduz a noção moderna de igualdade substancial a ser perseguida em Estados Democráticos de Direito.

Houve, ainda, a formação de uma segunda Comissão Nacional: The President's Comission for the study of Ethical Problems in medicine and Biomedical and Behavioral Research), que no período de 1980 a 1983 produziu importantes documentos para a regulamentação do procedimento de investigação científica, baseando-se, contudo, nos princípios declarados no Informe Belmonte.

Ganha, então, luz o principialismo, consagrado pelos autores Beauchamp y Childress $^{42}$, que desenvolveram a aplicação de cada um dos princípios enunciados pelo Informe Belmonte em sua obra Principles of Biomedical Ethics, cuja primeira edição foi publicada ainda em 1979. 


\section{Os princípios da bioética.}

O principialismo consiste na proposta de fundamentação da bioética que exerceu mais difusão e influência sobre esta disciplina. Se, por um lado, a imagem das experiências nazistas com seres humanos ainda se faz presente - impondo restrições éticas às pesquisas científicas de modo a garantir a preservação da dignidade do ser-humano -, a possibilidade de manipulação da vida humana, em virtude do progresso científico e tecnológico, ressaltou outro viés de sua fragilidade. Deste processo de conscientização, que abrangeu a sociedade como um todo, o que inclui a comunidade científica, decorreu a declaração de princípios fundadores da bioética.

A teoria principialista tem como fundamento a ética do dever: contraposta à chamada ética das virtudes, a qual, baseada em Aristóteles, ressaltava a vocação do agir moral virtuoso. Immanuel Kant propôs as bases de referida ética, sustentando que o agir humano segundo os princípios da moralidade, fundados no imperativo categórico, resultaria em um comportamento moral, como bem sublinha Barreto ${ }^{43}$. Todavia, é certo que a medicina ocidental desenvolveu-se sobre bases de uma ética da virtude, claramente ilustrada pelo juramento a Hipócrates, valorizando o agir virtuoso do médico, que mesmo diante de contextos complexos e contingentes deveria considerar a atitude mais beneficente e que visasse à cura do paciente. Como bem sublinha Hottois ${ }^{44}$, era dever do médico restabelecer o equilíbrio rompido pela doença, o que seria alcançado através da escolha virtuosa feita pelo médico.

O juramento de Hipócrates "parece ter nascido nos meios pitagóricos e servia para agrupar médicos que queriam se distinguir dos outros por sua competência e por seus costumes" ${ }^{45}$. Ele centrava-se "no dever de beneficência do médico" ${ }^{46}$.

\footnotetext{
42 BEAUCHAMP, Tom L. e CHILDRESS, Tom. Princípios de ética biomédica. Trad: Luciana Pudenzi. São Paulo: Loyola, 2002.

${ }^{43}$ BARRETO, Vicente de Paulo. As relações da bioética com o biodireito. In: BARRETO, Vicente de Paulo e BARBOZA, Heloisa Helena (org). Temas de biodireito e bioética. Rio de Janeiro: Renovar, 2001, p. 50.

${ }^{44}$ HOTTOIS, Gilbert. Essais de philosophie bioéthique et biopolitique. Paris: J. Vrin, 1999, p. 09.

${ }^{45}$ DURAND, 2003, p. 92.

${ }^{46}$ Idem, ibidem, p. 95.
} 
A definição de uma teoria ética da virtude, contudo, mostrou-se incapaz de definir parâmetros de conduta eficazes para solucionar casos concretos suscitados pelos avanços tecnológicos e científicos, nos quais o agir do médico, fundamentado em suas virtudes individuais restou insuficiente para garantir uma escolha moralmente aceita em contextos culturais plurais. Ganhou importância, então, a teoria ética baseada no dever, que buscou, no campo bioético, estabelecer princípios que pudessem ser aplicados de forma geral por médicos e cientistas e que tivessem como núcleo valores morais fundamentais à civilização ocidental. Exatamente em tais valores fundam-se os princípios da bioética - que determinam nortes às difíceis escolhas a serem tomadas pelos profissionais da área da medicina e outras disciplinas relativas à vida.

Ademais, a noção de que o Estado deveria intervir nas áreas da saúde, fosse para garantir a efetivação de direitos sociais, ou para simplesmente assegurar o respeito à pessoa humana através dos direitos individuais, contribuiu para que o principialismo se consolidasse. Seria inaceitável que o Estado exercesse um controle sobre a atividade médica ou científica baseando-se em julgamentos segundo a virtude individual, sem qualquer parâmetro objetivo. Barreto (2001, p. 53) ressalta que se tornou, então, necessário “o estabelecimento de um sistema de normas que regulassem o exercício da profissão e da pesquisa, independente das virtudes pessoais de cada indivíduo".

As ações humanas não são sempre boas, nem sempre más, sendo que atitudes destrutivas são inerentes ao ser humano, cuja personalidade se funda diante da dicotomia amor e ódio ${ }^{47}$. Dessa forma, novas descobertas científicas sempre poderão ser utilizadas para o progresso da humanidade, garantia de melhor qualidade de vida, ou se transformar em armas contra os homens. Essa contradição acompanha a história humana, desde o momento em que nos tornamos capazes de transformar a natureza, e tem gerado maiores anseios diante da possibilidade de dominação dos processos de reprodução e

\footnotetext{
${ }^{47}$ Cohen e Ferraz lecionam que "no que toca à concepção de uma natureza humana, Freud sempre insistiu em dizer que ela nada teria de 'boa'. A partir de uma outra ótica, menos moralista, podemos dizer que ela não é nem boa nem má. Por esse motivo podemos dizer que a grande contribuição que Freud deu à ética foi a da dissolução do preconceito de que existem alguns seres humanos bons e outros maus". COHEN, Cláudio e FERRAZ, Flávio Carvalho. Direitos humanos ou ética das relações. In: SEGRE, Marco e COHEN, Cláudio. Bioética. São Paulo: EDUSP, 2002, p. 73.
} 
alteração genética humana, uma vez que significam a transformação da própria espécie por si mesma.

A bioética, sob o paradigma principialista, estabelece, dessarte, limites ainda que gerais e alteráveis no tempo e espaço - para a atuação humana e o progresso da ciência. Funcionam como horizonte para a definição de normas jurídicas que os concretizem e regulem as atividades profissionais que tratem da vida humana, porquanto os príncipios são determinados pelos grandes valores éticos de uma sociedade, os quais constituem fonte de direitos ainda não formulados. Partimos, então, da premissa de que os valores considerados como fundamentais por uma determinada sociedade são históricogeograficamente determináveis, não contendo caráter absoluto ou universal ${ }^{48}$. Constituem o substrato moral do qual surgem os princípios éticos e as normas jurídicas em geral. Seu caráter abrangente extrapola o âmbito jurídico e positivo e o reconhecimento dos valores presentes pode ensejar a responsabilização daqueles que os desrespeitam, como ocorreu no julgamento de Nuremberg.

Barreto (2001, p. 65) anota, neste sentido, que:

A construção de uma racionalização que procure justificar universalmente alguns direitos e a conseqüente responsabilização por atos que infrinjam essas normas, supõe o reconhecimento de que existem para além do direito positivo um conjunto de valores que devem justificar-se e sobre os quais podem ser formulados direitos, ainda não considerados pelo direito positivo.

Em Estados Democráticos de Direito os princípios definidores de direitos fundamentais têm a função de preencher o conteúdo do princípio estruturante da ordem constitucional: a dignidade da pessoa humana, sobre o qual discorreremos com maior profundidade no Capítulo IV. "Neste contexto, é que o direito deve procurar na argumentação moral os fundamentos para normas que controlem, em função do respeito ao princípio constitucional, as novas relações sociais surgidas no seio da civilização tecno-

\footnotetext{
${ }^{48}$ Interessante anotar observação de Barreto (2001, p. 66) quanto ao caráter não absoluto dos direitos fundamentais: "O indivíduo no contexto das novas tecnologias genéticas sofre com a intervenção do Estado, retirando a solução dos problemas suscitados pela nova biologia, do âmbito restrito da autonomia individual. Por outro lado, a desindividualização da pessoa humana na contemporaneidade, face à medicina e suas
} 
científica da contemporaneidade", como bem afirma Barreto (2001, p. 74). Os princípios da bioética representaram a busca de construção de uma ética normativa prática capaz de orientar médicos e cientistas sobre o que seria eticamente razoável diante dos novos questionamentos suscitados pelos avanços da ciência, especialmente no campo da genética - que fizeram surgir dúvidas até então inexistentes. Basearam-se, assim, nos valores tradicionalmente aceitos pela comunidade médica e científica e têm, ainda hoje, norteado a atuação de conselhos de medicina, comitês de ética de hospitais e institutos de pesquisa.

\subsection{Princípio da autonomia.}

Da análise etimológica do termo autonomia depreendemos o significado de que é autônomo aquele que define sua própria lei. Historicamente, primeiro foi aplicado aos povos e, posteriomente, extendido à esfera pessoal dos indivíduos. A autonomia decorre da racionalidade humana, que garante a capacidade pessoal de eleger um projeto de vida, os meios de realizá-lo e efetuar escolhas diante de possibilidades, avaliando as consequências dos seus atos. É pressuposto necessário para que se possa afirmar uma atitude ética - que concede liberdade de reflexão e atuação ao indivíduo. Caso não the fosse concedida esta autonomia, o ser humano seria como um joguete cujas ações seriam pré-determinadas, não sendo possível, assim, responsabilizá-lo por elas. Assim é que a autonomia constitui premissa fundamental de legitimidade dos sistemas morais e jurídicos - que se baseiam no dever e na responsabilidade - concedendo um âmbito de liberdade aos indivíduos, em certa medida já condicionados por fatores genéticos, sociais, culturais, etc.

Em outras palavras, entendemos que o princípio da autonomia individual seja necessário mas que não faça sentido falar-se em autonomia absoluta, seja porque não se trata de um princípio hegemônico, ou porque não é possível que alguém possa ser completamente autônomo e livre, pois o processo de humanização se dá justamente com a apropriação de valores culturais e sociais. Cohen afirma que "a autonomia é um atributo da nossa humanização e que a sociedade nos reconhece. Desse modo, a autonomia nunca será

tecnologias, torna-se mais evidente quando consideramos o fato de que os direitos individuais não são absolutos, pois eles convivem com direitos, também individuais, de outras pessoas". 
total, para qualquer ato social, e nem será permanente; ou seja, não podemos afirmar que ela, uma vez alcançada, não poderá ser mais questionada"49.

Cumpre, ainda, destacar que a importância concedida ao princípio da autonomia insere-se na relação modernamente estabelecida entre direito e moral no ocidente - baseada na noção de liberdade, conforme exposto por Stuart Mill em sua obra On Liberty. O valor liberdade constitui premissa fundamental para que sociedades liberais possam se estruturar. O próprio Estado moderno deita suas raízes no reconhecimento da liberdade individual, que somente pode ser restringida pela lei e em favor da proteção da liberdade dos demais.

Finalmente, para que uma pessoa seja considerada autônoma devemos considerar sua capacidade de determinação e analisar o grau de influência exercido pelo ambiente externo a ela, bem como pelas suas limitações pessoais, de modo a verificar se o indivíduo é capaz ou não de fazer escolhas genuínas, vez que mesmo as pessoas consideradas capazes para a prática da maioria dos atos podem, em certos contextos, tomar decisões não autônomas: por ignorância, depressão, desespero, ou outros fatores.

Ferrer e Álvarez (2003, p. 127) expõem que para que uma ação possa ser considerada autônoma o agente moral deve agir: 1) intencionalmente, 2) com compreensão e 3) sem influências externas que determinem ou controlem sua ação. Baseiam-se na obra de Beauchamp e Childress, os quais sublinham que a intencionalidade não admite níveis: existe ou não existe. Porém, no que tange à compreensão e à liberdade em relação às influências externas, elas poderiam ser mais ou menos autônomas. Concordamos com essa posição, porquanto entendemos que nenhum agente possa ser considerado completamente livre de qualquer influência externa e que, em muitos casos, a completa compreensão de um procedimento médico ou científico é uma utopia, ao ser buscada em leigos. É necessário, assim, que se possa considerar que o sujeito seja autônomo em razão de uma liberdade e compreensão susbstancial - o que certamente não é facilmente avaliável.

\footnotetext{
${ }^{49}$ COHEN, Cláudio. Bioética: pesquisa e deficiência. In: SEGRE, Marco e COHEN, Cláudio. Bioética. São Paulo: EDUSP, 2002, p. 73.
} 
Além disso, o respeito à autonomia impõe a exigência de que se possibilite ao agente ter suas próprias opiniões, a fim de que possa fazer suas próprias opções e agir de acordo com seus valores e crenças pessoais. Contudo, ele só será capaz de fazer opções autônomas se lhe for revelada a informação necessária para que possa efetivar escolhas. Impõe-se, assim, uma atuação positiva de médicos e cientistas - o que revela tal dimensão, em certa medida ativa, do direito à liberdade. A informação revelada pelos profissionais deve ser clara e suficiente para que o indivíduo possa avaliar suas possibilidades de escolha, de modo a ser capaz de consentir com fundamento em uma decisão consciente e informada. Destarte, exige-se que se comunique a informação de forma que o paciente possa entendê-la, considerando-se suas limitações sociais, culturais ou decorrentes de sua debilidade emocional, em virtude da doença ${ }^{50}$. Demais disso, a capacidade do indivíduo para exercer a sua autonomia deve ser avaliada no que concerne a decisões pontuais, não sendo aplicável a disposição geral contida no Código Civil brasileiro. Sujeitos considerados capazes pela lei civil podem, em certos casos, tornarem-se momentaneamente incapazes, ou, por outro lado, aqueles que a lei considera absolutamente incapazes para os atos da vida civil podem já saber escolher entre terapêuticas ou decidir sobre seu próprio corpo.

Reafirmamos, por fim, mais uma vez, que entendemos, assim como Ferrer e Álvarez (2003, p. 129), que a autonomia não constitui um princípio hegemônico e nem mesmo superior aos outros - sendo que nem sempre prevalecerá quando colidir com os outros princípios da bioética ou amplamente definidores de direitos fundamentais. Sendo o indivíduo incapaz de proferir uma decisão autônoma, poderá, então, justificar-se, no caso concreto, uma intervenção paternalista - e a primazia condicionada do princípio da beneficência. Cabral filia-se a este entendimento ao sublinhar que

\footnotetext{
Não sendo a autonomia um valor absoluto, também o princípio que impõe o seu respeito não é incondicional; pode, antes, ser legitimamente limitado pelo respeito por outros valores, assegurados por outros princípios, nomeadamente o da beneficência ou o de justiça. Por isso falamos da legítima autonomia. ${ }^{51}$
}

\footnotetext{
${ }^{50}$ No que concerne à avaliação desta capacidade, Ferrer e Álvarez (2003, p. 123) entendem que os critérios necessários para determinar se um sujeito é substancialmente autônomo podem variar de acordo com o contexto em que insere a compreensão.

51 CABRAL, Roque. Os princípios de autonomia, beneficência não maleficência e justiça. In: Bioética. Coord. Luís Archer (et.). Lisboa: Verbo, 1996, p.53/54.
} 
Beauchamp e Childress (2002, p. 145) também afirmam que "tanto o princípio à autonomia como suas especificações são prima facie não absolutos”, porém, é certo que concedem a ele papel central em sua obra, restando implícita a preponderância que lhe é dada e a herança liberal que trazem consigo.

\subsection{Princípio da beneficência e da não-maleficência.}

O principio da beneficência define a exigência de que se promovam ações benéficas aos outros seres humanos. Beauchamp e Childress (2002, p. 282) entendem que a observância deste princípio depende de dois sub-princípios: a beneficência positiva e a utilidade. O primeiro determinaria o dever de agir beneficamente em relação aos demais homens e o segundo afirmaria a necessidade de que os benefícios superassem os benefícios causados pela suposta ação beneficente.

O princípio da não-maleficência define o dever de não se causar danos intencionais aos demais indivíduos. Constitui uma das bases em que se funda a ética médica, segundo a obrigação "primum non nocere", abraçada por Hipócrates. Ferrer e Álvarez (2003, p. 130/131), seguindo Diego Gracia, consideram que neste princípio se fundamente todo o sistema moral humano - o que ilustram citando Santo Tomás de Aquino, o qual propôs que o primeiro preceito da lei moral seria "fazer o bem e evitar o mal"52. Todavia, Beauchamp e Childress (2002, p. 284) não concedem tal prioridade ao princípio da não-maleficência, afirmando que "muitas regras de beneficência obrigatória constituem uma parte importante da moralidade".

\subsection{Princípio da justica.}

Ferrer e Álvarez (2003, p. 76), referindo-se a Callahan, ressaltam que a fundação da revista Philosophy and Public Affairs (1970) e a publicação da importante obra de John Rawls A Theory of Justice (1971) marcaram o início de uma "nova era na filosofia

\footnotetext{
${ }^{52} C f$. Tomás de Aquino. Summa Theologica, I-II q. 94, a.2.
} 
moral norte-americana", em que as preocupações com os problemas econômico-sociais ganhariam espaço no âmbito filosófico e de definição de direitos fundamentais à pessoa humana.

Consideramos, contudo, como marcos históricos na definição de direitos fundamentais de ordem social documentos bem anteriores à década de 1970, como a Constituição mexicana de 1917 ou a Carta Magna alemã de 1919. Todavia, é de se concordar que, de fato, foi diante do substrato ideológico e cultural criado pela década de sessenta que os ideais de igualdade material e liberdade fática puderam se desenvolver especialmente nos Estados Unidos. O resultado foi a proclamação, em 1966, no âmbito internacional, dos Pactos sobre direitos civis e políticos e econômicos, sociais e culturais que, de forma muito ilustrativa, demonstraram a alteração do paradigma de atuação do Estado diante do dever de proteção da pessoa humana. Esta segunda dimensão de direitos fundamentais compôs-se dos direitos sociais, culturais e econômicos, bem como dos direitos coletivos ou de coletividades que, pela sua natureza, demandam do Estado prestações positivas, concretas, as quais nem sempre são exeqüíveis, por carência ou limitação essencial de meios e recursos estatais, ou pela necessidade da implementação de políticas públicas para sua consecução. O princípio da justiça assumiu, então - neste cenário em que se faziam presentes os direitos sociais - novos contornos e nova abrangência, que em muito expandiram o ideal de justiça aristotélico, passando a considerar a noção de igualdade substancial como constitutivo da justiça, conforme nos lembra Hossne $^{53}$.

No campo biomédico, o Estado passou a intervir na saúde, que deixou de ser uma questão privada para se tornar um problema público. E, justamente por isso, as discussões bioéticas transpuseram o âmbito individual, alcançando as dimensões sociais “que ultrapassam as relações médico-pacientes e envolvem decisões de caráter moral e político que afetam à sociedade, atual e futura" ${ }^{, 54}$. Diante de tal relevância, a justiça foi considerada por Beauchamp e Childress como um dos pilares da bioética, o que resulta da especial importância que passou a ser dada pela sociedade americana às questões

\footnotetext{
${ }^{53}$ HOSSNE, William Saad. Competência do médico. In: SEGRE, Marco e COHEN, Cláudio. Bioética. São Paulo: EDUSP, 2002, p. 112.
} 
envolvendo alocação de recursos - tema que hoje, mais do que nunca, tem sido debatido em todos os países.

Anotamos, enfim, que o princípio da justiça, bem como os outros princípios, não é absoluto. E, nesse sentido, Durand (2003, p. 209) afirma que:

\begin{abstract}
Não existe, portanto, uma justiça absoluta, capaz de fornecer uma referência universal que transcenda as divergências particulares. Não há concepção transcendente da justiça. Milton Fisk explica claramente que todo consenso obtido e defendido se resumiria apesar de tudo ao simples reflexo do ponto de vista de um grupo. Se não fosse esse o caso, esse consenso teria saído, de qualquer modo, de uma sociedade historicamente determinada, à qual se limitaria seu valor.
\end{abstract}

\title{
4. Questões envolvendo o principialismo.
}

Exposto o paradigma principialista, é de se sublinhar que os princípios propostos por Childress e Beauchamp, considerados bases da bioética, não esgotam os valores considerados fundamentais pela humanidade - o que, inclusive, seria impossível de ser alcançado, uma vez que consideramos que os valores sejam inexauríveis.

Todavia, os quatro princípios enunciados constituem, de fato, importantes pilares da vida moral ocidental contemporânea: essenciais para a reflexão dos temas bioéticos, não se devendo, por outro lado, desconsiderar-se outros princípios como a vida, igualdade, a privacidade, etc. - que assim como a autonomia, beneficência, nãomaleficência e justiça preenchem o conteúdo da noção de dignidade humana, que deve ser sempre respeitada por médicos e cientistas. Divergimos, assim, de Ferrer e Álvares (2003, p. 154) quando dizem que os princípios enunciados por Childress e Beauchamp seriam "os pontos cardeais da vida moral no âmbito da bioética”.

No entanto, concordamos com os autores em referência no que tange à afirmação de que tais princípios não teriam sido inventados pelos redatores da obra

\footnotetext{
${ }^{54}$ BARRETO, 2001, p. 67.
} 
Principles of Biomedical Ethics ou mesmo por aqueles do Informe Belmonte. Conforme já expusemos, os princípios abraçados pela bioética resultaram da evolução da tradição ética ocidental: fortemente influenciada pela filosofia grega e pelos valores cristãos. Assim, resta claro que tais princípios consagram uma concepção ética determinada: ocidental, e poderão ser rejeitados por agentes que não participem desta tradição ética e dos valores que deram origem a esses quatro princípios ${ }^{55}$.

Visando a identificar as bases filosóficas do principialismo, Ferrer e Álvarez (2003,p. 154/155) partem da tradição grega para destacar as obras de Platão e Aristóteles, que já na idade antiga teriam enfrentado a questão da justiça. Os princípios de beneficência e não-maleficência, a seu turno, teriam constituído as bases da ética médica hipocrática e cristã, ilustrada no pensamento de Santo Tomás de Aquino. O respeito pela autonomia de cada ser humano seria o princípio norteador da moral moderna, presente no pensamento filosófico de Locke e representado no imperativo categórico de Kant, os quais teriam proposto as bases das Declarações modernas de direitos humanos. Ademais, o princípio da autonomia pode ser considerado fundamental à consolidação do pensamento liberal, consagrado nas revoluções do século XVIII.

Herdamos, portanto, um horizonte ético fundado, em grande medida, em valores traduzidos por estes quatro princípios - que se fazem presentes na cultura ocidental e determinam nossa opção política, econômica e social. A democracia liberal moderna, por exemplo, possui seus alicerces no princípio da autonomia, sendo incapaz de subsistir sem ela. Por outro lado, contudo, um exame mais profundo da própria democracia definiria, outrossim, que esta se legitima por garantir os direitos fundamentais, o conjunto de direitos que são considerados hoje como sendo essenciais à preservação da dignidade humana - os quais ultrapassam os limites da autonomia individual para abraçar as noções de igualdade substancial, liberdade fática e participação política, por exemplo.

Como sublinha Fagot-Largeault, o conjunto de direitos fundamentais consagrados na Declaração Universal de Direitos Humanos é produto da história da

\footnotetext{
55 Suas origens são expostas por Ferrer e Alvarez (2003), do que se observa a ausência de bases filosóficas que não sejam ocidentais e, por outro lado, ilustra-se o entendimento de que se trata de apenas uma das muitas possibilidades de construção de parâmetros éticos de conduta humana.
} 
humanidade - de uma história ocidental, sobre a qual influíram diversas famílias culturais , de um processo de aprendizado constante e doloroso, como o que se deu em Nuremberg, em $1947^{56}$. Tais direitos foram, de fato, consagrados paulatinamente, sobre bases morais diversas e tradições filosóficas conflitantes em grande medida. Alteraram-se: alguns foram restringidos e outros se tornaram mais abrangentes, compatibilizaram-se entre si, como se um acordo tácido entre eles houvesse sido buscado - espécie de consenso social ${ }^{57}$.

Além disso, a positivação constitucional de princípios definidores de direitos fundamentais, bem como a previsão de garantia de sua proteção devem ser destacadas. Constituem as bases legitimadoras de um Estado Democrático de Direito e devem nortear a atuação legislativa, a fỉm de buscar sua efetivação e, assim, a realização do conteúdo valorativo da dignidade humana. Dessa forma, nenhuma atuação bioética ou no campo jurídico deverá olvidar-se do mandamento da máxima realização desses princípios. Nesse sentido, Barboza sublinha que:

não há em nossa Constituição um capítulo dedicado ou pertinente à Bioética ou ao Biodireito. $\mathrm{Na}$ verdade, todas as disposições constitucionais relativas à vida humana, sua preservação e qualidade, estão imbricadas com o Biodireito, que não se restringe às questões atinentes à saúde, ao meio ambiente ou à tecnologia ${ }^{58}$.

E caso se considerasse cada um dos princípios consagrados na bioética como absolutos, a validade dos demais princípios seria esvaziada. A beneficência pode transformar-se em paternalismo forte e desrespeitar a autonomia necessária ao ser humano,

\footnotetext{
${ }^{56}$ FAGOT-LARGEAULT, Anne. "La réflexion philosophique em bioéthique". In: Bioéthique méthodes et fondements (Les cahiers scientifiques, 66), 1989, p. 6/7 apud DURAND, 2003, p. 151.

${ }^{57}$ Completa, ainda, a autora: "O princípio do respeito à pessoa em sua autonomia formou-se na tradição judeu-cristã, inspirou o nascimento das democracias modernas, encontrou sua expressão filosófica mais elaborada em Kant em uma moral do dever, da obrigação incondicional de respeitar em seu próximo o sujeito livre, a fonte da moralidade. O princípio de que é preciso maximizar o bem minimizando o mal tem origens, sem dúvida, mais pagãs que cristãs; ele encontrou sua formulação filosófica no utilitarismo, no qual o direito se funda não na obrigação e sim no desejo de não frustrar inutilmente a necessidade de desenvolvimento do ser vivo. O princípio de busca do verdadeiro talvez remeta ao prodígio grego, à reflexão sobre os fins do ser humano, à idéia de que o fim humano mais alto está no conhecimento. O fato é que essas fontes filosóficas são heterogêneas, até mesmo incompatíveis. Lembremos com que vigor Kant rejeitava a idéia utilitarista como fundamento da moralidade. Mas os princípios estão aqui separados de suas origens, sobre as quais se silenciou, como que por um acordo tácito que lhes reconheceria sabedoria independentemente da filosofia que os embasa". FAGOT-LAERGEAULT, 1989, p. 6/7 apud DURAND, 2003, p. 151.
} 
que, por outro lado, também não é absoluta, podendo ser restringida quando ameace a coletividade, por exemplo. O princípio de justiça, ademais, necessita de critérios que definam uma escolha justa, os quais são relativos e alteráveis no tempo ${ }^{59}$. Cada um dos princípios é, em certa medida, restringido em algumas ocasiões pela realização de outro, sendo impossível a concomitante aplicação total do conteúdo de todos eles.

Em outra perspectiva, Barreto entende que os princípios da bioética teriam sido definidos para proteger campos distintos da relação estabelecida entre médico, paciente e sociedade:

o princípio da beneficência enfatiza o papel do médico e, também, do pesquisador ao lidar com o corpo e a mente da pessoa humana; o princípio da autonomia refere-se ao espaço de autonomia decisória que cabe à pessoa humana em submeter-se a tratamento ou ser objeto de pesquisa; e, finalmente, o princípio da justiça tem a ver com a ação do poder público estatal e da sociedade, por onde se procura realizar o mais alto grau de justiça distributiva (BARRETO, 2001, p. 59).

$\mathrm{Ou}$ seja, os princípios em referência estabelecem uma relação de complementariedade entre si, podendo ser considerados válidos tão somente prima facie conforme terminologia introduzida por Ross ${ }^{60}$, e outrossim adotada por Alexy ${ }^{61}$. De fato, os avanços trazidos pela ciência e a necessidade de tomada de decisões cada vez mais complexas definiram a relativização de direitos que até então eram considerados absolutos. Passou-se a buscar a conciliação da máxima realização de cada um deles segundo critérios fundamentadores racionais. Contudo, é de se ressalvar a existência de diversas correntes que elegem um dos princípios da bioética para considerá-lo absoluto, ou que, então,

\footnotetext{
${ }^{58}$ BARBOZA, Heloisa Helena. Princípios do biodireito. In: Novos temas de bioética e biodireito. Heloisa Helena Barboza e Vicente de Paulo Barreto (org.). Rio de Janeiro: Renovar, 2003, p. 73.

${ }^{59}$ A idéia de justiça impõe a "exigência de que ninguém, de forma arbitrária e sem razão suficiente para isso, seja submetido a um tratamento que difere daquele que se dá a qualquer outra pessoa" (ROSS, Alf. Direito e justiça. Trad. Edson Bini. São Paulo: Edipro, 2000, p. 315). Tem, assim, um caráter histórico e relativo, pois não se dirige de forma absoluta a todos os indivíduos, dependendo do estabelecimento de critérios relevantes que determinem os membros de cada classe - a fim de que a igualdade se realize em seu aspecto distributivo. Os critérios de justiça podem ser, por exemplo: dar "a cada um segundo seu mérito, a cada um segundo sua contribuição, a cada um segundo suas necessidades, a cada um segundo sua capacidade, a cada um segundo sua posição e condição",59, etc., os quais são invocados em contextos fáticos diversos.

${ }^{60}$ ROSS, W. D. The right and the good. Oxford: Oxford University Press, 1930.
} 
afirmam a sacralidade da vida como princípio hegemônico e superior a todos os outros. Optamos, diversamente, por uma bioética secular, que seja capaz de avaliar os conflitos de valores existentes em sociedades contemporâneas: democráticas e plurais.

Até 1990 a concepção principialista proposta por Beauchamp e Childress havia sido pouco criticada. Entretanto, a publicação de um artigo entitulado " $A$ critic of principialism" por Clouser e Gert no "Journal of Medicine and Philosophy"62 suscitou novos debates no que tange à validade do principialismo, porquanto os referidos autores questionam a aparente arbitrariedade na seleção dos princípios e a inevitável vagueza dos mesmos; críticas que avaliaremos a seguir.

No que tange à afirmação de que os quatro princípios propostos no Informe Belmonte teriam sido enunciados arbitrariamente, entendemos que, contrariamente aos críticos, eles foram extraídos de uma análise da tradição ética médica ocidental, conforme já expusemos. Quanto à vagueza e relatividade dos princípios não há do que discordar. Partindo-se desta observação, podemos dizer que a abstração e generalidade inerente aos princípios permitem-lhes que sejam aplicados em casos concretos complexos e diversificados $^{63}$. Ademais, tais propriedades principiológicas garantem uma maior possibilidade de consensos morais diante da pluralidade cultural da atualidade.

Férrer e Álvarez (2003, p. 162) trazem, ainda, crítica relevante que reside na discussão sobre o eventual caráter utilitarista do paradigma principialista e da obra de Beauchamp e Childress. É certo, contudo, que o valor utilidade está claramente presente na proposta dos autores americanos em referência, que o abordam como sendo beneficência positiva, que "requer que os benefícios e as desvantagens sejam ponderados",64.

${ }^{61} C f$.ALEXY, Robert. Teoría de los derechos fundamentales. Centro de Estudios. Constitucionales, Madrid, 1993.

${ }^{62}$ CLOUSER, K. D. e GERT, B. “A critique of principialism”. Journal of Medicine and Philosophy 15, 1990, p. 219/236.

${ }^{63}$ Nesse sentido anota Comparato que "outra conseqüência importante do caráter essencialmente genérico dos princípios é que eles jamais podem ser aplicados, de forma rígida e absoluta, a todos os casos particulares. A compreensão de um princípio, na extrema riqueza de seus significados, exige, sobretudo, aquela sabedoria particular de que falavam os gregos. Os romanos bem compreenderam que o princípio de justiça pode ser totalmente negado em sua aplicação, quando se procura levá-lo abstratamente às últimas conseqüências, sem se atentar para o conjunto de circunstâncias que envolvem o caso concreto (summum ius, summa iniuria)". COMPARATO, 2006, p. 512.

${ }^{64}$ BEAUCHAMP e CHILDRESS, 2002, p. 281. 
Entendemos, assim, que, embora o princípio da utilidade não tenha sido explicitamente declarado no âmbito da bioética, traduz um valor considerado essencial pela civilização moderna ocidental - constituindo baliza ética para determinação de ações proporcionais. 


\title{
CAPÍTULO III - A ÉTICA E A PROTECC̃̃O DA DIGNIDADE HUMANA E DOS DIREITOS HUMANOS NA ERA DA GENÉTICA
}

\author{
"A filosofia não é uma doutrina, mas uma atividade". (Wittgenstein)
}

\section{A experiência moral.}

Para Sanchez Vazquez, com o qual concordamos, "a moral é um conjunto de normas aceitas livre e conscientemente, que regulam o comportamento individual e social dos homens" ${ }^{65}$. Ainda, nas palavras de Durand (2003, p. 69), "ela pode ser definida como um conjunto organizado, sistematizado, hierarquizado de principios, de regras ou de valores". Acrescentamos, contudo, entendermos que a moral seja histórica e que, portanto, a mesma norma moral possa apresentar conteúdo variável em contextos sociais diferentes. A sua função seria regular as relações mútuas dos indivíduos, visando, como bem anota o autor mexicano, "a preservar a sociedade no seu conjunto ou, no seio dela, a integridade de um grupo social" $"$.

De fato, a moral possui um componente social, porquanto ela se manifesta no seio das relações interpessoais em sociedade, cumprindo função verdadeiramente estruturante, regulando as relações entre os homens, para o fim de manter uma determinada ordem. Assim é que, com vistas a viabilizar a convivência em sociedade, à luz da vulnerabilidade do ser-humano, desenvolveram-se, ao longo da história humana, mecanismos de controle e adequação das condutas dos indivíduos: são os meios de controle social informal e formal.

E, embora não se possa afirmar que a moralidade seja o único elemento para a integração e submissão dos indivíduos a uma ordem dada, pois existem outras vias ainda mais concretas, como é o caso do direito, é de se ressaltar ser a moral é um dos meios mais eficazes, especialmente quando inserida em uma autocompreensão ética ${ }^{67}$.

\footnotetext{
${ }^{65}$ VAZQUEZ, Adolfo Sanchez. Ética. 16 ${ }^{\mathrm{a}}$ ed. Rio de Janeiro: Civilização brasileira, 1996, p.55.

${ }^{66}$ Idem, ibidem, p.55.

${ }^{67} C f$. HABERMAS, Jürgen. O futuro da natureza humana. São Paulo: Martins Fontes, 2004, p. 07.
} 
A existência deste tipo particular de regulamentação do comportamento humano significa não apenas que a sociedade não se contenta com uma aceitação exterior, formal ou forçada de certos princípios, normas ou valores - aceitação que é garantida pelo direito - mas que pretende, ao mesmo tempo, obter esta aceitação na esfera íntima ou privada da consciência individual, onde o direito e a força não podem influir de maneira decisiva (VAZQUEZ, 1996, p. 55).

Destarte, a moral cumpre uma função relevante para a manutenção da ordem social, sem que seja necessário recorrer à coerção, como ocorre com o sistema jurídico. $\mathrm{O}$ indivíduo se comporta moralmente dentro de um sistema de valores e normas morais que não inventou ou escolheu, mas que herdou da comunidade em que se encontra inserido.

É possível dizer que, de um ponto de vista antropológico, a moral funciona como dispositivo estruturante que compensa a vulnerabilidade das comunidades sociais. A particularidade dos seres-humanos residiria no ponto em que sua integração se dá em razão de um universo partilhado intersubjetivamente - em que a linguagem exerce papel preponderante. Os processos comunicativos são responsáveis pela consolidação da noção de identidade pessoal e comunitária, por meio do estabelecimento de uma relação entre o Eu e o Outro. Para Habermas (2004, p. 18) "com o sistema dos pronomes pessoais instalouse, então, um imperativo inflexível de individuação na linguagem de interação socializante orientada para a comunicação; através da mesma mediação da linguagem quotidiana, contempla-se, a um mesmo tempo, a intersubjetividade socializante".

\section{Valores, ética e conhecimento.}

Etimologicamente, a palavra valor provém do verbo valere do latim, ou seja, tudo aquilo que possui um valor, custo. Referindo-se a Rokeach, Cohen e Segre (2002, p. 19) definem valor como "uma crença duradoura em um modelo específico de conduta ou estado de existência, que é pessoalmente ou socialmente adotado, e que está embasado em uma conduta preexistente".

Deste sistema de valores são extraídas normas de conduta que estruturam a sociedade, definindo direitos e deveres dos indivíduos, e que constituem a sua moralidade, 
pois, como bem define o Prof. Miguel Reale, “é inegável o condicionamento do ser humano pelo sistema de valores dominantes em seu país, quadro esse configurado por certas escalas de prioridade e estilos de vida, prevalecentes tanto na existência cotidiana como nas expressões mais altas das atividades espirituais" $" 68$. Desse modo, partindo da premissa de que "os valores são realidades intencionalmente humanas" 69 , é de rigor considerarmos que o conteúdo axiológico de um valor seja historicamente determinado - do que decorre a conclusão de que não possuem um significado único e para sempre, embora sua forma abstrata transcenda a realidade histórica.

Os valores sempre estiveram no centro da noção de ética. A civilização greco-romana concebeu fontes escritas e não escritas para o direito. A lei não escrita, conhecida como ágraphos nómos e outrossim o ius gentium consubstanciavam-se em costumes, ou seja, "em normas aceitas como obrigatórias imemorialmente observadas na sociedade (aquilo que os jurisconsultos romanos denominavam consuetudo)" 70 , as quais fundavam-se, e legitimavam-se, na consciência ética coletiva, conceito, contudo, primeiramente apresentado por Émile Durkheim, o qual a definiu como "o conjunto das crenças e dos sentimentos comuns à média dos membros de uma mesma sociedade "71 aquilo que Comparato (2006, p. 18) chamou de "ideário ou mentalidade social"72.

Assim é que se pode considerar que os grandes valores sociais fundam-se na consciência ética coletiva e funcionam como guias de toda a estrutura de vida do homem em sociedade, articulando a vida sempre a partir de um horizonte estruturado - que seria o limite do que se pode ver. Ou seja, tudo ao seu redor é percebido segundo uma significação previamente elaborada. E estamos de modo tão profundo acostumados a considerar como

\footnotetext{
${ }^{68}$ REALE, Miguel. O homem e seus horizontes. São Paulo: Convívio, 1980, p. 49.

${ }^{69}$ COMPARATO, 2006, p. 506.

${ }^{70}$ Idem, ibidem, p. 514.

${ }^{71}$ DURKHEIM, Émile. De la división du travail social. Paris: Presses Universitaires de France, 10ª ed., 1978, p. 46.

${ }^{72}$ Nesse sentido, pode-se então afirmar que a proclamação das grandes declarações de direitos do século XVIII, bem como a da Declaração Universal de Direitos Humanos, representaram o resultado de um processo de formação da consciência ética coletiva ocidental, de cunho judaico-cristão, marcadamente influenciado pelas idéias da Reforma Protestante, das revoluções inglesas e do pensamento iluminista.
} 
natural as interpretações de mundo que herdamos: nosso horizonte cultural $^{73}$, que não nos damos conta de sua fugacidade e relatividade.

Dos valores decorrem os princípios e regras reguladores das condutas humanas - que podem ser considerados justamente a tradução normativa dos valores mais fundamentais à realização da vida do homem em sociedade. Nesse contexto, as regras cumpririam uma função social: "interpretar e concretizar os princípios, à luz do ideário vigente, em cada época histórica, nas diferentes culturas ou civilizações",74.

É de se ver, contudo, que, na antiguidade, ethos - ética - referia-se à dimensão pessoal do indivíduo, distinguindo-se dos usos e costumes, entendidos como a forma de comportamento ordenada de uma comunidade. Para Aristóteles a ética é considerada uma virtude, um modo de ser, identificado com a sabedoria e a prudência (virtudes da inteligência ou da razão). No mesmo sentido, embora muitos autores considerem a ética um conjunto de normas impostas pela sociedade - o que, para nós, diz com a moralidade -, concordamos com as idéias de Cláudio Cohen e Marco Segre (2002, p. 22), segundo os quais "a ética é apreendida, percebida, pelo indivíduo, ainda que não se possa dissociá-la do componente social".

É de se ver que "uma pessoa não nasce ética; sua estruturação ética vai ocorrendo juntamente com o seu desenvolvimento. De outra forma, a humanização traz a ética no seu bojo" ${ }^{, 75}$. Em uma visão psicanalítica, para Cohen e Segre (p. 21), a eticidade do indivíduo reside na sua “percepção dos conflitos da vida psíquica (emoção X razão)" e na sua capacidade de se posicionar “de forma coerente, face a esses conflitos". Com efeito, para referidos autores, a ética se fundamentaria em três pré-requisitos: "1. Percepção dos conflitos (consciência); 2. Autonomia (condição de posicionar-se entre a emoção e a razão, sendo que essa escolha de posição é ativa e autônoma); 3. Coerência" (2002, p. 21). Atendo-se ao âmbito da psicanálise, a ética estaria, então, intimamente relacionada com a

\footnotetext{
${ }^{73}$ Nas palavras do Prof. Reale (1980, p. 21), "o horizonte cultural corresponde, em suma, ao horizonte histórico alcançado em cada época, de tal modo que o 'mundo cultural'se acha em contínua transformação e desenvolvimento como resultado da força instituidora ou 'nomotética' do espírito".

${ }^{74}$ COMPARATO, 2006, p. 510.

${ }^{75}$ COHEN, Cláudio e SEGRE, Marco. Definição de valores, moral, eticidade e ética. In: Bioética. SEGRE, Marco e COHEN, Cláudio, São Paulo: Edusp, 2002, p. 17
} 
estruturação do ego, por meio da tolerância à frustração, processo o qual Melanie Klein ${ }^{76}$, referida por Cohen e Segre, teria descrito como sendo a busca de cada pessoa pelo seu crescimento e integração aos valores de uma comunidade ${ }^{77}$. Desse modo, um indivíduo poderia ser considerado ético quando alcançasse maturidade emocional suficiente para desenvolver uma personalidade bem integrada, "que lhe permita lidar com as emoções conflitantes, uma força de caráter, um equilíbrio de vida interior e um bom grau de adaptação à realidade do mundo"78

Referida noção de ética remete-nos à esfera mais íntima do indivíduo, onde se fundem razão e emoção, componentes que possuem uma dimensão pessoal diretamente influenciada por uma dimensão social axiologicamente concebida, também definida como cultura. Para Reale, parece "inegável que nenhum homem, desde o homem comum ao mais realizado dos artistas ou dos cientistas, pode libertar-se do 'sistema de cultura' a que pertence, e que constitui componente inarredável de seu ser espiritual"79.

E, ainda, complementa o Professor Reale (1980, p.49/50):

\begin{abstract}
Invoque-se esta ou aquela outra razão fundante da apontada realidade humana, empreguem-se ou não expressões polêmicas como 'espírito do povo', 'voz do sangue', 'força da terra' etc., o certo é que há sempre um 'envolvente históricosocial' ao qual, queiramos ou não, nos toca pertencer, e do qual jamais nos desvencilhamos, mesmo quando, por um ato de vontade, decidimos fixar alhures a nossa morada. Trata-se, pois, de uma 'dimensão cultural' distinta da 'dimensão pessoal', ambas pensáveis em unidade dialética de complementaridade, em função de relações de conformidade ou de conflitos condicionados pela polaridade indivíduo-comunidade.
\end{abstract}

\footnotetext{
76 "A maturidade emocional, segundo Klein (1976), seria a capacidade do indivíduo de poder transformar, através de alguma elaboração, os desejos e as fantasias infantis em fontes de interesse e de enriquecimento da personalidade. A maturidade emocional também está vinculada à capacidade de suportar as frustrações, pois somente quando aprendemos a suportar a dor emocional é que podemos nos desenvolver. Um exemplo do exercício dessa função é o de aprendermos a tolerar a frustração de não sermos onipotentes, isto é, passarmos a aceitar as nossas limitações". (COHEN e SEGRE, 2002, p. 23).

77 "Sob o enfoque psicanalítico, seria o Ego ou o Self que poderia cumprir essa função, pois é essa instância psíquica que pode lidar com as pulsões vindas do Id e as ordens do Superego. Para Laplanche e Pontalis (1968) o Ego, sob o ponto de vista tópico, encontra-se em relação de dependência tanto quanto às reivindicações do Id, como quanto aos imperativos do Superego e às exigências da realidade, sendo que no indivíduo maduro ele deve funcionar como mediador e unificador dessas forças de interesses diferentes". (COHEN e SEGRE, 2002, p.22/23).

${ }^{78}$ COHEN e SEGRE, 2002, p. 22
} 
Destarte, adotaremos nesse trabalho, a posição sustentada por Cohen e Segre de que a eticidade do indivíduo reside na sua "percepção dos conflitos da vida psíquica (emoção X razão)" e na sua capacidade de se posicionar "de forma coerente, face a esses conflitos". No mesmo sentido, com base em sua teoria da argumentação, expõe Habermas que para que a moral seja cogente para o indivíduo, deve encontrar-se aceita por uma escolha ética da consciência do próprio indivíduo, pois "sem a pressuposição subjetiva da capacidade de consenso numa comunidade ideal de comunicação, também a decisão de consciência do indivíduo, no sentido da ética da comunicação, não pode ser moralmente cogente para ele mesmo" $" 80$.

Contudo, não é de se olvidar a influência da teoria ética kantiana no campo da bioética, porquanto, a noção de ética como dever, preconizada por Immanuel Kant, tem sido utilizada como fundamento para a eticidade individual. Demais disso, a noção de dignidade desenvolvida pelo filósofo retoma as idéias do período Axial da história humana, sobre o qual já discorremos, e acompanha o pensamento ocidental até os dias atuais - o que denota sua importância.

Inaugurando a filosofia crítica, Kant afirmou depender o conhecimento de duas variáveis subjetivas: o tempo e o espaço - que influenciam de modo relevante as impressões sensíveis humanas. Ou seja, a realidade nunca poderia ser captada como ela é verdadeiramente, mas, ao contrário, seria experimentada por um sujeito inserido em um horizonte previamente determinado. As premissas desse pensamento não divergem, por completo, embora não as possamos considerar inteiramente convergentes, das idéias expostas por Miguel Reale, para quem “o que se percebe é a realidade vista pelo sujeito, pois ela é somente tal como é percebida ou captada segundo "condições subjetivas",81. O homem é sempre um ser condicionado a partir da sociedade em que passa a integrar. Não existe, portanto, pensamento in abstracto, sendo o ato de pensar sempre circunstanciado. Propõe Reale (2000, p. 40/41) a noção de conhecimento como ato cultural, para o qual "no instante mesmo em que se pensa algo, algo se objetiviza como um elemento transubjetivo,

\footnotetext{
${ }^{79}$ REALE, 1980, p. 49.

${ }^{80}$ APEL, Karl-Otto. Os conflitos de nossa época e a exigência de uma orientação ético-política fundamental. Estudos de moral moderna. Petrópolis: Vozes, 1994, p. 213.

${ }^{81}$ REALE, Miguel. Cinco temas do culturalismo. São Paulo: Saraiva, 2000, p. 37.
} 
que, por mais elementar que seja, compõe o mundo da cultura". Kant, a seu turno, em sua obra Crítica da Razão Pura, propõe que somente é dado ao homem conhecer fenômenos, isto é, o que é passível de ser apreendido pelos sentidos e processado pelo intelecto.

Assim, para o filósofo alemão, as pessoas experimentam o mundo natural de forma diferenciada. Cada um interpreta a realidade através de uma perspectiva própria, pois o elemento tempo-espacial, que é cambiante, determina o pensamento humano. Contudo, e nesse ponto, especificamente, Kant mostra-se um racionalista, pois considera que não obstante o elemento empírico difira de pessoa para pessoa, o processo da razão é o mesmo. Ou seja, por serem os homens dotados de categorias universais que lhes permitem perceber a realidade, é dado a eles conhecer leis universais, embora o elemento natural seja contingente - o que não obsta a noção de que existam limites para o conhecimento do ser humano, por conta das limitações tempo-espaciais a que se submete o ser racional.

De fato, inserido em um contexto de contradições e disputas religiosas, Kant buscou uma fundamentação para a ética que fosse capaz de transpor as questões ligadas à religião. Assim é que, incluído no movimento iluminista, destacou-se como um racionalista não puro, porquanto, em certa medida, propôs a ligação entre a razão e o sentimento embora tenha sublinhado a proeminência da razão. O filósofo baseou-se na orientação cartesiana, que tanto influenciou o pensamento moderno, para tentar encontrar um conhecimento com bases racionais, pois, muito embora considerasse que a apreensão do conhecimento se iniciasse pela experiência, através dos sentidos, acreditava ser possível alcançar um conhecimento que ultrapassasse a dimensão estritamente empírica: "fundado em faculdades racionais, independentes de toda experiência sensorial; um conhecimento que Kant denominou a priori ou puro, enquanto o derivado dos sentidos é necessariamente a posteriori ou impuro" ${ }^{\prime 2}$.

Nesse sentido, já no prefácio escrito à sua obra Fundamentos para uma Metafísica dos Costumes”, Kant (2003, p. 57) anuncia que o objetivo de suas reflexões éticas consistia em encontrar princípios que se originem "de bases a priori para que tenham

${ }^{82}$ COMPARATO, 2006, p. 287/288. 
validade universal no sentido estrito". Assim, utilizando o que chamou de método crítico, na tentativa de livrar-se do relativismo da experiência empírica, "partiu do postulado de que não podemos descobrir a verdade nas coisas, porque elas estão fora de nós" ${ }^{\prime 3}$, mas que seria possível descobrirmos "princípios racionais, não deduzidos pelo raciocínio, mas que ao contrário, o condicionam, em todos os campos" ${ }^{\prime 4}$.

Trata-se, como se percebe, de um método de pensamento idealista ou racionalista: a verdade não se encontra fora da razão humana, mas dentro dela. Os escolásticos diziam que o conhecimento da verdade supõe a adequação do pensamento à coisa pensada (adequatio intellectus ad rem). A filosofia moderna, a partir de Descartes, inverte a explicação: tudo que podemos saber com certeza está em nossa mente e não fora dela. A filosofia deixa, portanto, de ser meramente especulativa (speculum $=$ espelho), refletindo a realidade exterior, e passa a ser introspectiva: a tarefa do filósofo consiste em descobrir as leis que regem o nosso pensamento, não só o pensamento em si mesmo (a lógica), mas o pensamento como instrumento de captação da realidade exterior (o que Kant denominou metafísica). Em outras palavras, o saber filosófico é, antes de tudo, uma epistemologia, uma análise do conhecimento. (COMPARATO, 2006, p. 288).

Com efeito, Kant distingue a razão pura da razão prática, considerando, contudo, que ambas provêm de princípios transcendentais, independentes de qualquer experiência sensível.

Reinterpretando a ética da virtude proposta por Aristóteles e, de certa forma, distanciando-se dela, Kant funda uma ética do dever, com base em princípios objetivos do agir humano. Para ele, “o princípio do dever é deduzido da razão pura, não podemos evitar imaginar como esse princípio poderia ser reduzido novamente a uma doutrina da felicidade" ${ }^{\prime 85}$. Ou seja, a virtude é vista como a "conformidade da vontade a todo dever" ${ }^{, 86}$, como a "força moral da vontade de um ser humano no cumprir seu dever, um constrangimento moral através da sua própria razão legisladora" ${ }^{\natural 7}$. Desse modo, afirma que

\footnotetext{
${ }^{83}$ Idem, ibidem, p. 288.

${ }^{84}$ Idem, ibidem, p. 288.

${ }^{85}$ KANT, 2003, p. 221.

${ }^{86}$ Idem, ibidem, p. 239.

${ }^{87}$ Idem, ibidem, p. 248.
} 
“a virtude está sempre em progresso e, apesar disso, sempre parte do início. Está sempre em progresso porque, objetivamente considerada, é um ideal inatingível, enquanto, não obstante isso, a aproximação constante dela é um dever" ${ }^{\prime 8}$.

O princípio da ação recebe, portanto, a forma de um comando de razão, chamado de imperativo, expresso pelo verbo dever (sollen), e seu cumprimento é moralmente bom quando determinado por uma representação racional, e não simplesmente quando é agradável aos sentidos, como bem anota Cattaneo: "o dever não se funda no sentimento ou nas inclinações, mas simplesmente na relação recíproca dos seres racionais, na qual a vontade de cada um deve ser sempre considerada como legisladora, porque do contrário os seres racionais não poderiam pensar como fins em si”, 89 .

O imperativo é denominado hipotético quando apenas indica os meios para a realização de um fim; é, contudo, categórico quando define um postulado definitivo e universal, afirmando um valor último e válido por si mesmo - que seria, portanto, indiferente às contingências circunstanciais. Nas palavras de Cassirer "como esse valor fundamental não pode buscar-se já em nenhum conteúdo específico da vontade, senão somente nas leis gerais desta, ficam perfeitamente definidos por este último fato o conteúdo e o objeto do único imperativo categórico possível" ${ }^{90}$, o que Kant (2003, p. 239) outrossim denomina como sendo o princípio supremo da doutrina da virtude: "age de acordo com uma máxima dos fins que possa ser uma lei universal a ser considerada por todos”. Emerge, com efeito, no pensamento kantiano a idéia de unidade do gênero humano, porquanto supôs Kant que deveria haver uma lei que os indivíduos desejassem que fosse universal - verdadeiro imperativo categórico. Nas palavras de Salgado:

A primeira fórmula do imperativo categórico expressa a exigência de universalidade da lei moral e, mais precisamente, da máxima, como critério de sua própria validade. A máxima que pode ser elevada à categoria de lei, isto é, universalizada, é válida moralmente. E é válida não só para quem elaborou a

\footnotetext{
${ }^{88}$ Idem, ibidem, p. 252.

${ }^{89}$ Tradução livre de: "il dovere non se funda sul sentimento o sulle inclinazioni, ma meramente sul rapporto recíproco degli esseri razionali, nel quale la volontà di ciascuno devere essere sempre considerata come legislatrice, perchè altrimenti gli essere razionali non potrebbero pensare come fini in sé”. CATTANEO, Mario. La dignità umana e pena nella filosofia di Kant. Milano: Giuffrè, 1981, p. 09.

${ }^{90}$ CASSIRER, Ernest. Kant, vida y doctrina. México: Fondo de Cultura Econômica, 1993, p. 289.
} 
máxima, mas para todos os seres racionais, vale dizer, para todos os seres a eles iguais, tendo-se como padrão de igualdade a racionalidade dos seres em questão ${ }^{91}$.

Seu ponto de partida para a enunciação do primeiro imperativo categórico, princípio maior para o agir ético, em consonância com uma virtude revisitada segundo a razão, é o importante mandamento do amor ao próximo ${ }^{92}$. Em sua obra A Crítica da Razão Prática, afirma o filósofo alemão que "o amor ao próximo, 'essa lei de todas as leis', apresenta, como todo preceito moral do Evangelho, a intenção moral em toda a sua perfeição; ela é, da mesma sorte, um ideal de santidade, do qual devemos nos esforçar para no aproximarmos, num progresso ininterrupto, mas infinito" ${ }^{93}$.

Referido mandamento maior submete, contudo, o sujeito ao dever de bemquerer $^{94}$, e não ao de amar, no sentido estrito desse sentimento. De fato, na segunda parte da Doutrina da Virtude, contida em sua obra A Metafísica dos Costumes, Kant (2003, p. 244) distingue a noção de amor daquela de bem-querer, sublinhando que somente o bem-querer fundar-se-ia na vontade: "o amor é uma matéria do sentir, não do querer e não posso amar porque o quero e, ainda menos, porque o devo (não posso ser constrangido a amar); por conseguinte, um dever de amar é um absurdo. Mas a benevolência (amor benevolentiae), como conduta, pode estar sujeita a uma lei do dever". Assim, define o filósofo, "fazer o bem a outros seres humanos na medida de nossa capacidade é um dever, quer os amemos ou não"95.

O dever de “amor ao próximo” (bem-querer), segundo Kant (2003, p. 293), também poderia "ser expresso como o dever de fazer dos fins dos outros o meu próprio (desde, unicamente, que estes não sejam imorais)" - noção intrinsecamente ligada ao imperativo categórico supracitado. Assim é que, o dever de respeito pelo próximo é

\footnotetext{
${ }^{91}$ SALGADO, Joaquim Carlos. A idéia de justiça em Kant: seu fundamento na liberdade e na igualdade. $2^{\text {a }}$ ed. Belo Horizonte: Editora UFMG, 1995, p.219.

${ }^{92}$ Registre-se que o mandamento do amor ao próximo, preponderante na tradição ética judaico-cristã, também foi enunciado por outras civilizações, como bem se vê da análise do período que Jaspers chamou de Axial da história humana.

${ }^{93}$ KANT, Immanuel. A Crítica da Razão Prática. São Paulo: Scala, 2004, p. 105/106.

94 "Ser beneficente, ou seja, promover com os próprios meios a felicidade de outros seres humanos necessitados, sem esperar por algo em retorno, é o dever de todos, já que todo aquele que se acha em necessidade deseja ser ajudado por outros". (KANT, 2003, p. 296).
} 
fundamento e conseqüência da "máxima de não degradar qualquer outro ser humano, reduzindo-o a um mero meio para os meus fins" $"$. Destarte, "a ética também pode ser definida como o sistema dos fins da pura razão prática" ${ }^{\text {97. }}$.

De fato, ele procurou travar uma separação absoluta entre as coisas e os seres humanos, considerando que, enquanto uma coisa tem valor econômico (preço) ou afetivo (relativo), os seres humanos não têm preço e seu valor independe da afeição, pois têm a substância de pessoa, e a pessoa é um fím em si mesmo; ela nunca pode ser considerada um meio, ainda que nobre. Do valor inerente ao ser-humano, como um fim em si, deduz-se a máxima: "Aja de tal modo que você trate a humanidade tanto em sua pessoa como na pessoa de todos os outros sempre ao mesmo tempo como fim, e jamais como simples meio".

Partindo da noção de autocompreensão de si mesmo, explica Cassirer (1993, p. 291), analisando a teoria kantiana, que, em contraposição à noção de coisa, surge, então, aquela de pessoa "como unidade consciente e certa de si mesma. É nela que, pela primeira vez se realiza a idéia do fim em si mesmo e do fim último" ${ }^{98}$. E completa:

\footnotetext{
Os seres cuja existência não responde à nossa vontade, senão à natureza, somente têm, se são seres irracionais, um valor puramente relativo, como meios, e se chamam, portanto, coisas; enquanto os seres racionais recebem o nome de pessoas porque sua natureza caracteriza-os como fins em si mesmos, é dizer, como algo que não pode ser empregado simplesmente como meio e que, portanto, põe termo a todo capricho. (CASSIRER, 1993, p. 292).
}

Enunciamos, então, a noção de dignidade humana segundo a ética do dever kantiana, segundo a qual "todo ser humano tem um direito legítimo ao respeito de seus semelhantes e está, por sua vez, obrigado a respeitar todos os demais" 99 , ao fundamento de que a humanidade possui uma dignidade intrínseca, "pois um ser humano não pode ser

\footnotetext{
${ }^{95}$ KANT, 2003, p. 244.

${ }^{96}$ Idem, ibidem, p. 293.

${ }^{97}$ Idem, ibidem, p. 225.

${ }^{98}$ Nas palavras de Kant (2003, p. 239): "De acordo com este princípio, um ser humano é um fim para si mesmo, bem como para outros, e não é suficiente não estar ele autorizado a usar a si mesmo ou a outros meramente como meios (uma vez que ele poderia, neste caso, ainda ser indiferente a eles); é em si mesmo seu dever fazer do ser humano como tal seu fim".
} 
usado meramente como um meio por qualquer ser humano (quer por outros quer, inclusive, por si mesmo), mas deve sempre ser usado ao mesmo) tempo como um fim"100.

É precisamente nisso que sua dignidade (personalidade) consiste, pelo que ele se eleva acima de todos os outros seres do mundo que não são seres humanos e, no entanto, podem ser usados e, assim, sobre todas as coisas. Mas exatamente porque ele não pode ceder a si mesmo por preço algum (o que entraria em conflito com seu dever de auto-estima), tampouco pode agir em oposição à igualmente necessária auto-estima dos outros, como seres-humanos, isto é, ele se encontra na obrigação de reconhecer, de um modo prático, a dignidade da humanidade em todo outro ser humano. Por conseguinte, cabe-lhe um dever relativo ao respeito que deve ser demonstrado a todo outro ser humano". (KANT, 2003, p. 306).

Com efeito, em razão de o ser-humano ser o único a comportar-se segundo as leis que edita com fundamento na autonomia da vontade, não pode ser utilizado como meio para qualquer fim, porquanto cada pessoa é um fim em si mesma, do que decorre a sua dignidade ${ }^{101}$ : designada pelo sentimento do respeito, sobre o qual discorre o filósofo alemão na Crítica da Razão Prática. Assim é que se pode arrematar a teoria kantiana com a sua noção de liberdade ${ }^{102}$ - chave para a compreensão de suas idéias, porquanto, para referido autor, a liberdade constitui fundamento para a dignidade humana e para o direito baseada na "capacidade da razão pura de ser, por si mesma, prática"103 - o que somente seria possível, caso toda ação pudesse estar sujeita a uma lei universal ${ }^{104}$.

\footnotetext{
${ }^{99}$ KANT, 2003, p. 306.

${ }^{100}$ Idem, ibidem, p. 306.

${ }^{101}$ Nesse sentido, sublinhamos as palavras de Cattaneo (1981, p. 07/08): "Questo principio dell'umanità e di ogni natura razionale come fine in si stessa, chi è la condizione suprema limitatrice della libertà delle azioni di ogni uomo, non è derivato dall'esperienza: in primo luogo, per la sua generalità, in quanto riguarda tutti gli esseri razionali, in relazione ai quali l'esperienza non è in grado di decidere nulla; in secondo luogo, perchè l'umanità è in esso vista come fine oggettivo e non soggetivo: quali siano gli scopi particolari che ci proponiamo, l'umanità (come legge) deve essere la suprema condizione limitatrice di tutti i fini soggetivi, e perciò deve derivare dalla prima ragione. La base di ogni legislazione pratica sta oggettivamente nla regola e nella forma dell'universalità, che la mette in grado di essere uma legge, ma soggettivamente è posta nel fine, ora il soggeto di tutti i fini è ogni essere razionale, come fine in se stesso".

102 "O conceito de liberdade é um conceito racional puro e que por isto mesmo é transcendente para a filosofia teórica, ou seja, é um conceito tal que nenhum exemplo que corresponda a ele pode ser dado em qualquer experiência possível”. (KANT, 2003, p. 64).

${ }_{103}^{103}$ Idem, ibidem, p. 63.

${ }^{104}$ No que concerne à noção de liberdade como fundamento para uma lei universal, comenta Comparato: "Não se poderia dizer melhor para expressar o fundamento universal de validade dos direitos humanos. Tudo
} 
Consoante referido conceito de autonomia, a vontade não se submete a outra norma senão àquela tida como norma geral, fundada na razão. Para Cattaneo (1981, p. 05), a vontade consiste em faculdade inerente aos seres racionais de se determinarem e agirem em conformidade com regras da razão. Assim, considerando os universalistas kantianos a racionalidade como categoria universal, comum a todos os seres-humanos, propugnam que ela seria o instrumento mais adequado para a determinação de valores livremente aceitos por todos os homens - que proporcionariam uma concepção ética universal.

No âmbito do direito, o caráter universalista do pensamento kantiano é destacado em sua obra Para a paz perpétua - Um projeto filosófico, a qual foi, primeiramente, publicada em 1795, mesmo ano em que a República francesa e a Prússia celebraram um tratado de paz. Preconizou o filósofo verdadeiro anteprojeto de tratado internacional, no qual, brilhantemente, e de forma original, sustentou que os Estados seriam sujeitos de direitos na esfera internacional, em oposição às noções anteriores de que os monarcas e príncipes o seriam - acrescentando, ainda, ao lado dos Estados, a posição de cada indivíduo como sujeito de uma "cidadania mundial" decorrente de um direito cosmopolita. Ressaltamos, nesse sentido, anotação feita por Habermas de que:

A chave do direito cosmopolita reside no fato de que ele concerne, ademais dos sujeitos coletivos do direito internacional, o estatuto dos sujeitos de direitos individuais, fundando a eles um pertencimento direto à associação dos cosmopolitas livres e iguais. Carl Schimitt sublinhou muito bem este ponto compreendendo que, seguinto tal concepção, 'todo indivíduo é [...] portanto cidadão do mundo (ao pleno senso do termo) e cidadão de seu Estado ${ }^{105}$.

De fato, até Kant eram concebidas duas dimensões para o direito: o de natureza estatal, desenvolvido no âmbito interno de cada Estado, e o direito das gentes, decorrente das relações travadas entre Estados e entre indivíduos de um Estado com os de

se reduz, afinal, a um princípio original que só pode ser encontrado nos seres racionais: a liberdade. Ela representa, como diz Kant, a chave explicativa da autonomia da vontade". (COMPARATO, 2006, p. 297).

${ }^{105}$ Tradução livre de: "la clef du droit cosmopolitique réside dans le fait qu'il concerne, par-delà les sujets colletifs du droit international, le status des sujets de droit individuels, fondant pour ceux-ci une appartenance directe à l'association des cosmopolites libres et egaux. Carl Schimitt a bien saisi ce point en comprenant que, suivant cette conception, 'tout individu est [...] à la fois citoyen du monde (au plein sens du terme) et citoyen de son État”. HABERMAS, Jürgen. La paix perpétuelle. Le bicentenaire d'une idée kantienne. Trad. Rainer Rochlitz, Paris: Les Éditions du CERF, 1996, p. 58. 
outro. Contudo, em sua obra, A paz perpétua, ao discorrer sobre o que chamou de direito cosmopolita, Kant acresce-lhe uma terceira dimensão: o direito dos cidadãos do mundo, de verdadeira sociedade cosmopolita.

O cosmopolitismo kantiano é apresentado no terceiro artigo da Paz perpétua como a terceira condição positiva para a paz e parte da idéia de que sendo a Terra uma superfície finita, "fechada sobre si mesma", é impossível evitar-se certa proximidade entre os povos, que se influenciam reciprocamente. Ao formulá-lo, Kant pondera que se deve "limitar às condições de uma hospitalidade universal"", a qual se fundaria na noção de que todos têm o mesmo direito ao solo do planeta e que, destarte, "ninguém tem mais direito que um outro de estar em um lugar da Terra". Nesse sentido, ao analisar a obra de Kant, Nour anota que:

Do direito à liberdade decorre o direito sobre o próprio corpo e, como o corpo precisa de espaço, a propriedade originária coletiva sobre o solo. Disso se origina o "direito de visita", ou seja, o direito do cidadão da Terra de tentar a comunidade com todos e, para esse fim, de visitar todos os lugares da Terra, bem como o "direito à hospitalidade", ou seja, o direito de, nessa tentativa de se relacionar com o outro, não ser tratado pelo estrangeiro como inimigo ${ }^{107}$.

O filósofo de Könisberg foi, em verdade, inovador, ao desenvolver uma nova dimensão do direito, até então limitado ao direito estatal e ao direito das gentes. Tratase do referido direito cosmopolita, que insere o indivíduo em uma sociedade de dimensões mundiais. De fato, ele foi um dos primeiros a afirmar o caráter jurídico de um direito comum dos povos: "trata-se aqui, como nos artigos precedentes, não de filantropia, mas de direito", como bem sublinha Kant (1997, p. 137). Destarte, doravante, a proteção dos direitos humanos passou a encontrar lugar na doutrina do direito, através da preconização de um estado cosmopolita, com base institucional, fundado na idéia de que "os povos da terra participam em graus diferentes de uma comunidade universal, que se desenvolveu a ponto de que a violação de um direito numa parte do mundo, repercute em todos os

\footnotetext{
${ }^{106}$ KANT, Immanuel. A paz perpétua e outros opúsculos. Trad. Artur Morão. Lisboa: Edições 70, 1997, p. 137.

${ }^{107}$ NOUR, Soraya. À paz perpétua de Kant. São Paulo: Martins Fontes, 2004, p. 56.
} 
lugares" ${ }^{108}$. E, desse modo, o direito torna-se relevante instrumento de coordenação da relação estabelecida entre os povos.

Com efeito, as condições preliminares para a paz entre os povos são descritas "pela idéia de coexistência pacífica e de colaboração pacífica entre os diferentes povos da Terra, excluindo qualquer idéia de paz armada, de animosidade, de propaganda belicosa e de competição em vista da supremacia internacional”. (NOUR, 2004, p. 29). O conceito de pessoa definido em sua teoria filosófica - sobre o qual já discorremos constitui o princípio fundamental da noção de cosmopolitismo, porquanto determina que qualquer pessoa não pode ser usada como meio para fins bélicos. Kant propõe uma interpretação analógica entre o estado de natureza dos indivíduos e um estado natural entre os Estados: "povos, como Estados, podem ser julgados como particulares que, em seu estado de natureza (isto é, em sua independência quanto a leis exteriores), lesam-se já por sua coexistência em uma constituição semelhante à constituição cívica, que assegure a cada um o seu direito". Com fundamento na razão, os Estados deverão, então, para Kant, constituir um Estado de povos - ou, como dizia em 1793, em Teoria e Práxis, um Estado universal.

Contudo, a paz de um alegado Estado mundial deveria decorrer da liberdade e não do despotismo, pois Estados soberanos não admitem subordinação ou diminuição de sua soberania. Ele propõe, então, um direito recíproco dos povos, verdadeira aliança de povos, mas não um Estado de povos, porquanto não seria cabível uma relação de subordinação entre superior e inferior. Assim, o autor alemão afasta a idéia de formação de um Estado com soberania universal, vez que impossível. Todavia, embora Kant afaste a idéia de um Estado universal, exige que o direito cosmopolita tenha algum fundamento institucional. Destarte, ele propõe uma aliança entre os povos, de natureza federativa ${ }^{109}$. Em suas palavras:

\footnotetext{
${ }^{108}$ KANT, 1997, p. 140

${ }^{109}$ Interessante anotar observação de Nour (2004, p. 54), de que "para Kant, um Estado mundial é não apenas impossível do ponto de vista político como inaceitável do ponto de vista moral: a diversidade das culturas, que é moralmente desejável, deve ser preservada. Em seus estudos de ciências naturais pré-críticos, Kant considera o mundo material não atomicamente, mas dinamicamente, como campo de forças de atração e repulsão. $\mathrm{O}$ mundo espiritual segue o modelo do mundo material: um sistema de forças em conflito. A
} 
Os povos podem, enquanto Estados, considerar-se como homens singulares que no seu estado de natureza (isto é, na independência de leis externas) se prejudicam uns aos outros já pela sua simples coexistência e cada um, em vista da sua segurança, pode e deve exigir do outro que entre com ele numa constituição semelhante à constituição civil, na qual se possa garantir a cada um o seu direito. Isso seria uma federação de povos que, no entanto, não deveria ser um Estado de povos. Haveria aí uma contradição, porque todo o Estado implica a relação de um superior (legislador) com um inferior (o que obedece, a sabe, o povo) e muitos povos num Estado viriam a constituir um só povo, o que contradiz o pressuposto $^{110}$.

Nesse ponto, indaga Comparato (2006, p. 301) se "Kant não se deixou impressionar pela Constituição norte-americana de 1787, que transformou a clássica confederação (já existente na Suíça havia vários séculos) em uma união mais estreita de unidades estatais autônomas". Certo é que Kant (1997, p. 135), verdadeiramente, considera que a idéia de cosmopolitismo deveria realizar-se por meio de uma federação, que deveria “estender-se paulatinamente a todos os Estados", conduzindo "à paz perpétua".

A paz perpétua somente seria possível em uma comunidade global que assegurasse a liberdade de todos por meio de leis que fossem um produto da vontade coletiva. Assim é que a paz perpétua pode ser concebida como o coroamento da filosofia kantiana universalista. E, desde já, sublinhamos que a noção de cosmopolitismo preconizada por Kant resta por ser reavivada no século XX como orientação universalista para a doutrina dos direitos humanos. Nesse sentido, para Habermas (1996, p. 64), “nós podemos compreender a situação atual do mundo como uma transição entre o direito internacional e o direito cosmopolita" ${ }^{\prime 11}$, que, certamente, ao autor alemão, seria possibilitado por meio do agir comunicativo, fundado em uma ética discursiva universalista e dialógica, conforme se verá.

sociedade, a ciência e a cultura, de modo análogo ao mundo material, desenvolvem-se a partir de antagonismos".

${ }^{110}$ KANT, 1997, p. 132.

111 Tradução livre de: "on peut comprendre la situation actuelle du monde comme une transition entre le droit international et le droit cosmopolitique”. (HABERMAS, 1996, p. 64). 


\section{A dicotomia universalismo versus relativismo cultural.}

Para alguns, os direitos humanos supõem uma constante histórica cujas raízes remontam às instituições e ao pensamento do mundo clássico. Outros, ao contrário, sustentam que a Idoia dos direitos humanos nasce com a afirmação cristã da dignidade moral do homem enguanto pessoa. Face a esses últimos, por sua vez, há quem afirme que o cristianismo não supôs uma mensagem de liberdade, mas uma aceitação conformista do fato da escravidão humana. Inobstante, o mais frequente é considerar que 'a primeira aparição da idoia de direitos do homem $[\ldots]$ teve lugar durante a luta dos povos contra o regime feudal e a formação das relações burguesas.

Às vezes se considera que os direitos humanos são fruto da afirmação dos ideais naturalistas, enquanto outras vezes se considera que os termos 'direitos naturais' e 'direitos humanos' são categorias que não se implicam necesariamente, ou, inclusive, entre as que antes de uma continuidade existe uma alternativa.

De outra parte, é muito comum sustentar que os direitos humanos são produta da progressiva afirmação da individualidade. Assim sendo, enquanto há quem estime que tal afirmação só se produz diante da dissolução da ordem iusnaturalista, enquanto ordem universal, aistórica e heterônima, incompatible com a autonomia e o subjetivismo ético do mundo moderno em que se edificam os direitos humanos, sustenta-se, de uma outra perspectiva, com idêntica pathos a tese contrária, isto é, que foi o jusnaturalismo, enquanto ética da razão, o fundamento inspirador do clima liberal e democrático em que surgiram os direitos do homem ${ }^{112}$.

\footnotetext{
${ }^{112}$ Tradução livre de: "Para algunos, los derechos humanos suponen una constante histórica cuyas raices se remontan a las instituiciones y el pensamiento del mundo clássico. Otros, por el contrario, sostienen que la idea de los derechos humanos nace con la afirmación cristiana de la dignidad moral del hombre en cuanto persona. Frente a estos últimos, a su vez, hay quien afirma que el cristianismo no suposo um mesaje de libertad, sino más bien una aceptación conformista del hecho de la esclavitud humana. Sin embargo, lo más frecuente es considerar que ' la primera aparición de la idea de derechos del hombre (...) tuvo lugar durante la lucha de los pueblos contra el regimén feudal y la formación de las relaciones burguesas.

Unas veces se considera que los derechos humanos son el fruto de la afirmación de los ideales iusnaturalistas; en tanto que en otras se considera que los términos 'derechos naturales' y 'derechos humanos' son categorias que no se implican necesariamente, o, incluso entre as que antes de una continuidad existe una alternativa.

De otra parte, es muy corriente sostener que los derechos humanos son producto de la progresiva afirmación de la individualidad. Ahora bien, mientras hay quien estima que tal afirmación sólo se produce tras la disolución del orden iusnaturalista, en cuanto orden universal, ahistórico y heterónomo, incompatible con la autonomia y el subjetivismo ético del mundo moderno en el que se edifican los derechos humanos, se sostiene
} 
Durante muitos séculos, acreditou-se que a elaboração de razões e argumentos irresistíveis possibilitaria encontrar o fundamento absoluto dos direitos mais importantes para o ser humano, direitos verdadeiramente fundamentais, aos quais ninguém poderia recusar sua adesão. Os jusnaturalistas supunham ter colocado alguns direitos acima de qualquer possibilidade de refutação, derivando-os, para tanto, da natureza humana. Hannah Arendt, por outro lado, afirma que os direitos humanos não são um dado, mas um construído, uma invenção humana, em constante processo de construção e reconstrução ${ }^{113}$.

Este processo de reconstrução dos direitos humanos insere-se no contexto da globalização, que delineia novas fronteiras para a proteção dos valores considerados fundamentais para o pleno desenvolvimento da pessoa humana. Assim, a proteção dos direitos humanos passa a constituir tema de relevância para toda a humanidade, transpondo, portanto, os domínios do Estado moderno para inserir-se no âmbito de atuação do direito internacional - constatação que nos remete, portanto, à dicotomia existente entre universalismo e relativismo cultural, que será abordada a seguir.

\subsection{Universalismo.}

Apesar dos antecedentes greco-romanos e medievais, a noção de direitos universais nasce com a filosofia da ilustração e a ascensão do mundo moderno, que, com base na racionalidade, propôs a proclamação de direitos abstratos, atemporais e válidos para todos os homens. Os universalistas kantianos consideram a racionalidade como categoria universal, comum a todos os seres-humanos, e que seria ela o instrumento mais adequado para a determinação de valores livremente aceitos por todos os homens.

O ponto central reside na busca de uma "constituição politicamente perfeita" - único estado no qual todas as capacidades naturais da humanidade poderiam ser

desde otra óptica, con idéntica pathos la tesis contraria, esto es, que fue el iusnaturalismo, en cuanto ética de la razón, el fundamento inspirador del clima liberal y democrático en el que surgieron los derechos del hombre".(PEREZ LUÑO, 1984, p. 300).

${ }^{113}$ ARENDT, Hannah. As origens do totalitarismo. Trad. Roberto Raposo, São Paulo: Companhia das Letras, 1989. A respeito, ver também LAFER, Celso. Hannah Arendt. Pensamento, persuasão e poder. São Paulo: Paz e Terra, 2003. 
plenamente desenvolvidas ${ }^{114}$. Trata-se, conforme já se disse, da idéia do direito cosmopolita, desenvolvida na obra $A$ paz perpétua, em que Kant afirma que "os povos da terra participam em graus diferentes de uma comunidade universal, que se desenvolveu a ponto de que a violação de um direito numa parte do mundo, repercute em todos os lugares" ${ }^{\prime 15}$, um direito que ultrapassa as comunidades nacionais e constitui-se em normas de uma comunidade planetária, global. Ademais, a paz perpétua somente poderia ser atingida à medida que tal direito cosmopolita guiasse o relacionamento entre os povos como uma explicitação da "idéia racional de uma comunidade geral pacífica, quase mesmo amigável, de todos os povos da terra"116.

O direito surge, nesse plano, como instrumento, legitimado pela racionalidade humana, que tem como função precípua a coordenação da relação entre as diferentes nações, tendo, assim, a racionalidade como justificativa para a idéia de direitos universais. Nesse contexto, a Declaração de 1789 constitui um bastião do projeto racional universalizante da modernidade; verdadeiro intento político cosmopolita, que proclamou direitos inalienáveis e universais, com vistas a ordenar e homogeneizar a civilização mundial.

A idéia de direito cosmopolita moderna, estaria, portanto, preocupada em retirar dos fenômenos sociais os elementos necessários para que se pudesse compreender em que medida as raízes dos direitos humanos encontram-se mais no campo da racionalidade e da moralidade do que no espaço da vontade do estado soberano. A grande crítica a esta teoria reside, aprioristicamente, no "seu caráter altamente etnocêntrico, na medida em que transforma, indevidamente, valores e concepções da sociedade de pertencimento em universais", conforme aponta Eberhard ${ }^{117}$, com o qual concordamos.

Todavia, entendemos que a noção de universalismo não deva ser simplesmente rechaçada, mas reformulada sobre novas bases, porquanto, de fato, entendemos que a universalidade não deva ser representada pela simples consagração de

\footnotetext{
${ }^{114}$ KANT, 1997, p. 33.

${ }^{115}$ Idem, ibidem, $2^{\mathrm{a}}$ seção, artigo terceiro definitivo, p. 140

${ }^{116}$ KANT, 1997, proposição 8, p. 33.

117 EBERHARD, Christoph. Direitos humanos e diálogo intercultural - uma perspectiva antropológica.. In: Baldi, César Augusto. Direitos humanos na sociedade cosmopolita. Rio de Janeiro: Renovar, 2004, p. 164.
} 
direitos considerados aprioríticos, como pretendiam os jusnaturalistas modernos. Busca-se, por sua vez, discutir a possibilidade de se encontrar uma fonte comum e universalizadora de direitos definida pela idéia de dignidade da pessoa humana, que seria um valor intrínseco à condição humana, cujo conteúdo, ademais, é culturalmente definido. "Defendese, nessa perspectiva, o mínimo ético irredutível - ainda que se possa discutir o alcance desse 'mínimo ético' e dos direitos nele compreendidos"118.

\subsection{Relativismo cultural.}

Contrapõe-se aos universalistas a teoria do relativismo cultural, sustentando, nas palavras de Vincent, referido por Piovesan, que as regras morais variam no tempo e espaço e que qualquer tentativa de universalização pode ser comparada a uma atitude imperialista que desrespeita a pluralidade de valores produzidos por culturas diversas:

Não há moral universal, já que a história do mundo é a história de uma pluralidade de culturas e, neste sentido, buscar uma universalidade, ou até mesmo o princípio de universalidade clamado por Kant, como critério para toda moralidade, é uma versão imperialista de tentar fazer com que valores de uma determinada cultura sejam gerais. [...] Há uma pluralidade de culturas no mundo e essas culturas produzem seus próprios valores ${ }^{119}$.

Cada sociedade, determinada por sua história e sua cultura, possuiria, portanto, seu próprio e peculiar discurso dos direitos humanos, conforme destacado por Piovesan (2006, p. 19):

Para os relativistas, a noção de direitos está estritamente relacionada ao sistema político, econômico, cultural, social e moral vigente em determinada sociedade. Cada cultura possui seu próprio discurso acerca dos direitos fundamentais, que está relacionado às específicas circunstâncias culturais e históricas de cada sociedade. Não há moral universal, já que a história do mundo é a história de uma pluralidade de culturas. Há uma pluralidade de culturas no

\footnotetext{
118 PIOVESAN, Flávia. Direitos humanos e justiça internacional. 1ª ed., São Paulo: Saraiva, 2006, p. 17

119 VINCENT, R.J. Human rights and international relations. p. 37/38. Apud PIOVESAN, Flávia. A universalidade e a indivisibilidade dos direitos humanos: desafios e perspectivas. In: BALDI, César Augusto. Direitos humanos na sociedade cosmopolita. Rio de Janeiro: Renovar, 2004, p. 61.
} 
mundo, e essas culturas produzem seus próprios valores. $\mathrm{Na}$ visão dos relativistas, os universalistas invocam a visão hegemônica da cultura eurocêntrica ocidental, na prática de um canibalismo cultural. Já para os universalistas, os relativistas, em nome da cultura, buscam acobertar graves violações a direitos humanos. Ademais, complementam, as culturas não são homogêneas, tampouco compõem uma unidade coerente; mas são complexas, variáveis, múltiplas, fluidas e não estáticas. São criações humanas e não destino.

Apresentam-se os direitos humanos, a partir de uma interpretação culturalista, como um elenco variável ao logo da história, contingente e diretamente influenciado por interesses das classes no poder, por valores sociais e pela disponibilidade dos meios necessários à sua realização. Além do mais, sublinha-se a previsão de que no futuro novos direitos resultem de novas necessidades sociais. Com efeito, a delimitação das dimensões de direitos, que foram, passo a passo, agregando distintos direitos fundamentais ao conjunto inicial dos direitos individuais constitui prova clara de que o que parece fundamental em uma época histórica e em uma determinada sociedade pode não ser fundamental em outras épocas ou grupos sociais.

Direitos historicamente relativos são, portanto, variáveis, e destes não é possível a extração de qualquer fundamento absoluto, o que talvez seja a chave para o desenvolvimento da garantia dos direitos humanos. A ilusão da existência de um fundamento absoluto tornaria impossível a introdução de novos direitos, incompatíveis com os primeiros, mas cuja garantia fosse necessária no novo contexto histórico. Não se pode olvidar que na história humana a única constante é a mudança social, fruto do conflito e força motriz do desenvolvimento das sociedades, que gera, por conseguinte, alteração na realidade econômico-social, no imaginário coletivo, nos valores aceitos e também nos direitos tidos como fundamentais.

Assim, Bobbio ${ }^{120}$ restou por concluir que a busca por um fundamento absoluto para os direitos fundamentais estaria fadada ao fracasso, e que mais importante do que tal busca seria a análise dos meios e das condições em que este ou aquele direito poderia ser realizado, almejando-se definir, desta forma, o modo mais eficaz de garantia e

${ }^{120}$ Cf. BOBBIO, 1992. 
realização dos direitos considerados, hoje, ou em outro contexto historicamente determinado, mais essenciais à vida humana.

Foucault, relativizou a própria idéia de ser humano: "uma invenção recente, uma figura que não tem nem dois séculos..." ${ }^{21}$, para demonstrar o quanto as propostas universalistas modernas partiam necessariamente de uma visão determinada da realidade e do homem, que havia nascido em local determinado: a Europa, e em um momento específico: a partir do iluminismo. Ademais, muitas vezes, o caráter universalista dos direitos humanos serviu para justificar um imperialismo cultural autoritário, com raízes no colonialismo, que apregoava a homogeneidade das civilizações através da universalização dos valores europeus.

Dentro da modernidade, a noção de progresso histórico unilinear contribuiu enormemente para que se identificasse a história da humanidade com aquela da Europa. Nas palavras de Davutoglu "a herança cultural e intelectual de outras civilizações é aceita como parte do fluxo histórico apenas no quadro de sua contribuição e de seu vínculo ao paradigma hegemônico existente da cultura ocidental"122. A própria filosofia ocidental: racionalista, teria se desenvolvido sobre a noção de que existe apenas um processo unidirecional para o progresso e a história e, de fato, “a versão mais acabada dessa idéia é a adoção do fim da história, o qual a supõe começando com o Ocidente e terminando por meio dele" ${ }^{\prime 123}$. A ciência incorpora essa racionalidade e durante toda a modernidade propõe a idéia de que a realidade seria única quando apreendida pela razão. Destarte, as civilizações não-ocidentais seriam meros coadjuvantes na história e suas explicações não científicas seriam desprovidas de qualquer valor.

Entretanto, não somente a história da humanidade, como nos é contada, apresenta caráter marcadamente eurocêntrico, mas também a geografia demonstra que apesar da Europa ocidental ser pequena em termos geográficos, consideramo-na um continente, localizado no centro do planisfério. Fernand Braudel, citado por Davutoglu

\footnotetext{
${ }^{121}$ FOUCAULT, Michel. As palavras e as coisas. São Paulo: Martins Fontes, 1995, p. 404.

${ }^{122}$ DAVUTOGLU, Ahmet. Cultura global versus pluralismo cultural: hegemonia civilizacional ou diálogo e interação entre civilizações. In: BALDI, César Augusto. Direitos humanos na sociedade cosmopolita. Rio de Janeiro: Renovar, 2004, p.123.

${ }^{123}$ DAVUTOGLU, 2004, p.123.
} 
(2004, p. 124), ao analisar o papel exercido pela geografia na formação da civilização islâmica, afirma que

os mapas contam a história essencial. [...] Cada civilização produziu seu próprio mapa, refletindo sua imaginação a respeito do mundo, e esses mapas foram utilizados para provar que a imagem subjetiva dos construtores da civilização sobre sua centralidade é um fato geográfico objetivo.[...]

Cada civilização desenvolve seu próprio mapa objetivo com base em sua imaginação subjetiva do outro.

A transposição de tal idéia significa a proposição de uma história dinâmica e múltipla, construída a partir da premissa de que a percepção humana da realidade insere-se em uma perspectiva temporal.

Essa educação eurocêntrica continuou a ser o único padrão global, mesmo após o final da era colonial. Assim sendo, um chinês, um indiano, um mulçumano, um nativo-americano ou um estudante africano passaram por uma lavagem cerebral por parte deste pressuposto globalizado de que seus ancestrais não contribuíram com coisa alguma para a história da humanidade, já que não há lugar para Confúncio, Farabi, Ibn Rushd, Liang Shu Ming, Iqbal, Ghandi ou Radhakrishnan nessa continuidade histórica. Mesmo que haja, o papel dessses pensadores é apresentado como válido para o nível local de sua civilização específica em vez de ser uma contribuição de valor global para a humanidade. (DAVOTOGLU, 2004, p. 123).

A busca da universalização dos direitos humanos e seus instrumentos de garantia seria, para os relativistas, resultado de um imperialismo cultural ocidental, que desconsidera as diferenças culturais e apregoa a homogeneização das sociedades a partir das crenças cristã-ocidentais ${ }^{124}$. O próprio conceito que temos de direitos humanos possui

\footnotetext{
${ }^{124}$ No mesmo sentido, sublinhamos as observações de Asmaron Legesse, citado por Piovesan, o qual afirma que "uma diferença crítica entre a África e as tradições ocidentais se refere à importância que esta última atribui aos indivíduos em si. Nas democracias liberais do mundo ocidental, o titular primeiro de direitos é a pessoa humana. $\mathrm{O}$ indivíduo assume uma posição quase sagrada. Há uma perpétua e obsessiva preocupação com a dignidade do indivíduo, seu valor, autonomia, e propriedade individual. [...] Escrevendo de uma perspectiva islâmica, no mesmo sentido, Ahmad Yamani observa que o ocidente é extremamente zeloso na defesa de liberdades, direitos e dignidade individual, enfatizando a importância de atos exercidos por indivíduos no exercício desses direitos, de forma a pôr em risco a comunidade". (PIOVESAN, 2004, p. 59).
} 
pressupostos antropológicos de cunho ocidental, como observa Boaventura de Sousa Santos:

existe uma natureza humana universal que pode ser conhecida racionalmente; a natureza humana é essencialmente diferente e superior à restante realidade; o indivíduo possui uma dignidade absoluta e irredutível que tem de ser defendida da sociedade ou do Estado; a autonomia do indivíduo exige que a sociedade esteja organizada de forma não hierárquica, como soma de indivíduos livres ${ }^{125}$.

Da mesma forma, Pureza, referindo-se a Prakashi Sinhá, ressalta que a formulação dos direitos humanos reflete valores ocidentais:

primeiro, na consideração do indivíduo e não da família, do clã, da tribo, da etnia como unidade fundamental da sociedade; depois, na concepção da inserção do indivíduo na sociedade através da afirmação de direitos e não pela vinculação a deveres; enfim, na configuração normativista formalista da organização racional da vida em sociedade, em detrimento de fatores como a tradição e a educação ${ }^{126}$.

Contra as críticas dos relativistas, os universalistas apontam graves casos de violação de direitos humanos que poderiam ser justificados através do argumento do relativismo cultural - que impossibilitaria qualquer punição por parte da comunidade internacional. O valor da dignidade humana, para os universalistas, deve ser preservado acima de quaisquer divergências culturais locais. Some-se, ainda, o argumento, sublinhado por Piovesan (2004, p. 62), de que

\footnotetext{
se diversos Estados optaram por ratificar instrumentos internacionais de proteção dos direitos humanos, é porque consentiram em respeitar tais direitos, não podendo se isentar do controle da comunidade internacional, na hipótese de violação desses direitos e, portanto, de descumprimento de obrigações internacionais.
}

\footnotetext{
${ }^{125}$ SANTOS, Boaventura de Sousa. Por uma concepção multicultural de direitos humanos.In:BALDI, César Augusto. Direitos humanos na sociedade cosmopolita. Rio de Janeiro: Renovar, 2004, p. 251.

126 PUREZA, José Manuel. Direito internacional e comunidade de pessoas: da indiferença aos direitos humanos. In: BALDI, César Augusto. Direitos humanos na sociedade cosmopolita. Rio de Janeiro: Renovar, 2004, p. 95.
} 
Ou seja, a maior crítica contra o relativismo exacerbado consiste na absolutização da diferença, que não é capaz de observar qualquer horizonte comum e "tende a se transformar em indiferença, aceitando e justificando tudo o que existe [..]" ${ }^{\prime 27}$.

Por outro lado, cumpre sublinhar que no contexto do pós-Segunda Guerra Mundial, os direitos humanos contaram com um discurso generoso e universalista, que coexistiu, entretanto, com atrocidades financiadas pelos mesmos Estados que eloqüentemente os haviam proclamado em 1948. O processo de descolonização da África mostra o quão inserida em disputas geopolíticas e econômicas esteve a temática dos direitos humanos e sua suposta universalidade. Nesse sentido, "escrevendo em 1981 sobre a manipulação da temática dos direitos humanos nos EUA pelos meios de comunicação, Richard Falk denuncia a dualidade entre uma 'política de invisibilidade' e uma 'política de supervisibilidade", como bem anota Boaventura de Sousa Santos (2004, p. 252). Ademais, todo o sistema internacional dos direitos humanos foi concebido em um cenário em que poucos Estados tinham participação efetiva, o que resultou na quase imposição de toda normatização produzida aos países que alcançaram sua independência após $1948^{128}$.

\subsection{Universalismo multicultural - uma proposta conciliatória.}

"As ideias iguais que nasceram em povos que não se conheciam devem ter um fundo comum de verdade". (Giambattista Vico)

Uma proposta conciliatória talvez seja possível caso formulemos a noção de universalidade a partir da vocação "moral única de todos os homens, que devem ser considerados como fins e não como meios, e que devem ter condições de vida que lhes permitam eleger livremente seus planos de vida", conforme anota Peces-Barba ${ }^{129}$. A dignidade da pessoa humana significa, então, que o homem, como ser comunicativo e participativo que é, deve construir consensos dialógicos, que respeitem a multiplicidade

\footnotetext{
${ }^{127}$ BALDI, César Augusto. As múltiplas faces do sofrimento humano: os direitos humanos em perspectiva intercultural. In: BALDI, César Augusto. Direitos humanos na sociedade cosmopolita. Rio de Janeiro: Renovar, 2004, p. 39.

${ }^{128}$ MONACO, Gustavo Ferraz de Campos. A proteção da criança no cenário internacional. Belo Horizonte: Del Rey, 2006, p. 123.
} 
cultural e a liberdade de valores de cada um. Um projeto intercultural desse tipo considera o caráter histórico dos direitos humanos compatível com a sua universalidade. Para Cançado Trindade "compreendeu-se finalmente que a universalidade é enriquecida pela diversidade cultural, a qual jamais pode ser invocada para justificar a denegação ou violação dos direitos humanos"130.

Donnelly, referido por Pureza, no mesmo sentido, defende seu objetivo de universalização dos direitos humanos, desde que não se trate, contudo de uma universalidade imperialista e hegemônica, mas que consinta a possibilidade de uma concepção dinâmica e multicultural de tais direitos. Nas suas palavras:

Meu princípio objetivo é explicitar e defender os direitos humanos como direitos universais. Eu sustento, contudo, que esses direitos sejam estáticos, imodificáveis ou absolutos; qualquer elenco ou concepção de direitos humanos e a idéia de direitos humanos por si mesma - apresenta uma especificidade cultural e contingente ${ }^{131}$.

Assim, apesar da proposição da universalidade dos direitos humanos ter contribuído, segundo entendimento de Panikkar $^{132}$, para que se ocultasse as origens históricas ocidentais de tais direitos, bem como suas especificidade ideológicas, tal ressalva não implica considerar indesejável uma universalização que respeite as diferenças culturais e de conceituação do ser-humano. Destacamos, então, a posição de Boaventura de Sousa Santos, que defende uma visão multicultural dos direitos humanos, de caráter emancipatório, que possua fundamento em um processo cultural dialógico. Nas suas palavras:

os direitos humanos têm que ser reconceptualizados como multiculturais. $\mathrm{O}$ multiculturalismo, tal como eu o entendo, é pré-condição de uma relação equilibrada e mutuamente potenciadora entre a competência global e a

${ }^{129}$ Vide PECES-BARBA, Gregório. Curso de derechos fundamentales: Teoría General. Madrid: Imprenta Nacional del Boletín Oficial del Estado, 1999, p. 312.

${ }^{130}$ CANÇADO TRINDADE, Antônio Augusto. A proteção internacional dos direitos humanos no limiar do Século XXI. In: Revista dos Estudantes de Direito da Universidade de Brasília. 1998, p. 173.

${ }^{131}$ DONELLY, Jack. Cultural relativism and universal human rights. Human Rights Quaterly, vol 6, n. 4, p. 12, apud PUREZA, 2004, p. 95.

${ }^{132} C f$. PANIKKAR, Raimundo. Seria a noção de direitos humanos um conceito ocidental? In: Baldi, César Augusto. Direitos humanos na sociedade cosmopolita. Rio de Janeiro: Renovar, 2004. 
legitimidade local, que constituem os dois atributos de uma política contrahegemônica de direitos humanos no nosso tempo ${ }^{133}$.

Piovesan (2006, p. 18) apresenta mesmo entendimento, afirmando a importância de um diálogo aberto intercultural, que reconheça a dignidade de cada ser humano e o direito à diversidade. Também Bhikhu Parekh, ilustre professor da London School of Economics, referido por Piovesan (2006, p. 18), defende um universalismo pluralista, não etnocêntrico, baseado no diálogo intercultural, cujo objetivo seja

alcançar um catálogo de valores que tenha a concordância de todos os participantes. A preocupação não deve ser descobrir valores, uma vez que os mesmos não têm fundamento objetivo, mas sim buscar um consenso em torno deles. [...] Valores dependem de decisão coletiva. Como não podem ser racionalmente demonstrados, devem ser objeto de um consenso racionalmente defensável. [...] É possível e necessário desenvolver um catálogo de valores universais não etnocêntricos, por meio de um diálogo intercultural aberto, no qual os participantes decidam quais os valores a serem respeitados. [...] Essa posição poderia ser classificada como um universalismo pluralista.

O diálogo intercultural sobre os direitos humanos não se restringe a uma visão meramente relativista. Não se trata de uma abordagem anti-universalista, mas de uma tentativa de enriquecimento da sociedade global, através de perspectivas culturais diversas, de modo a proporcionar novos horizontes para consensos éticos em temas que envolvem a humanidade como um todo. Um pluralismo benéfico tem como pressuposto o diálogo mútuo, que seja capaz de possibilitar a descoberta dos outros e de nós mesmos, do passado e do presente de cada um, de modo a sermos capaz de construir um futuro conjunto.

A realidade não pode ser reduzida à percepção que cada indivíduo, sociedade ou nação possui dela. Dessa forma, nenhuma cultura é capaz de se manifestar como representante da humanidade ou tentar resolver seus problemas a partir do que considera como certo ou errado.

Nenhum conceito, como tal, é universal, cada um sendo válido basicamente onde foi concebido. [...] Até mesmo os conceitos matemáticos

\footnotetext{
${ }^{133}$ Apud PIOVESAN, 2006, p. 17.
} 
demandam o conhecimento prévio de um campo limitado, definido pelos axiomas que postulamos. Aceitar a possibilidade de conceitos universais implicaria uma concepção estritamente racionalista da realidade. Mas, mesmo que isso representasse a verdade teórica, não seria o caso concreto, pois a humanidade apresenta, na verdade, uma pluralidade de universos de discurso. Aceitar o fato de que o conceito de direitos humanos não é universal, não significa, contudo, que ele não deva se tornar universal. (PANIKKAR, 2004, p. 217).

Panikkar propõe, portanto, que busquemos equivalentes homeomórficos para o conceito de direitos humanos e quaisquer questões de interesse global, como preservação do meio-ambiente ou a proteção do patrimônio genético humano. O homeomorfismo não seria o mesmo que analogia, mas a busca por topoi comuns que tornem possível o alcance de consensos dialógicos que digam respeito aos valores que se deve preservar.

Devemos cavar até encontrar um solo homogêneo ou uma problemática semelhante, devemos buscar o equivalente homeomórfico neste caso, do conceito de Direitos Humanos. Homeomorfismo não é o mesmo que analogia; ele representa um equivalente funcional específico, descoberto através de uma transformação topológica. É um tipo de analogia funcional existencial (PANIKKAR, 2004, p. 209).

Trata-se de uma rejeição do universalismo aistórico e do relativismo fechado, que entende ser impossível qualquer consenso entre culturas diferentes. Buscamse plataformas de equivalência através do que Boaventura de Sousa Santos chama de hermenêutica diatópica, também proposta por Panikkar, para quem a questão central reside em como entender os valores de uma sociedade a partir de topoi de outra. Não se advoga a elaboração de um modelo universal de resolução dos dilemas éticos da humanidade, mas a busca de consensos mínimos que permitam a mútua colaboração intercultural para a otimização de valores considerados fundamentais para culturas distintas.

Somos, portanto, convidados a pensar de forma fundamentalmente plural, reconhecendo que pode haver escolhas fundamentalmente diferentes que os homens fizeram para pensar sobre suas vidas e as organizar. Nessa perspectiva, nossa meta não pode ser mais a de elaborar um modelo explicativo universal, 
que tudo inclua, reduzindo tal diversidade a uma unidade artificial; ao contrário, deve ser a de encontrar formas de tornar nossos diferentes mitos mutualmente inteligíveis, permitindo assim sua fecundação mútua, sua articulação, sua mestiçagem. [...] É preciso reconhecer que a realidade não pode ser reduzida a um único centro de inteligibilidade (EBERHARD, 2004, p. 176).

O cerne da hermenêutica dialógica reside na premissa de que não há uma realidade unívoca; ela é percebida e influenciada por sujeitos que interagem e a apreendem segundo horizontes culturais diversos. Apesar do direito e da ciência ainda estarem impregnados da idéia moderna de que a realidade seguiria uma lógica racional e somente poderia ser conhecida através dessa mesma razão, a própria física quântica tem demonstrado que a realidade não passa de uma construção individual, presa aos preconceitos, valores e idéias que cada pessoa tem do que seja o mundo. Assim, “o diálogo dialógico é essencialmente um processo de descoberta mútua, podendo-se dizer que se situa no centro do empreendimento antropológico" ${ }^{\text {134. }}$.

Os valores não podem ser, portanto, transculturais, porque somente existem dentro de um contexto cultural específico, mas pode haver valores interculturais, como ressaltado por Panikkar (2004, p. 221). Nessa empreitada de conhecimento do outro, que é também um processo de auto-conhecimento, é necessário que exista alguma identificação com o objeto a ser conhecido, pois somente se é capaz de conhecer aquilo que se identifica como sendo algo ou integrante de um conjunto previamente estabelecido. Sem que exista qualquer semelhança, não é possível a compreensão. Destarte, o consenso dialógico, pelo convencimento, funda-se na identificação dos sujeitos participantes, inevitável, ainda que se dê tão-somente no que tange à preservação da espécie humana e à sua dignidade, enquanto ser humano.

Boaventura de Sousa Santos (2004, p. 254/255) destaca, então, cinco premissas, que constituiriam as bases de um diálogo intercultural construtivo, que contribuiria para que culturas diferentes pudessem alcançar consensos mínimos éticos sobre questões de relevância para a humanidade.

${ }^{134}$ EBERHARD, 2004, p. 177. 
A primeira premissa é a superação do debate sobre universalismo e relativismo cultural. Todas as culturas são relativas, mas o relativimo cultural, enquanto posição filosófica é incorreto. [...] Contra o universalismo, há que propor diálogos interculturais sobre preocupações isomórficas, isto é, sobre preocupações convergentes ainda que expressas e a partir de universos culturais diferentes. Contra o relativismo, há que desenvolver critérios que permitam distinguir uma política conservadora de direitos humanos, uma política de capacitação de uma política de desarme, uma política emancipatória de uma política regulatória. $\mathrm{Na}$ medida em que o debate desencadeado pelos direitos humanos pode evoluir para um diálogo competitivo entre culturas diferentes sobre os princípios de dignidade humana, é imperioso que tal competição induza as coligações transnacionais a lutar por valores ou exigências máximos. [...]

A segunda premissa da transformação cosmopolita dos direitos humanos é que todas as culturas possuem concepções de dignidade humana, mas nem todas elas a concebem em termos de direitos humanos. Torna-se, por isso, importante identificar preocupações isomórficas entre diferentes culturas.

A terceira premissa é que todas as culturas são incompletas e problemáticas nas suas concepções de dignidade humana.

A quarta premissa é que todas as culturas têm versões diferentes de dignidade humana, algumas mais amplas do que outras, algumas com um círculo de reciprocidade mais largo do que outras, algumas mais abertas a outras culturas do que outras.[...]

Por último, a quinta premissa é que todas as culturas tendem a distribuir as pessoas e os grupos sociais entre dois princípios competitivos de pertença hierárquica. Um $-\mathrm{o}$ princípio da igualdade [...]. $\mathrm{O}$ outro $-\mathrm{o}$ princípio da diferença - opera através da hierarquia entre identidade e diferenças consideradas únicas. Embora na prática os dois princípios se sobreponham frequentemente, uma política emancipatória de direitos humanos deve saber distinguir entre a luta pela igualdade e a luta pelo reconhecimento igualitário das diferenças a fim de poder travar ambas as lutas eficazmente. 


\section{A aplicacão da teoria do discurso como decorrência da aplicacão do}

princípio democrático.

Almejamos com este trabalho ressaltar a importância da ética na proteção dos direitos humanos e da bioética. Da atuação ética decorre a necessidade de que as decisões tomadas, especialmente no campo da medicina e da tecnologia aplicada à vida, sejam fruto de um consenso construído por meio do diálogo racional e consciente de pessoas livres, estabelecendo parâmetros éticos de atuação e proteção a valores fundamentais: vida, integridade física e psíquica, integridade do patrimônio genético, intimidade genética, igualdade e não discriminação - que podem vir a serem lesionados em virtude dos progressos biotecnológicos no campo da engenharia genética.

Partimos da noção de que os direitos humanos, reconhecidos como fundamentais, constituem o ethos democrático. Destarte, uma teoria discursiva insere-se, portanto, em um contexto em que o princípio democrático emerge como legitimador da constituição e do sistema normativo. Assim, em um Estado preocupado com a efetivação dos direitos humanos, o princípio da democracia, apresenta primacial relevância e conduz, segundo Habermas, com o qual concordamos, à teoria do discurso. Em suas palavras:

O princípio do discurso só pode assumir a figura de um princípio da democracia, se estiver interligado com um médium do direito, formando um sistema de direitos que coloca a autonomia pública numa relação de pressuposição recíproca [...]. Sendo que a compreensão discursiva do sistema de direitos conduz o olhar para dois lados: De um lado a carga da legitimação da normatização jurídica das qualificações dos cidadãos desloca-se para os procedimentos da formação discursiva da opinião e da vontade, institucionalizados juridicamente. De outro lado, a juridificação da liberdade comunicativa significa também que o direito é levado a explorar fontes de legitimação das quais ele não pode dispor ${ }^{135}$.

No mesmo sentido, manifesta-se Dalla Rosa:

Cumpre à constituição desempenhar o ponto de materialização dos valores sociais e de sua potencialidade, tanto pela via aberta e plurívoca dos princípios 
como pelo regramento ordenativo, concentrando em sua disposição normativa o momento histórico-cultural vivenciado por determinadas comunidades e captando as necessidades sócio-culturais de que dependem a concretização eficaz dos comandos normativo-constitucionais ${ }^{136}$.

É de se ver que a racionalidade do processo democrático é produto de "um jogo argumentativo travado dentro de um espaço público, procedimental e legitimador do próprio Estado de Direito [...] que pretende resgatar a normatividade constitucional possibilitada pela discussão em torno de uma racionalidade discursiva necessária à realização dos direitos fundamentais" ${ }^{\text {137. }}$. Visando, então, à efetivação de tais direitos, propugnamos a transposição da noção de direito e Estado fundada no positivismo estrito, a fim de ressaltarmos a idéia de razão substancial ${ }^{138}$, inserida na noção relativista dos valores, própria das sociedades contemporâneas em que se protege o pluralismo cultural. Nesse contexto, o objetivo do Estado constitucional deixa de ser tão somente a realização de um programa de direitos fundamentais previamente concebido, para prever a efetivação de um espaço público de discussão "e confrontação discursiva do grande número de projetos de vida e justiça que se contêm nele" ${ }^{\text {139 }}$.

Em um Estado que se propõe a ser democrático, as razões que justificam a aplicação de uma determinada norma no caso concreto apresentam relevante importância. Com efeito, propomos a utilização da teoria da argumentação para a solução dos questionamentos suscitados no âmbito da bioética, pois ela, claramente, visa à concretização dos direitos considerados fundamentais em uma ordem democrática, apresentando um procedimento de solução dos conflitos por meio de uma razão fundada no consenso, que permite a prolação de decisões consistentes, com aceitabilidade abrangente.

As teorias da argumentação jurídica partem dos trabalhos desenvolvidos por Viehweg, Toulmin, Perelman e Recanséns Siches, nos princípios dos anos cinqüenta do

135 HABERMAS, Jurgen. Direito e democracia, entre facticidade e validade. Trad. de Flávio Beno Siebeneichler-UFG, Rio de Janeiro: Biblioteca Tempo Universitário, 1997, vol. I, p. 165 e 168.

${ }^{136}$ DALLA-ROSA, Luiz Vergílio. Uma teoria do discurso constitucional. São Paulo: Landy, 2002, p. 232.

${ }^{137}$ DUARTE, Écio Oto Ramos. Teoria do discurso e correção normativa do direito. São Paulo: Landy, 2003, p. 48.

${ }^{138}$ Trata-se de uma razão substantiva, que considera o relativismo inerente à compreensão que cada indivíduo possui da realidade, ainda que condicionado por representações coletivas determinadas por uma sociedade histórica. 
século XX, e "inserem-se numa dimensão política de conexão com o denominado sentido profundo da democracia"140. De fato, relacionada à idéia de uma ética racional e universalista desenvolveu-se a ética do discurso, inserida "no círculo das ciências reconstrutivas que têm a ver com os fundamentos racionais do conhecer"141.

Reformulando as premissas kantianas, dois brilhantes professores da Universidade de Frankfurt, Karl-Otto Apel e Jürgen Habermas ${ }^{142}$ preconizaram uma ética discursiva.

O discurso pode ser definido como forma de comunicação mais exigente, direcionada para a formação de consensos universais, estabelecidos em uma comunidade ideal de sujeitos reciprocamente considerados iguais; espécie de comunicação que vai além das formas de vida concretas e "na qual as pressuposições do agir orientado pelo entendimento mútuo se universalizam, se abstraem e liberam de barreiras, estendendo-se a uma comunidade ideal de comunicação que inclui todos os sujeitos capazes de falar e de agir"143.

Para Habermas (2004, p. 78), “a formulação legal do imperativo categórico, que nos leva a vincular a vontade às máximas que todos podem querer como uma lei universal", determina, em uma nova perspectiva, que, em casos de conflito, "sujeitos que agem com autonomia precisam entrar no discurso para descobrir ou desenvolver juntos as normas que, com vistas a uma matéria que necessita de regulação, mereçam a aprovação fundamentada de todos"144. Assim é que a ética discursiva propõe uma formação de vontade guiada pela satisfação dos interesses particulares dos indivíduos "sem romper o

${ }^{139}$ DUARTE, 2003, p. 49.

${ }^{140}$ Idem, ibidem, p. 41.

${ }^{141}$ HABERMAS, Jürgen. Consciência moral e agir comunicativo. Trad. Guido A. de Almeida. Rio de Janeiro: Tempo brasileiro, 2003, p. 121.

${ }^{142}$ Podemos considerar Habermas e Apel filiados à corrente que preconiza uma ética discursiva, embora divirjam em certos pontos, consoante expôs o próprio Habermas em debate organizado na Universidade de Paris-Sorbonne em 2001. Segundo o próprio Habermas (2004, p. 23 e 29), "Karl-Otto ainda crê na existência de um meta-discurso racional de caráter transcendente e auto-referencial que garante uma posição privilegiada para a filosofia", enquanto ele teria optado por "um modelo hegeliano".

${ }_{143}$ GARCIA, Maria. Limites da ciência: a dignidade da pessoa humana, a ética da responsabilidade. São Paulo: Revista dos Tribunais, 2004, p. 237-238.

${ }^{144}$ HABERMAS, 2004, p. 78. 
vínculo social que une objetivamente a cada um deles com todos os demais"145. Do mesmo modo, para Apel, a argumentação deve reformular a teoria ética kantiana, fundando o que ele chama de "ética da discussão", mais adequada ao cenário pós-moderno: "sem Deus e cheio de almas mortais que se inter-relacionam não mais dentro de sistemas culturais grupais fechados (que sustentavam a ética solidária do passado), mas por meio de gigantescas redes tecnológicas e comerciais impessoais" ${ }^{\text {"146. }}$.

Partindo de um novo conceito de razão: dialógica, partilhada por atores lingüisticamente competentes, em contraposição à razão instrumental iluminista, Habermas e Apel desenvolveram a teoria da racionalidade comunicativa. "Neste sentido, Habermas e Apel procuram edificar as condições para uma ética universalista do discurso práticocomunicativo que objetive uma maior assimilação entre o 'eu'individual e a autonomia das vontades coletivas" ${ }^{" 147}$. Com base na razão comunicativa, buscam, dessarte, os filósofos alemães, uma saída para a crise da razão moderna, vez que "os pressupostos habermasianos não mais recorrem exclusivamente à razão, mas interpõem os princípios gerais da comunicação humana, dada pela vida concreta dos participantes"148.

De fato, a ética do discurso encontra-se inserida no grupo das éticas cognitivistas, as quais partem do imperativo categórico kantiano, distinguindo-se dele. Para Habermas (2003, p. 84), o que interessa é “a idéia subjacente que deve dar conta do caráter impessoal ou universal dos mandamentos morais válidos. O princípio moral é compreendido de tal maneira que exclui como inválidas as normas que não possam encontrar o assentimento qualificado de todos os concernidos possíveis". Como conseqüência, ele propõe a existência de um "princípio-ponte"149 entre as observações pessoais e as hipóteses universais do discurso prático, rejeitando recorrer ao processo de indução utilizado pelo discurso teórico. Referido princípio-ponte funda-se na idéia de que se deve buscar um consenso baseado na vontade universal que possa dar origem a uma lei universal. Trata-se da aplicação, pela ética do discurso, do imperativo categórico, devidamente reformulado, entendido como "um princípio que exige a possibilidade de

\footnotetext{
145 Apud GARCIA, 2004, p. 238.

${ }^{146}$ APEL, 1994, p. 213.

${ }^{147}$ Revista Seqüência, n. 26, 1993, Florianópolis: DAUFSC, p. 53.

${ }^{148}$ Idem, ibidem.
} 
universalizar as maneiras de agir e as máximas ou antes, os interesses que elas levam em conta" $" 150$.

É certo, por outro lado, que o universalismo proposto por Kant, monológico $^{151}$, é questionável e que, de fato, muitas das críticas opostas pelos adeptos do relativismo cultural são plausíveis, como bem já expusemos nesse trabalho, vez que a idéia do que seja universalizável para um sujeito, baseia-se em valores próprios da sua cultura. Habermas ${ }^{152}$ refere-se, nesse sentido, às objeções apresentadas por Paul Taylor, de que "em face das evidências antropológicas, temos que admitir que o código moral que as teorias morais kantianas interpretam é apenas um entre muitos"153. Nas palavras do autor americano: "por mais que profundamente nossa própria consciência e perspectiva moral possa ter sido moldadas por ele, temos que reconhecer que outras sociedades na história do mundo puderam funcionar com base em outros códigos" $" 154$.

Haveria, então, a desconfiança de que toda pretensão de universalidade não passaria de uma falácia etnocêntrica. Não se discorda de que o universalismo proposto por Kant, repise-se, monológico ${ }^{155}$, seja indefensável nas sociedades democráticas atuais. Contudo, o que as teorias mais modernas propõem, como o faz Habermas com a ética do discurso, é tentar reconstruir o "saber pré-teórico""156.

Com efeito, da constatação da existência de um pluralismo axiológico intrínseco às sociedades contemporâneas, afirma a necessidade da existência "de um princípio-ponte que possibilite o consenso" 157 frente ao relativismo cultural. Habermas

\footnotetext{
${ }^{149}$ HABERMAS, 2003, p. 84.

${ }^{150}$ Idem, ibidem, p. 84.

151 Nesse sentido anota Habermas (2003, p. 88) que "As necessidades são interpretadas à luz de valores culturais; e como estes são sempre parte integrante de uma tradição partilhada intersubjetivamente, a revisão dos valores que presidem à interpretação das necessidades não pode de modo algum ser um assunto do qual os indivíduos disponham monológicamente".

152 Importante destacar que Habermas (2004, p. 09) reconhece a contingência produzida pelo pluralismo cultural ao afirmar que "o mundo se revela e é interpretado de modo diferente segundo as perspectivas dos diversos indivíduos e grupos”.

${ }_{153}$ Apud HABERMAS, 2003, p. 100.

154 Apud HABERMAS, 2003, p. 100.

155 É certo que, diante da complexidade e do pluralismo presente nas sociedades modernas, os problemas morais emergentes não podem ser solucionados monologicamente, exigindo, ao contrário, verdadeira cooperação - que garanta a validez normativa necessária.

${ }^{156} C f$. HABERMAS, 2003, p. 100/101.

${ }^{157}$ Idem, ibidem, p. 98.
} 
propõe, consoante já explicitado, que o princípio da universalização " $U$ ” funcione como ponte para os acordos intersubjetivos. Porém, contra essa proposta, é sempre possível oporse a crítica de que se busca uma generalização dos valores ocidentais por meio de um universalismo imperialista.

Em resposta à referida crítica, é de se ressaltar que o princípio $d a$ universalização proposto por Habermas visa a que um consenso possa ser alcançado intersubjetivamente, ou seja, de forma dialógica ${ }^{158}$ : ponto central que o distingue da teoria kantiana pura, porquanto a ética discursiva propõe a transição da "reflexão monológica para o diálogo" "159 , de modo a possibilitar a idéia de universalização. As pretensões normativas preconizadas por meio do discurso são universalizáveis em razão de todos os sujeitos concernidos aceitarem as conseqüências e efeitos colaterais dela advindos. Dessarte, é claro que referida proposta de universalização distingue-se daquela de John Rawls, consoante explica, de forma clara, Habermas (2003, p. 87):

Este [John Rawls] gostaria de ver assegurada a consideração imparcial de todos os interesses afetados pela iniciativa do sujeito, que julga moralmente, de colocarse num estado originário fictício excluindo os diferenciais de poder, garantindo liberdades iguais para todos e deixando cada um na ignorância das posições que ele próprio assumiria numa ordenação social futura, não importa como organizada. Como Kant, Rawls operacionaliza de tal maneira o ponto de vista da imparcialidade que cada indivíduo possa empreender por si só a tentativa de justificar normas básicas. Isso vale também para os filósofos morais eles próprios. Conseqüentemente, Rawls entende a parte material de sua própria investigação, por exemplo o desenvolvimento do princípio do benefício médio, não como uma contribuição de um participante da argumentação para a formação discursiva da vontade acerca das instituições básicas de uma sociedade capitalista avançada, mas justamente como resultado de uma 'teoria da justiça' para qual ele tem uma competência a título de especialista.

\footnotetext{
${ }^{158} \mathrm{O}$ princípio de universalização segundo a ética do discurso não tem por base, portanto, uma reflexão monológica, segundo a qual determinadas máximas seriam consideradas leis universais segundo um ponto de vista individual.

159 HABERMAS, Jürgen. A ética da discussão e a questão da verdade. $1^{\text {a }}$ edição. São Paulo: Martins Fontes, 2004b, p. 08/09
} 
A ética do discurso consiste em reflexão intersubjetiva por meio de argumentações direcionadas ao "agir orientado para o entendimento mútuo" "160, alicerçado no "reconhecimento mútuo de sujeitos imputáveis"161. Para Habermas (2003, p. 87), o processo argumentativo visa a "dirimir consensualmente os conflitos da ação" - os quais, a seu turno, resultariam, nessa perspectiva, de um acordo normativo perturbado, que somente é reconstruído com o reconhecimento intersubjetivo da validez de uma norma, com base no consenso e na vontade comum ${ }^{162}$.

Assim, resta clara a necessidade de que se valorize e implemente um processo argumentativo real, do qual todas as pessoas envolvidas possam, de certa maneira, participar, pois somente através do "entendimento mútuo intersubjetivo", pode-se alcançar "um acordo que é de natureza reflexiva", por meio do qual "os participantes podem saber que eles chegaram a uma convicção comum" ${ }^{\text {"63. E }}$. justamente com a proposição de um espaço público de discussão e reflexão, no qual possam ser alcançados consensos intersubjetivos, é que Habermas (2003, p. 88), embora parta da noção do imperativo categórico, apresenta-lhe nova formulação: "Ao invés de prescrever a todos os demais como válida uma máxima que eu quero que seja uma lei universal, tenho que apresentar minha máxima a todos os demais para o exame discursivo de sua pretensão de universalidade". De fato, através do discurso, “o peso desloca-se daquilo que cada (indivíduo) pode querer sem contradição como lei universal para aquilo que todos queiram de comum acordo reconhecer como norma universal” ${ }^{164}$.

Ademais, Habermas (2003, p. 86) relaciona imparcialidade com universalidade, afirmando que "só é imparcial o ponto de vista a partir do qual são passíveis de universalização exatamente aquelas normas que, por encarnarem manifestamente um interesse comum a todos os concernidos, podem contar com o assentimento universal - e, nesta medida, merecem reconhecimento intersubjetivo". Propõe, por isso, a adoção do princípio da universalização, que "força cada um, no círculo dos concernidos, a adotar,

\footnotetext{
${ }^{160}$ HABERMAS, 2003, p. 123.

${ }^{161}$ Idem, ibidem, p. 123.

162 Idem, ibidem, p. 87/88.

${ }^{163}$ Idem, ibidem, p. 88.

${ }^{164}$ Idem, ibidem, p. 88.
} 
quando da ponderação dos interesses, a perspectiva de todos os outros " ${ }^{165}$, de modo que toda norma válida satisfaça a condição de um "universal discourse" ou "ideal role-taking" (“adoção ideal de papéis") descrito por H. Mead, referido por Habermas (2003, p. 86), como o procedimento por meio do qual todos os participantes do discurso possam aceitar todas "as conseqüências e efeitos colaterais, que (previsivelmente) resultarem para a satisfação dos interesses de cada um dos indivíduos do fato de ser ela universalmente seguida". Em síntese, para Habermas (2003, p. 109/110), "todo aquele que aceita as pressuposições comunicacionais universais necessárias do discurso argumentativo e que sabe o que quer dizer justificar uma norma de ação tem que presumir implicitamente a validade do princípio da universalização".

O princípio da universalização habermasiano funda-se, portanto, na argumentação cooperativa realizada intersubjetivamente, vez que "só uma efetiva participação de cada pessoa concernida pode prevenir a deformação de perspectiva na interpretação dos respectivos interesses próprios pelos demais. Nesse sentido pragmático, cada qual é ele próprio a instância última para a avaliação daquilo que é realmente de seu próprio interesse" ${ }^{166}$. Dentro da noção de cooperação, cumpre, entretanto, distinguir o agir estratégico do agir comunicativo: "enquanto que no agir estratégico um atua sobre o outro para ensejar a continuação desejada de uma interação, no agir comunicativo um é motivado racionalmente pelo outro para uma ação de adesão"167.

Ressalva Habermas (2003, p. 84), contudo, que "o princípio da universalização não se esgota absolutamente na exigência de que as normas morais devem ter a forma de proposições deônticas universais e incondicionais". Até porque, considerando-se que "as circunstâncias históricas mudam, cada época lança sua própria luz sobre as representações básicas de natureza moral-prática"168. São propostas, então, regras pragmáticas procedimentais, aplicáveis “às questões práticas que podem ser debatidas racionalmente, e isso com a perspectiva de consenso. Ela não tem a ver com a preferência

\footnotetext{
${ }^{165}$ HABERMAS, 2003, p. 86.

${ }^{166}$ Idem, ibidem, p. 88.

${ }^{167}$ Idem, ibidem, p. 79.

${ }^{168}$ Idem, ibidem, p. 109.
} 
de valores, mas com a validez deôntica de normas de ação"169 . É certo, com efeito, que as pretensões de validade invocadas no discurso encontram-se inseridas em um contexto determinado no espaço e no tempo, porquanto apregoadas por seres humanos, contudo, tal limitação não invalida as razões expostas pelos participantes na busca de um acordo comunicativo, pois fundadas nas regras do discurso, as quais são universalizáveis ${ }^{170}$.

As ações intersubjetivas são chamadas pelo filósofo alemão de comunicativas quando "as pessoas envolvidas se põem de acordo para coordenar seus planos de ação"171. Este acordo, por sua vez, é alcançado pelo "reconhecimento intersubjetivo das pretensões de validez"172. A validez social de uma norma não é garantida pela sua simples edição positivista. A imposição duradoura não prescinde da possibilidade de que, em um dado contexto, razões possam ser invocadas pelo conjunto de indivíduos aos quais se endereçam, para legitimação do diploma normativo, porquanto, para Habermas (2003, p. 86), "as normas válidas têm que merecer o reconhecimento por parte de todos os concernidos". Assim é que "um consenso normativo, formado em condições de participação livre e universal no contexto de um discurso prático, estabelece uma norma válida (ou confirma a sua validade). A 'validade' de uma norma moral significa que ela 'merece' o reconhecimento universal em virtude de sua capacidade de, por meio da razão somente, obter o consentimento da vontade daqueles a quem se dirige" ${ }^{, 173}$.

Desse modo, tendo em vista que o principal objetivo do processo discursivo é produzir argumentos concludentes, que sejam "capazes de convencer com base em propriedades intrínsecas e com os quais se possam resgatar ou rejeitar pretensões de validez" ${ }^{174}$, são adotadas por Habermas (2003, p. 110) as regras lógicas e semânticas propostas por Robert Alexy ${ }^{175}$, consideradas pressupostos do processo argumentativo, as quais não possuem, contudo, qualquer conteúdo ético. Trata-se da enumeração de pressupostos universais e necessários da argumentação, que ultrapassam o horizonte de

\footnotetext{
${ }^{169}$ HABERMAS, 2003, p. 126/127.

${ }^{170}$ Idem, ibidem, p. 34.

${ }^{171}$ Idem, ibidem, p. 79.

${ }^{172}$ Idem, ibidem, p. 79.

${ }^{173}$ HABERMAS, 2004, p.65/66.

${ }^{174}$ HABERMAS, 2003, p. 110.

${ }^{175}$ Cf. ALEXY, Robert. Teoria da argumentação jurídica - A teoria do discurso racional como teoria da justificação jurídica. Trad. Zilda Hutchinson Schild Silva. 2a ed. São Paulo: Landy, 2005, p. 191.
} 
uma cultura determinada e que funda a ética do discurso como teoria procedimental. Vejamos:

(1.1) A nenhum falante é lícito contradizer-se.

(1.2) Todo falante que aplicar um predicado $\mathrm{F}$ a um objeto $a$ tem que estar disposto a aplicar F a qualquer outro objeto que se assemelhe a $a$ sob todos os aspectos relevantes.

(1.3) Não é lícito aos diferentes falantes usar a mesma expressão em sentidos diferentes ${ }^{176}$.

Trata-se de regras procedimentais para regulação das argumentações, compreendidas como processos de entendimento mútuo, a fim de que, como bem destaca Habermas (2003, p. 110/111), "proponentes e oponentes possam, numa atitude hipotética e liberados da pressão da ação e da experiência, examinar as pretensões de validez que se tornaram problemáticas". As regras propostas por Alexy podem ser, então, entendidas como pressupostos pragmáticos para a busca de um consenso cooperativo: uma verdade intersubjetiva. Nas palavras de Atienza, a validade de tais regras “é condição para qualquer comunicação linguística em que se trate da verdade ou da correção. [...] Essas regras enunciam os princípios de não contradição, sinceridade, universalidade" ${ }^{\text {177 }}$.

Neste plano, somam-se as regras gerais de competência e relevância para a distribuição dos encargos de argumentação ${ }^{178}$ que "incluem o reconhecimento da imputabilidade e da sinceridade de todos os participantes" ${ }^{179}$. São elas:

(2.1) A todo falante só é lícito afirmar aquilo que ele próprio acredita.

(2.2) Quem atacar um enunciado ou norma que não for objeto da discussão tem que indicar razões para isso ${ }^{180}$.

\footnotetext{
${ }^{176}$ HABERMAS, 2003, p. 110 e ALEXY, 2005, p. 191.

${ }^{177}$ ATIENZA, Manuel. As razões do Direito - Teorias da argumentação jurídica Perelman, Viehweg, Alexy, MacCormick e outros. Trad. Maria Cristina Guimarães Cupertino, São Paulo: Landy, 2003, p. 166.

${ }^{178}$ HABERMAS, 2003, p. 110/111.

${ }^{179}$ Idem, ibidem, p. 110/111.

${ }^{180}$ HABERMAS, 2003, p. 110/111 e ALEXY, 2005, p. 195.
} 
Considerando-se, com efeito, que o discurso argumentativo possui, em síntese, como principal objetivo a busca de uma acordo racionalmente motivado, neutralizado contra a repressão e a desigualdade, é certo que o processo de argumentação deve excluir do procedimento decisório toda coerção externa, admitindo, assim, tão somente, a "coerção do argumento melhor"181, proposto em um contexto de busca cooperativa da verdade, pois são premissas da ética do discurso as "condições universais de simetria que todo falante competente, na medida em que pensa entrar de todo numa argumentação, tem que pressupor como suficientemente preenchidas"182.

Nas palavras de Atienza (2003, p. 166):

O segundo grupo são as regras de razão, que definem as condições mais importantes da racionalidade do discurso. A primeira delas pode ser considerada 'a regra fundamental de fundamentação', e as outras três contêm os requisitos da situação ideal de fala ou de diálogo habermasiana, isto é, de igualdade de direitos, universalidade e não coerção. Com relação a questões práticas, essas regras só são cumpridas de modo aproximado: elas definem um ideal, do qual se deve aproximar por meio da prática e de medidas organizadoras.

Nesse cenário, Alexy (2005, p. 195) propôs, ainda, as seguintes regras do discurso - adotadas, outrossim, por Habermas (2003, p. 112):

(3.1) É lícito a todo sujeito capaz de falar e agir participar de Discursos.

(3.2) a. É lícito a qualquer um problematizar qualquer asserção.

b. É lícito a qualquer um introduzir qualquer asserção no Discurso.

c. É lícito a qualquer um manifestar suas atitudes, desejos e necessidades.

(3.3) Não é lícito impedir falante algum, por uma coerção exercida dentro ou fora do Discurso, de valer-se de seus direitos estabelecidos em (3.1) e (3.2).

\footnotetext{
${ }^{181}$ HABERMAS, 2003, p. 112.

${ }^{182}$ Idem, ibidem, p. 111.
} 
No que pertine a tais regras, Habermas (2003, p. 112) apresenta as seguintes explicações, importantes para a compreensão do processo pragmático discursivo proposto:

A regra (3.1) determina o círculo dos participantes potenciais no sentido de uma inclusão de todos os sujeitos, sem exceção, que disponham da capacidade de participar em argumentações. A regra (3.2) assegura a todos os participantes chances iguais de contribuir para a argumentação e de fazer valer seus próprios argumentos. A regra (3.3) exige condições de comunicação que tornem possível o prevalecimento tanto do direito a um acesso universal ao Discurso, quanto do direito a chances iguais de participar dele, sem qualquer repressão, por sutil e dissimulada que seja (e, por isso, de maneira igualitária).

Não se deve olvidar, por outro lado, que os sujeitos são movidos por outros motivos além "da busca cooperativa da verdade"183, de modo que se deve adotar instrumentos institucionais que sejam capazes de neutralizar as influências externas às regras do discurso, propugnando uma situação ideal de fala, a qual "exclui as distorções sistemáticas da comunicação. E a estrutura da comunicação só deixa de gerar coações se, para todo participante do discurso é dada uma distribuição simétrica das oportunidades de escolher e executar atos de fala" ${ }^{\text {184 }}$. Nesse sentido, instituições de controle como o judiciário e os comitês de ética cumprem relevante papel no âmbito da bioética.

É certo, em outra perspectiva, que, ao apresentar referidos pressupostos do discurso sob a forma de regras, Alexy almeja a que sejam sempre observadas, como verdadeiros mandamentos defintivos. Todavia, como bem ressalva Habermas, trata-se de regras que guiam o discurso, sendo, porém, possível a prática argumentativa sem que se satisfaça a essas regras, porquanto "as regras do Discurso são apenas as pressuposições pragmáticas, feitas tacitamente e sabidas intuitivamente, de uma prática discursiva privilegiada" $" 185$.

Quanto às objeções à ética do discurso, o próprio Habermas (2003, p. 125) faz referência a A. Wellmer, que se opõe à referida teoria aduzindo que:

\footnotetext{
${ }^{183}$ HABERMAS, 2003, p. 115.

184 HABERMAS, Jurgen, Teorías de la verdad. In: Habermas, J. Teoría de la acción comunicativa; complementos y estudios previos. Trad. M. Jiménez. Madrid: Cátedra, 1989, p. 153.

${ }^{185}$ Idem, ibidem, p. 114.
} 
É apenas na aparência que conseguimos, com a idéia de um 'Discurso isento de dominação' um padrão objetivo com que 'medir' a racionalidade prática de indivíduos ou sociedades. Na realidade seria uma ilusão crer que poderíamos nos emancipar da facticidade, por assim dizer normativamente carregada, de nossa situação histórica, com todo o legado de normas e critérios de racionalidade nela presentes, a fim de lançar um olhar, como que 'de lado' para a história como um todo e para a nossa posição dentro dela. Uma tentativa nessa direção só poderia terminar na arbitrariedade teórica e no terror prático.

Contra tal objeção, Habermas apresenta as razões a seguir. Primeiramente, que a ética do discurso constitui um procedimento preconizado para que se possa alcançar um consenso sobre validez normativa - o que, claramente, conduz à conclusão de que se trata de uma teoria formal. Ou seja, a ética do discurso não propõe orientações axiológicas, mas um processo que seja capaz de, em um determinado grupo social, inserido em um horizonte de vida específico, garantir que seja empreendido um discurso prático racional e democrático. Os participantes regularão a matéria controversa segundo o consenso alcançado, que garantirá validez ao acordo normativo perturbado.

Nas próprias palavras de Habermas (2003, p. 126),

\footnotetext{
"formal, por conseguinte, esse procedimento não o é no sentido da abstração de conteúdos. Em sua abertura, o Discurso precisa justamente que os conteúdos 'dêem entrada' nele. Todavia, esses conteúdos serão processados no Discurso de tal sorte que os pontos de vista axiológicos particulares acabem por ser deixados de lado, na medida em que são passíveis de consenso".
}

Demais disso, o princípio da universalização funciona como marco divisor entre "enunciados valorativos e enunciados estritamente normativos" ". Ao diferenciar as duas espécies de enunciados, Habermas (2003, p. 126/127) anota, quanto ao primeiro, que, baseado no plano axiológico, encontra-se tão relacionado com uma determinada vida particular, que não pode pretender uma "validez normativa no sentido estrito" 187 ,

\footnotetext{
${ }^{186}$ HABERMAS, 2003, p. 126/127.

${ }^{187}$ Idem, ibidem, p. 126/127.
} 
candidatando-se, contudo "a materializar-se em normas que dêem vez a um interesse universal" ${ }^{188}$.

Destarte, ainda que seja certo que o respeito pelas regras do discurso propostas não conduz a que uma única resposta seja alcançada, pois "diante de um mesmo caso, as regras do discurso jurídico permitem que seus vários participantes cheguem a soluções incompatíveis entre si, mas racionais (isto é, fundamentadas discursivamente)", como bem anota Atienza (2003, p. 179), não é menos certo que "o procedimento discursivo cumpre pelo menos uma função negativa: a de assinalar limites que não podem ser ultrapassados", consoante reconhece Atienza (2003, p. 180) ao comentar a obra de Habermas e Alexy.

Há, contudo, uma possível segunda objeção à teoria do discurso. Consiste na recusa daquele que Habermas chama de céptico em participar do discurso. Nesse caso, de recusa consciente de participação em processos argumentativos, entende Apel, ao qual se refere Habermas (2003, p. 108), que o sujeito, em verdade, já se engajou em um jogo argumentativo. Para ambos os autores, o que ocorreria é a renúncia do indivíduo "à sua qualidade de membro da comunidade dos que argumentam" ${ }^{189}$, fato que não deslegitima as pretensões de validez normativas alcançadas discursivamente, pois "pela recusa da argumentação ele não pode, por exemplo, nem mesmo indiretamente, negar que comparte uma forma de vida sócio-cultural, que cresceu em contextos do agir comunicativo e aí reproduziu sua vida"190. Ou seja, o indivíduo não pode "desvencilhar-se da prática argumentativa do quotidiano, na qual está obrigado continuamente a tomar posição por 'sim' ou por 'não'; na medida em que continua simplesmente a viver, não é possível imaginar sequer a título de experiência fictícia uma binsonada com que o céptico conseguisse demonstrar de maneira muda e impressiva seu salto para fora do agir comunicativo" ${ }^{\prime 191}$. Do contrário, seria necessário que ele se refugiasse no suicídio ou em grave doença mental, pois é certo que, intuitivamente, os sujeitos agem e buscam o estabelecimento de consensos comunicativos.

\footnotetext{
${ }^{188}$ HABERMAS, 2003, p. 126/127.

${ }^{189}$ Idem, ibidem, p. 122/123.

${ }^{190}$ Idem, ibidem, p. 122/123.

${ }^{191}$ Idem, ibidem, p. 123.
} 
Para Habermas (2003, p. 123), portanto,"não existe nenhuma forma de vida sócio-cultural que não esteja, ao menos implicitamente, orientada para o prosseguimento do agir comunicativo com meios argumentativos - por mais rudimentar que tenha sido o desenvolvimento das formas de argumentação e por mais pobre que tenha sido a institucionalização dos processos discursivos de entendimento mútuo", porquanto, para ele, com o qual concordamos, "não nos é possível sair do círculo da 'nossa' linguagem"192, pois o homem não possui "acesso imediato a uma realidade não interpretada ou 'nua",193, vez que, certamente, "não existe uma linguagem do mundo - um livro da natureza que se imporia aos nossos espíritos. Só existem as linguagem que inventamos a partir de diversos pontos de vista"194.

Finalmente, anota Habermas (2003, p. 128/129) que "os discursos práticos assemelham-se, como todas argumentações, a ilhas ameaçadas de se verem submersas pelas ondas no oceano de uma prática onde o modelo da solução consensual dos conflitos da ação não é de modo algum dominante". Refere-se o autor alemão ao fato de que os meios de coação e violência ainda predominam em muitos países, impedindo a construção de um consenso fundado sobre as bases da democracia. É justamente por isso, que são necessárias regras para o discurso, com base nas quais se possa verificar o grau de liberdade e reciprocidade concedido aos participantes concernidos.

\section{A teoria do discurso aplicada à bioética.}

\subsection{Casos de colisão de princípios.}

Conforme já destacado no curso deste texto, os princípios da bioética representaram a busca pela construção de uma ética normativa prática capaz de orientar médicos e cientistas sobre o que seria eticamente razoável diante dos novos questionamentos suscitados pelos avanços da ciência, especialmente no campo da genética

- que fizeram surgir dúvidas até então inexistentes. Estabelecem uma relação de

\footnotetext{
${ }^{192}$ HABERMAS, 2004, p. 55.

${ }^{193}$ Idem, ibidem, p. 55.

${ }^{194}$ Idem, ibidem, p. 58.
} 
complementariedade entre si, podendo ser considerados válidos tão somente prima facie conforme terminologia introduzida por Ross ${ }^{195}$ e outrossim adotada por Alexy ${ }^{196}$.

Destarte, tendo em vista a busca da máxima realização de cada princípio definidor de um direito considerado fundamental ao ser-humano, e de todos ao mesmo tempo, casos concretos de colisão de princípios são inevitáveis.

Na maioria das vezes, para solucionar essas situações, médicos, comitês de ética e cientistas, tradicionalmente, acabam recorrendo à análise de casos semelhantes, discutindo quais teriam sido as atitudes tomadas em contextos análogos. Chamamos essa técnica - desenvolvida durante a idade média - de casuística.

No entanto, concordamos com Schramm ${ }^{197}$ quando afirma que a referência a modelos pré-estabelecidos é problemática quando se trata de casos inéditos - o que tem ocorrido freqüentemente no campo da biomedicina e biotecnologia. Ou seja, não raramente, o rol de decisões anteriores não é suficiente para oferecer respostas às questões emergentes no âmbito da bioética. Além disso, deve-se considerar a natureza contingente da realidade concreta, suas especificidades inerentes, que tornam imprudente a decisão por analogia. Até porque o conteúdo dos princípios fundamentais é alterável ao longo dos anos e deve ser reavaliado segundo os valores próprios de uma sociedade determinada no tempo e espaço. Durand (2003, p. 222/223) ressalta que "deve-se julgar caso a caso levando em conta a importância dos valores em jogo[...]. Não há hierarquia preestabelecida, mas procura-se evitar o relativismo e a arbitrariedade".

Propomos, então, a aplicação da regra da proporcionalidade, conforme exposta por Robert Alexy: método analítico e determinado para solucionar os casos de colisão de princípios, baseado no exercício de uma ponderação que estabeleça uma relação de precedência condicionada entre eles, aplicável a uma situação concretamente determinada. Trata-se de metodologia já utilizada em âmbito jurídico e de grande valia à

\footnotetext{
195 ROSS, 1930.

${ }^{196}$ Cf.ALEXY, 1993.

${ }^{197}$ SCHRAMM, Fermin Roland. Os princípios da bioética. In: Marco Segre (org). Aquestão ética e a saúde humana. São Paulo: Atheneu, 2006, p. 18.
} 
resolução de situações de questões emergentes no âmbito da bioética, seja pelos Tribunais quanto pelos Comitês de Ética em pesquisa.

Em meados da década de 80, Robert Alexy apresentou uma teoria dogmática estrutural, idealizada para a aplicação em casos de colisão de direitos fundamentais. Tal teoria estrutural possui como base fundamental a teoria dos princípios. Busca este jurisfilósofo reabilitar a teoria dos valores fundamentais, revisitando-a e dando a ela um caráter de universalidade paradigmática. Para tanto, é pressuposta a distinção entre princípios e regras: “com ela, é possível a formulação de uma teoria dos limites, uma teoria satisfatória da colisão e uma teoria sobre o papel dos direitos fundamentais no sistema jurídico" ${ }^{\prime 198}$.

Alexy (1993, p. 86/87) esposa a tese de que há normas-princípios e normasregras, entre as quais haveria diferença qualitativa, sendo que:

\begin{abstract}
O ponto decisivo para a distinção entre regras e princípios é que os princípios são normas que ordenam que algo seja realizado na maior medida possível, dentro das posibilidades jurídicas e fáticas existentes. Portanto, os princípios são mandados de otimização, caracterizados pelo fato de que podem ser cumplidos em diferentes Graus e que a medida de seu cumplimento não só depende das posibilidades fáticas como também das jurídicas. [...] Diversamente, as regras são normas que só podem ser cumpridas ou não. Se uma regra é válida, então se debe fazer exatamente o que ela exige, nem mais nem menos ${ }^{199}$.
\end{abstract}

Para as regras, a aplicação ao caso concreto se dá através da subsunção. Entretanto, os princípios, quando aplicados a um caso concreto, dependem das possibilidades jurídicas e fáticas, necessitando de sopesamento.

\footnotetext{
198 STEINMETZ, Wilson Antônio. Colisão de direitos fundamentais e princípio da proporcionalidade. Porto Alegre: Livraria do Advogado, 2001, p. 123.

199 Tradução livre de: "El punto decisivo para la distinción entre reglas y principios es que los principios son normas que ordenan que algo sea realizado en la mayor medida posible, dentro de las posibilidades juridicas y reales existentes. Por lo tanto, los principios son mandados de optimización, que están caracterizados por el hecho de que pueden ser cumplidos en diferente grado y que la medida debida de su cumplimiento no sólo depende de las posibilidades reales sino también de las juridicas. [...] En cambio, las reglas son normas que sólo pueden ser cumplidas o no. Si una regla es valida, entonces de hacerse exactamente lo que ella exige, ni más ni menos".
} 
Um conflito de regras pode, portanto, ser solucionado através da declaração de invalidez de uma delas, o que se dá, basicamente, de duas maneiras: i. com a introdução de uma cláusula de exceção em uma das regras ou ii. declarando-se a invalidade de uma delas através da aplicação de critérios como "lex superior derogat legi inferiori, lex posterior derogat legi priori e lex specialis derogat legi generali”. Tal resolução de conflitos entre regras é possível tendo em vista que as regras prescrevem imperativamente uma exigência definitiva. Desse modo, havendo o conflito, procede-se a um juízo de invalidez - que implica a necessária exclusão de uma delas do sistema.

No caso dos princípios, quando entram em colisão, como ocorre quando um permite algo que é proibido por outro, um deles deve ceder - o que não significa a declaração de invalidez daquele rechaçado, nem mesmo que se lhe deva introduzir uma cláusula de exceção. Ocorre que, em determinadas circunstâncias, um princípio é preferido a outro, mas em caso concreto diverso, a precedência pode ser estabelecida de maneira inversa. De fato, sucede que, no caso concreto, sob certas circunstâncias, os princípios têm peso diferente, devendo ser aplicado o princípio de maior peso. Ou seja, o conflito de regras é resolvido na dimensão de validade, enquanto o de princípios na dimensão do peso, já que somente colidem princípios válidos, e a preferência por um, como já se disse, não significa a declaração de invalidez do(s) outro(s). Requer-se, portanto, segundo a teoria de Alexy, para a solução de uma colisão de princípios, o sopesamento de bens jurídicos, sob as circunstâncias do caso concreto, que estabelecerá uma relação de precedência condicionada.

Decorre do exposto até aqui o caráter prima facie dos princípios, uma vez que não são mandatos definitivos, mas de otimização, que ordenam que algo deva ser realizado na maior medida possível segundo as circunstâncias jurídicas e fáticas de um caso específico. Não se propõem, assim, resultados definitivos de sua aplicação, vez que podem ser afastados em condições inversas, por razões opostas. Por outro lado, as regras são mandatos definitivos, que exigem que se faça exatamente o estabelecido nelas, ressalvado o caso de introdução de uma exceção fundamentada em um princípio. Afastada a determinação da regra, pode-se ter como resultado a sua invalidade. Ou seja: “os princípios 
são sempre razões prima facie; as regras, a menos que se tenha estabelecido uma exceção, razões definitivas" ${ }^{, 200}$.

\subsection{A aplicação da regra da proporcionalidade.}

A solução de colisões de normas de direitos fundamentais no campo das regras se dá através da aplicação dos tradicionais critérios de solução de antinomias jurídicas. No entanto, no âmbito principiológico, a colisão de valores colidentes conduz à necessidade de ponderação. Isso porque no campo dos princípios a colisão não significa que se deva declarar um dos princípios inválidos, mas tão somente que através de um exercício de ponderação dos valores congregados contrapostos, há que se estabelecer uma relação de precedência condicionada, que determina qual dos valores possui maior peso naquela circunstância determinada.

Partindo-se das idéias de Alexy, a solução para a colisão de normas de direitos fundamentais é o exercício da ponderação, com aplicação da máxima da proporcionalidade. $\mathrm{O}$ mandato de ponderação pressupõe a legitimidade dos meios empregados e dos fins perseguidos com a restrição de um direito fundamental, bem como a adequação desses meios para a consecução dos objetivos pretendidos e a necessidade de sua utilização, uma vez que "os princípios são mandatos de otimização com relação às possibilidades jurídicas",201.

Estabelece-se, então, a divisão da regra de proporcionalidade em três subregras: adequação, necessidade e proporcionalidade em sentido estrito, as quais são aplicadas segundo uma ordem de precedência. Ou seja, o exercício de análise da adequação precede o da necessidade, que, por sua vez, tem precedência sobre o da proporcionalidade em sentido estrito. Desse modo, a aplicação da regra da proporcionalidade em sentido estrito tem caráter subsidiário, ocorrendo somente nos casos de um ato estatal restritivo de direitos fundamentais ser considerado adequado e necessário. Nas palavras de Boulos (2002, p. 192):

\footnotetext{
${ }^{200}$ ALEXY, 1993, p.101.

${ }^{201}$ Idem, ibidem, p. 112.
} 
Esse diferente peso que se atribui aos testes de adequação e necessidade decorre, em verdade do processo decisório envolvido sob a ótica da proporcionalidade em sentido amplo. Suas três componentes - adequação, necessidade e proporcionalidade em sentido estrito - estruturam-se em círculos concêntricos: o teste que se poderia dizer mais 'ameno', a adequação, ocupa a posição central, e o mais rigoroso, a proporcionalidade em sentido estrito, a posição que contém as demais. Dessa forma, pode uma medida restritiva de direito ser adequada à finalidade que se quer atingir, mas não necessariamente seria necessária e proporcional. A medida considerada necessária, obrigatoriamente será adequada, mas não necessariamente proporcional. Por fim, quando se chega à conclusão de que uma medida atende ao requisito da proporcionalidade em sentido estrito, então, obrigatoriamente será adequada e necessária. A decisão sobre a proporcionalidade de uma medida restritiva passa, assim, por três etapas: adequação, necessidade e proporcionalidade em sentido estrito, nessa ordem, a passagem pela anterior sendo "pré-requisito" para a análise da medida sob a ótica seguinte.

As três sub-regras da regra maior de proporcionalidade são, de fato, dedutíveis da natureza principiológica das normas de direitos fundamentais. Nas palavras de Alexy (1993, p. 111/112):

[...] Que o caráter de princípio implica a máxima da proporcionalidade significa que a proporcionalidade, com suas três máximas parciais da adequação, necessidade (postulado do meio mais benéfico) e da proporcionalidade em sentido estrito (o postulado da ponderação propriamente dito) é inferida logicamente do caráter de principio, é dizer, é deduzivel dele ${ }^{202}$.

A primeira das regras exige que o meio aplicado seja adequado, em outras palavras, "apto para alcançar o resultado pretendido" 203 ou a fomentar a realização do objetivo almejado. Destarte, "uma medida somente pode ser considerada inadequada se sua

${ }^{202}$ Tradução livre de: “[...] Que el carácter de principio implica la máxima de proporcionalidad significa que la máxima de la proporcionalidad, com sus tres máximas parciales de la adequación, necessidad (postulado del medio más benigno) y de la proporcionalidad en sentido estricto (el postulado de ponderación propriamente dicho) se infiere lógicamente del carácter de principio, es dicir, es deducible de él".

${ }^{203} C f$. ÁVILA, Humberto Bergmann. "A distinção entre princípios e regras e a redefinição do dever de proporcionalidade", Revista Diálogo Jurídico, Salvador, CAJ - Centro de Atualização Jurídica, v. I, n. ${ }^{\circ}$ 4, julho, 2001, p. 30 
utilização não contribuir em nada para fomentar a realização do objetivo pretendido"204 . A limitação será, ainda, necessária caso a realização do fim pretendido não se possa dar por outro meio senão aquele adotado. Igualmente, a análise deve considerar a intensidade da realização do objetivo perseguido e da limitação conseqüente. Ou seja, para ser necessária a restrição proposta, não pode ser possível a promoção do objetivo pretendido, com a mesma intensidade, por outro meio que em menor intensidade limite o direito fundamental atingido $^{205}$. Tem-se assim que, ao contrário do exame de adequação, o de necessidade pressupõe um exame comparativo entre duas medidas apresentadas, de modo que se determine qual delas fomenta o objetivo proposto em maior intensidade, e restringe o direito fundamental colidente em menor intensidade. Cite-se elucidativo esquema apresentado por Virgílio Afonso da Silva:

Suponha-se que para promover o objetivo O, o Estado adote a medida M1, que limita o direito fundamental D. Se houver uma medida M2, que, tanto quanto M1, seja adequada para promover com igual eficiência o objetivo $\mathrm{O}$, mas limite o direito fundamental D em menor intensidade, então a medida M1, utilizada pelo Estado, não é necessária. ${ }^{206}$

Após considerada adequada e necessária a restrição a um direito fundamental, parte-se ao exame da proporcionalidade em sentido estrito, que consiste no sopesamento racional entre a importância da realização do direito fundamental considerado precedente com a restrição do direito fundamental com este colidente. ${ }^{207}$ Tal sopesamento fundamenta a restrição do direito atingido. Assim, para que uma medida não seja

204 AFONSO DA SILVA, Virgílio. “O proporcional e o razoável”, Revista dos Tribunais, no 798, 2002, p.37.

${ }^{205}$ Nesse sentido, Gavara de Cara informa que "el Tribunal Constitucional alemán há estabelecido que uma medida es necesaria cuando no puede ser elegida otra medida igualmente efectiva que limite menos el derecho fundamental o que suponga uma menor carhga para el titular". GAVARA DE CARA, Juan Carlos. Derechos fundamentales y desarrollo legislativo: la garantía del contenido esencial de los derechos fundamentales em la Ley Fundamental de Bonn. Madrid: Centro de Estudios Constitucionales, 1994, p. 305.

206 AFONSO DA SILVA, V. (2002, p. 38).

207 Afirma Canotilho: "Quando se chegar à conclusão da necessidade e adequação da medida coactiva do poder público para alcançar determinado fim, mesmo neste caso deve perguntar-se se o resultado obtido com a intervenção é proporcional à 'carga coactiva' da mesma. Está aqui em causa o princípio da proporcionalidade em sentido estrito, entendido como princípio da 'justa medida'. Meios e fins são colocados em equação mediante um juízo de ponderação, com o objectivo de se avaliar se o meio utilizado é ou não desproporcionado em relação ao fim. Trata-se, pois, de uma questão de 'medida' ou 'desmedida' para se alcançar um fim: pesar as desvantagens dos meios em relação às vantagens dos fins". CANOTILHO, José Joaquim Gomes. Direito constitucional e teoria da constituição. 6 ed. Coimbra: Almedina, 1993, p. 219. 
proporcional em sentido estrito é necessário que a importância da adoção desta não tenha peso suficiente para justificar a restrição de um direito igualmente fundamental ou até mesmo a não aplicação do núcleo essencial deste ${ }^{208}$. Diversamente, a aprovação nesse último teste significa que a restrição é adequada, necessária e proporcional em sentido estrito, justificando-se - no caso concreto determinado - que o direito fundamental, que representava um princípio prima facie, colidido, tenha seu núcleo essencial restringido.

\subsection{Breves conclusões sobre o principialismo. A teoria do discurso}

\section{aplicada à bioética.}

A exposição do paradigma principialista da bioética, ora revisitado em conexão com a teoria do discurso, teve por objetivo destacar a importância do estabelecimento de um procedimento argumentativo decisório que seja capaz de tornar coerentes e não arbitrárias as decisões tomadas pelo judiciário e comitês de ética no que atine às questões suscitadas pelos avanços da ciência e da biotecnologia, o que engloba as técnicas de engenharia genética, a fim de garantir a proteção dos direitos humanos e da dignidade da pessoa humana.

É certo que uma decisão deriva, em grande medida, da sensação do indivíduo do que considera certo e errado, de um sexto sentido, que acaba por valorar os fatos e motivar o seu convencimento. Atienza (2002, p. 25) pondera ser possível que as decisões sejam tomadas, ao menos em parte, de modo irracional, para depois subemeterem-

${ }^{208}$ Nesse sentido, cumpre mencionar a enunciação de Medina Guerreiro ao proceder à análise da jurisprudência do Tribunal Constitucional espanhol, especialmente no tocante à STC 62/1982, fundamento jurídico $5^{\circ}$ : "o princípio da proporcionalidade não se traduz, em última análise, senão em máxima de que se deve buscar lograr um equilíbrio entre as vantagens e prejuízos que inevitavelmente se geram quando se limita um direito a fim de proteger outro direito ou bem constitucionalmente protegido. Deve, em suma, proceder-se a uma valoração confrontada dos interesses particulares e coletivos contrapostos, o que exige a consideração de todas as circunstâncias relevantes do caso concreto." Tradução livre de: " el principio de proporcionalidad en sentido estricto no se traduce, a fin de cuentas, sino en la maxima de que deve tenderse a lograr un equilibrio entre las ventajas y perjuicios que inevitablemente se generan cuando se limita un derecho a fin de proteger outro derecho o bien constitucionalmente protegido. Debe, en suma, procederse a una valoración confrontada de los intereses particulares y colectivos contrapuestos, lo que exige tomar en consideración todas las circunstancias relevantes del caso concreto". MEDINA GUERREIRO, Manuel. La vinculación negativa del legislador a los derechos fundamentales. Madrid: McGraw-Hill, 1996, p. 132. 
se a uma forma racional, em um processo que vai da conclusão às premissas ${ }^{209}$. Ou seja, uma decisão é resultado de uma valoração subjetiva - ainda que inconsciente - dos fatos concretos considerados e da norma: moral ou jurídica. Não é, possível, portanto, obter-se uma decisão completamente livre de subjetividade, pois o próprio ato de interpretação da norma e de compreensão dos fatos comporta uma valoração antecipada, que é psicologicamente e sociologicamente determinada.

Destarte, considerando-se que a decisão pode derivar de um processo intelectivo que inicialmente processa-se de forma irracional, e depois vai da conclusão à análise das premissas, na busca dos seus fundamentos, permanece a aplicação da regra da proporcionalidade, enquanto instrumental da teoria do discurso, ocupando posição central.

Cohen e Segre (2002, p. 56), ressaltam que "ser ético é poder percorrer o caminho entre a emoção e a razão, permitindo-nos que nos posicionemos na parte deste percurso que consideremos mais adequada”, conforme já se destacou. Diante de tal noção da ética, a aplicação das sub-regras da adequação, necessidade e proporcionalidade em sentido estrito funcionam como um check list que pode permitir aos comitês de ética e ao judiciário precisar se as suas decisões - nos casos de colisão de princípios - baseiam-se em critérios racionais, e, assim, garantir a fundamentação clara e objetiva que deve acompanhar o processo decisório que visa a maximizar a efetivação dos direitos humanos e da dignidade da pessoa humana.

\section{A aplicacão da teoria do discurso na solucão dos dilemas de bioética} suscitados pelas técnicas de engenharia genética. A contribuição de Manuel Atienza.

Atienza, em sua obra Bioética, derecho y argumentación ${ }^{210}$, no mesmo sentido dos autores alemães Habermas e Alexy, abordados nesse trabalho, propõe a utilização da teoria do discurso como proposta metodológica a ser aplicada na busca de

\footnotetext{
${ }^{209}$ E completa: "As decisões decorrem não de um processo racional de formação da convicção, mas defluem de posições subjetivas, fruto da experiência individual do julgador e de seus preconceitos de ordem política, econômica, social”. ATIENZA, 2002, p. 25.

${ }^{210}$ ATIENZA, Manuel. Bioética, derecho y argumentación. Lima-Bogotá: Temis, 2004.
} 
soluções para os conflitos gerados pelo avanço da ciência e da biotecnologia nos dias atuais. Estabelece, então, uma estreita relação entre a bioética e o direito, de cunho metodológico e procedimental. Ele propõe, assim como Alexy, a ponderação de princípios contrapostos como meio necessário à solução de conflitos emergentes, afirmando, ademais, que a ferramenta hermenêutica desenvolvida pelo direito é de relevante utilidade para a aplicação dos princípios da bioética. Nas palavras de Barreto, “Atienza propõe um método de ponderação, a ser utilizado pelos juízes, sem receio de socorrer-se aos recursos da

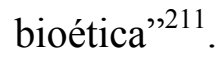

Atienza (2004, p. 11), parte, portanto, da premissa de que "os problemas da bioética são essencialmente problemas de argumentação" ${ }^{212}$, que devem ser solucionados segundo critérios de racionalidade prática $^{213}$. Ou seja, como bem expõe o autor espanol ${ }^{214}$, a idéia de fundo é a de que o método jurídico da ponderação de princípios (que supõe o estabelecimento de regras de prioridade), muito utilizado pelos tribunais espanhóis e alemães para a resolução de casos de colisão de direitos fundamentais, poderia ser aplicado pelos comitês de bioética - procedimento que, inclusive, sugerimos seja adotado no Brasil - a fim de que, reitere-se, o processo decisório tenha por fundamento razões que podem ser amplamente aceitas em uma sociedade pluralista. Nesse sentido, anota Atienza (2004, p. 119) que "as razões que mutuamente damo-nos no discurso público devem poder serem compreendidas e eventualmente aceitas por todos os outros, é dizer, por qualquer que participe do debate como cidadão livre e igual aos demais" ${ }^{215}$.

É certo, ademais, que a discussão sobre questões bioéticas, com base na argumentação, pode ocorrer em diferentes contextos, o que inclui, tanto o âmbito do

\footnotetext{
${ }^{211}$ BARRETO, Vicente de Paulo. O vaso de pandora da biotecnologia: impasses éticos e jurídicos. In: Heleno Taveira Tôrres (coord.). Direito e poder nas instituições e nos valores do público e do privado contemporâneos. Estudos em homenagem a Nelson Saldanha. 1a ed. Tamboré: Manole, 2006, p. 681.

${ }^{212}$ Tradução livre de: "los problemas de la bioetica son esencialmente problemas de argumentación".

213 ATIENZA, 2004, p. 11.

${ }^{214}$ Idem, ibidem, p. 11.

215 Tradução livre de: "las razones que mutamente nos damos en el discurso público tienen que poder ser comprendidas y, eventualmente, aceptadas por todos los otros, es decir, por cualquiera que participe en el debate como ciudadano libre e igual a los demás”.
} 
direito $^{216}$ como o dos comitês de ética médica, e que às duas instâncias de solução dos conflitos no âmbito da bioética são aplicáveis o método de ponderação de princípios como modelo plausível de racionalidade prática. Dessarte, o que se necessita no âmbito da bioética é, sobretudo, de "um método de discussão, um procedimento que nos permita chegar a acordos razoáveis através de um intercâmbio de razões capaz de eliminar as más razões e as que parecem boas mas não são" ${ }^{217}$. E, não obstante os comitês de ética ${ }^{218}$ não possam emitir, em certos casos, decisões vinculantes, seus julgamentos são relevantes como orientação para os profissionais da área da saúde ${ }^{219}$. Nas palavras de Atienza (2004, p. 77): “os membros desses comitês estão, em efeito, em uma situação análoga à dos juízes que têm que resolver casos jurídicos baseando-se essencialmente em princípios "220.

\footnotetext{
${ }^{216}$ Nesse sentido, Atienza (2004, p. 77) anota que outrossim o judiciário deve estar preparado para solucionar os conflitos trazidos pela bioética e, dessa forma, para o referido autor, os juristas devem ter uma participação maior do que têm atualmente.

217 Tradução livre de: "un método de discusión, un procedimiento que nos permita llegar a acuerdos razonables a través de un intercambio de razones capaz de eliminar las malas razones y las que parecen buenas pero no lo son". (ATIENZA, 2004, p. 13).

${ }^{218}$ Para Atienza (2004, p. 40), a existência de Comitês de ética médica é justificada por duas razões principais: "Una de ellas es servir de apoyo - pero no sustitir: la conciencia ética es algo de cada cual - al profesional, a los familiares o al enfermo quue haya de tomar una decisión en um contexto de conflicto ético. La outra es ejercer un control social en un ámbito en que están en juego derechos e intereses de todos y cada uno de los individuosde una comunidad".

${ }^{219}$ Idem, ibidem, p. 27.

${ }^{220}$ Tradução livre de: "los miembros de esos comités están, en efecto, en una situación análoga a la de los jueces que tienen que resolver casos jurídicos basándose esencialmente en principios".
} 


\section{CAPÍTULO IV - O DIREITO E A PROTECC̃̃O DA DIGNIDADE HUMANA E DOS DIREITOS HUMANOS NA ERA DA GENÉTICA}

\section{Positivacão de direitos humanos na ordem internacional.}

A partir do século $\mathrm{XX}$, o processo de formulação positiva dos direitos fundamentais ultrapassou o âmbito interno dos Estados para consolidar-se como uma exigência transnacional. Os acontecimentos políticos conduziram a que a sua positivação, antes restrita ao direito interno, atingisse o direito internacional, flexibilizando-se o princípio da soberania estatal, a fim de que pudessem ser controladas as violações aos direitos humanos cometidas pelos Estados. É de se ver, por outro lado, que o processo de positivação de tais direitos, também no plano internacional, é fruto de aspirações políticas, filosóficas e ideológicas, historicamente determinadas. Destarte, não se deve dissociá-lo da busca do homem contemporâneo pela afirmação dos princípios da dignidade da pessoa humana, da liberdade e igualdade, que se revestem do conteúdo determinado pelos valores preponderantes na comunidade internacional atual. Neste tocante, as considerações finais de Pérez-Luño (1984, p. 131) acerca do processo de positivação dos direitos fundamentais merecem ser transcritas:

Pretender separar o processo de positivação dos directos fundamentais do longo e trabalhoso esforço dos homens na luta pela afirmação de sua dignidade, liberdade e igualdade, como princípios básicos da convivência política, é como privar esse processo de seu significado. A própria sede habitual de positivação jurídica de tais directos fundamentais, que não é outra que a dos princípios retores do ordenamento constitucional, revela a constante tensão dialética entre o plano ideológico [...] das aspirações políticas e o técnico no terreno da positivação das normas jurídicas ${ }^{221}$.

\footnotetext{
221 Tradução livre de: "Pretender desgajar el proceso de positivación de los derechos humanos fundamentales del largo y laborioso esfuerzo de los hombres en la lucha por la afirmación de su dignidad, libertad e igualdad, como principios básicos de la convivencia política, es tanto como privar a dicho proceso de su significado. La propria sede habitual de positivación jurídica de tales derechos fundamentales, que nos es otra que la dos principios rectores del orden constitucional, revela la constante tensión dialéctica entre el plano ideológico [...] de las aspiraciones políticas, y el técnico en el terreno de la positividad de las normas juridicas". (PÉREZ-LUÑO, 1984, p. 131).
} 
O desenvolvimento dos direitos humanos tornou claro que sua proteção não se esgota na atuação interna estatal. A competência nacional exclusiva pode ser definida como uma manifestação inadequada da soberania no contexto pós-moderno, em que emergem dilemas éticos e situações de risco de caráter global. Não é possível, portanto, sustentar, atualmente, a tese do domínio reservado do Estado em matéria de direitos humanos e bioética ${ }^{222}$. É neste cenário que a proteção internacional dos direitos humanos suscita a indagação acerca da força vinculante dos documentos que prevêem tais direitos.

Para analisar tal questão, partimos da noção de que a vigência dos direito humanos independe de sua declaração em constituições, leis e tratados internacionais, pois consagradores do conteúdo valorativo da dignidade humana. A partir de tal premissa, destacamos que tal questionamento aborda o tema das fontes do direito internacional, sobre as quais se deve discorrer preliminarmente.

Fontes do direito internacional são meios através dos quais o direito se manifesta. Possuem força vinculante e estão definidas no art. 38 do Estatuto da Corte Internacional de Justiça:

Art. 38 .

I - A corte, cuja função é decidir de acordo com o Direito Internacional as controvérsias que lhe forem submetidas, aplicará:

a) as convenções internacionais, quer gerais, quer especiais, que estabeleçam regras expressamente reconhecidas pelos Estados litigantes.

b) o costume internacional, como prova de uma prática geral aceita como sendo direito;

c) os princípios gerais de direito reconhecidos pelas Nações civilizadas;

d) sob reserva da disposição do art. 59, as decisões judiciárias e a doutrina dos publicistas mais qualificados das diferentes nações, como meio auxiliar para a determinação das regras de direito.

\footnotetext{
${ }^{222}$ Neste sentido, transcrevemos os comentários de Cançado Trindade (1998, p. 03/04): “um reflexo, uma manifestação ou particularização da própria noção de soberania, inteiramente inadequada ao plano das relações internacionais, porquanto originalmente concebida, tendo em mente o Estado 'in abstracto' (e não suas relações com outros Estados), e como expressão de um poder interno, de uma supremacia própria de um ordenamento de subordinação, claramente distinto do ordenamento internacional, de coordenação e cooperação, em que todos os Estados são, ademais de independentes, juridicamente iguais. Nos dias de hoje, não há como sustentar que a proteção dos direitos humanos recairia sob o chamado 'domínio reservado do Estado', como pretendiam certos círculos há cerca de três ou quatro décadas atrás".
} 
Vê-se, desde logo, que convenções e tratados internacionais possuem força vinculante, pois podem ser considerados instrumentos legislativos firmados no âmbito da ordem internacional. Como bem afirma Monaco, tais documentos "não apenas recomendam que os Estados respeitem e promovam os direitos humanos declarados (caso das declarações de direitos), como instituem uma série de obrigações jurídicas no sentido do respeito àqueles mesmos direitos, a seus desenvolvimentos conceituais ou a seus desdobramentos $[\ldots]^{, 223}$.

Entretanto, além dos tratados e pactos em vigor, o costume e os princípios gerais de direito reconhecidos pelas nações civilizadas constituem fontes do direito internacional, possuindo, portanto, força vinculante. Com efeito, ainda que se possa afirmar que a Declaração Universal de Direitos Humanos de 1948 não seja um tratado, tendo em vista que foi adotada pela Assembléia Geral da ONU sob a forma de uma resolução, não restam dúvidas de que constitui direito costumeiro, fonte do direito internacional - o que lhe garante força vinculante. Piovesan destaca, nesse sentido, as palavras proferidas por Roosevelt na data em que foi aprovada a Declaração Universal dos Direitos Humanos:

ao aprovar esta Declaração hoje, é de primeira importância ter a clareza das características básicas deste documento. Ele não é um tratado; ele não é um acordo internacional. Ele não é e não pretende ser um instrumento legal que contenha obrigação legal. É uma declaração de princípios básicos de direitos humanos e liberdades, que será selada com aprovação dos povos de todas as nações ${ }^{224}$.

A noção de que a Declaração Universal dos Direitos Humanos integra o direito costumeiro internacional, apresentando, assim, força vinculante, parte da constatação de que, desde sua proclamação, ela tem sido invocada por inúmeros Estados, e também pela Assembléia Geral da ONU, para justificar algumas posições adotadas no âmbito internacional. Além disso, é de se considerar que diversas constituiçõos nacionais consagraram o conteúdo da Declaração Universal, incorporando-o ao direito interno -,

\footnotetext{
${ }^{223}$ MONACO, 2006, p. 75/76.

${ }^{224}$ PIOVESAN, Flávia. Direitos Humanos e o direito constitucional internacional. São Paulo: Max Limonad, 1996, p. 155.
} 
transformando-o, de fato, em direito costumeiro vinculante. Nesse ponto, registramos, mais uma vez, por oportuno, as palavras de Flávia Piovesan:

[...] ainda que a Declaração Universal de 1948 não assuma a forma de tratado internacional, apresenta força jurídica obrigatória e vinculante - o que se reforça pelo fato de, na qualidade de um dos mais influentes instrumentos jurídicos e políticos do século XX, ter se transformado, ao longo dos mais de cinquenta anos de sua adoção, em direito costumeiro internacional e princípio geral do direito internacional ${ }^{225}$.

Dessarte, tendo em vista a teoria das fontes do direito internacional - que considera o costume internacional e os princípios gerais de direito reconhecidos pelas nações civilizadas como fontes de direitos vinculantes, resta claro que se admite, no plano internacional, direitos humanos não previstos em tratados ou pactos em vigor, como ocorre com aqueles definidos na Declaração Universal dos Direitos Humanos de 1948, porquanto a ampla aceitação das nações transformou-os em direito costumeiro vinculante, aplicável a todos os Estados e não apenas aos signatários da referida Declaração. Quanto ao costume internacional ${ }^{226}$, ressaltamos que ele se forma através de reiteradas práticas e usos dos Estados e que somente após a formação de tal elemento material ele se transforma em norma de direito internacional, pois “à prática se soma o elemento psicológico de ser tidos como direito",227.

Todavia, alguns direitos humanos proclamados em âmbito internacional não estão previstos em tratados ou pactos em vigor e também não podem ser, ainda, considerados como um direito consuetudinário amplamente aceito e consagrado pelas nações civilizadas. Diante de tal constatação, a força vinculante dos documentos que os consagra é, segundo entendimento de muitos, diminuída, fazendo com que sejam considerados soft law em relação ao ordenamento jurídico brasileiro. Discordamos,

\footnotetext{
${ }^{225}$ PIOVESAN, 1996, p. 160.

${ }^{226}$ Importante destacar que "o fator temporal também pouco influencia a formação do costume. Se é verdade que em passado não muito remoto o costume demorava alguns séculos para cristalizar-se, também é verdade que os avanços tecnológicos e de comunicação, que implicam a diminuição das distâncias e a rápida troca de informações, acabaram por tornar mais acelerada a transformação de um simples uso em algo jurídico, dotado de sociabilidade, imperatividade e coercitividade como é que se verifica relativamente ao costume". (MONACO, 2006, p. 58).

${ }^{227}$ Idem, ibidem, p. 70.
} 
contudo, deste entendimento, ao argumento de que a Constituição de 1988 reconhece a prevalência dos direitos humanos como princípio fundamental a reger o Brasil nas relações internacionais, nos termos do seu artigo $4^{\circ}$, inciso II.

Ademais, cumpre reiterar a íntima vinculação entre o princípio da dignidade da pessoa humana e os direitos fundamentais. Pérez Luño afirma que a dignidade da pessoa humana constitui não apenas a garantia negativa de que a pessoa não será objeto de ofensas ou humilhações, mas implica também, num sentido positivo, o pleno desenvolvimento da personalidade de cada indivíduo - sendo possível, portanto, descrever-se outros direitos humanos derivados de tal dignidade, que possui um núcleo essencial que deve ser sempre respeitado.

Considerando-se, então, que no ordenamento jurídico brasileiro a noção de dignidade da pessoa humana encontra-se expressamente definida no art. $1^{\mathrm{o}}$, inc. III da Constituição Federal, no qual está claramente exposta a intenção do legislador constituinte de outorgar aos princípios fundamentais a qualidade de normas embasadoras e informativas de toda a ordem constitucional: limite e tarefa dos poderes estatais, e partindo-se, igualmente, do dever de proteção da dignidade humana, conclui-se que a nossa Constituição é materialmente aberta e que direitos de caráter fundamental para a pessoa humana devem ser respeitados, ainda que não explicitamente contidos nela. Assim é que os princípios definidores de direitos fundamentais, consubstanciados na máxima da dignidade da pessoa humana, cumprem função de referencial hermenêutico, uma vez que atuam como fundamento para a eventual dedução de direitos não-escritos. Ou seja, servem de norte obrigatório para o reconhecimento da fundamentalidade material dos direitos garimpados fora do catálogo constitucional.

É certo que a inserção constitucional desses direitos na Constituição brasileira confere-lhes rigidez e supremacia, de sorte que não podem ser desfigurados ou modificados pelo processo legislativo ordinário. Todavia, a eventual ausência de previsão constitucional de certos direitos humano, como ocorre com o direito à proteção do patrimônio genético, não faz com que eles deixem de existir ou que não devam ser protegidos, visto que o dever de proteção ao núcleo essencial do princípio da dignidade da 
pessoa humana, previsto no artigo $1^{\circ}$, inciso III, da Constituição Federal, impõe a obrigação de proteção, na máxima medida possível, de todos aqueles direitos, que, ainda que não reconhecidos constitucionalmente, contribuam para o amplo desenvolvimento da personalidade humana.

\section{Declaraç̃o Universal sobre Bioética e Direitos Humanos}

\subsection{Apresentação. Aspectos gerais da Declaração Universal sobre}

\section{$\underline{\text { Bioética e Direitos Humanos }}$}

Em 19 de outubro de 2005, a $33^{\mathrm{a}}$ Conferência Geral da UNESCO (Organização das Nações Unidas para a Educação, a Ciência e a Cultura) aprovou por unanimidade a Declaração Universal sobre Bioética e Direitos Humanos - que possui como principal objetivo constituir um marco inspirador de políticas, legislações e códigos éticos para os 191 países-membros da ONU, especialmente tendo em vista que apenas 50 dessas nações possuem um comitê nacional de bioética. Ressaltamos que o apoio concedido à aprovação unânime da Declaração decorreu de um motivo principal: o fato de que ela não abordou pontos considerados mais polêmicos, como clonagem, eutanásia e pesquisas com embriões.

A Declaração foi redigida pelo Comitê Internacional de Bioética da UNESCO, única instância existente no campo da bioética em nível internacional, criado em 1993, e composto por 36 experts independentes que analisam as conseqüências éticas do progresso das ciências no âmbito de proteção dos princípios da dignidade e da liberdade da pessoa humana $^{228}$. Constituiu o primeiro texto generalista de bioética proclamado em nível

\footnotetext{
${ }^{228}$ Importante destacar que a criação do Comitê Internacional de Bioética da Unesco foi impulsionada pela ampla divulgação de que pesquisadores estadunidenses, que estudavam a transmissão vertical do HIV, usavam um grupo de controle com placebo na África, onde não exitiam Comitês de ética em pesquisa e a legislação era mais branda: "Such research would not been allowed in the USA where effective but costly
} 
internacional e certamente consistirá em um instrumento importante de atração de atenções para temas a ela correlatos. Insere-se no contexto de proclamação de documentos relacionados com o desenvolvimento científico e tecnológico alcançado na atualidade, que buscam consolidar as noções de solidariedade e justiça social. Foi precedido pela Declaração Universal sobre o Genoma Humano e os Direitos Humanos (1997) e pela Declaração Internacional sobre os Dados Genéticos Hhumanos, as quais abordaremos em seguida.

O conteúdo da Declaração é muito semelhante ao do "Convênio de Oviedo" - transformado em Convenção dos Direitos do Homem e da Biomedicina do Conselho da Europa. Todavia, ainda que o alcance do documento aprovado pela Unesco seja muito maior, o Convênio é, sem qualquer discussão, juridicamente vinculante para as partes que o subscrevem - o que não ocorre com uma Declaração ${ }^{229}$, embora acreditemos em sua força vinculante decorrente do dever de proteção dos direitos humanos e da dignidade da pessoa humana. Emerge, então, a dúvida quanto à eficácia dos enunciados do documento em comento, fazendo-nos crer que normas deverão ser editadas pelos países no tocante aos temas de bioética.

De qualquer modo, a Unesco pretende garantir ao texto desta Declaração ampla aplicação, através do fortalecimento e implementação de outros programas relacionados à bioética, dentre os quais anuncia a instalação do observatório mundial de ética e a criação de um programa de ajuda para os comitês de bioética - que contarão com a publicação de guias-práticos para sua orientação ${ }^{230}$. Nesse sentido, é de se destacar que, ainda que Declaração, ora em análise, expresse o reconhecimento ao pluralismo e à diversidade cultural, busca estabelecer princípios éticos que considera como sendo universalmente aplicáveis - propondo, portanto, uma interpretação universalista dos direitos humanos.

therapy is available." LURIE P. e WOLFE, S.M. Unethical trials of interventions to reduce perinatal transmission of the immunodeficiency virus in developing countries. N. Eng.: Med. N. 337, 1997, p. 853/856.

${ }^{229}$ Vide Editorial da Revista de Bioética e Derecho, número 06, marzo de 2006, p. 01.

${ }^{230}$ Idem, ibidem, p. 02. 
Inicialmente, fora proposto o título de "Declaração de Normas Universais de Bioética" - que visava a garantir uma natureza vinculante retórica à ela. Contudo, o dissenso manifestado no tocante a certos temas mais polêmicos - como, por exemplo, a questão da eventual proteção a ser concedida aos embriões humanos - fez com que a Declaração se restringisse à enunciação de princípios gerais e houvesse a supressão do termo "normas" do seu título. A palavra "universal", a seu turno, não se refere unicamente à aplicação geral dos princípios enunciados por ela, mas também enfatiza a noção de reconhecimento de princípios globais de bioética.

De fato, a Declaração propõe princípios que consideram as dimensões sociais, jurídicas e ambientais de questões relacionadas com a medicina e tecnologias, construindo-se, assim, uma moldura ética para sua aplicação a seres humanos. Busca fomentar a solidariedade e a responsabilidade social, a fim de que os países em desenvolvimento também possam participar do progresso científico e da tecnologia - que devem produzir maior justiça e eqüidade. Nesse sentido, sublinhamos as palavras de Koïchiro Matsuura, diretor geral da Unesco, proferidas em sessão extraordinária do Comitê Internacional de Bioética:

Acredito que a comunidade internacional acolherá estas propostas com interesse, pois elas evidenciam, no quadro de uma reflexão normativa referente à proteção dos direitos humanos, a forte ligação que une o debate ético e a preocupação com o bem-estar das gerações futuras" e evoca "com maior precisão os questionamentos relativos ao acesso aos tratamentos de saúde com qualidade, à nutrição e à qualidade da água adequadas, à redução da pobreza ou ao melhoramento das condições ambientais, abrindo, desse modo perspectivas de ação que vão além da simples ética médica e reiterando a necessidade de inscrever a bioética no contexto de uma reflexão aberta sobre o mundo político e social.

\subsection{O preâmbulo}

O preâmbulo da Declaração afirma "ser necessário e oportuno que a comunidade internacional declare princípios universais que proporcionarão uma base para a 
resposta da humanidade aos sempre crescentes dilemas e controvérsias que a ciência e a tecnologia apresentam à espécie humana e ao meio ambiente"231, os quais devem, ademais, serem anunciados com o devido respeito à dignidade da pessoa humana. Recorda, em seguida, alguns documentos definidores de direitos humanos proclamados em âmbito internacional - sejam eles juridicamente vinculantes ou não, restando claro que a Declaração de Bioética deve ser interpretada em conformidade com as disposições constantes neles. Da análise do contexto hermenêutico proposto pela Unesco para os princípios de bioética ora proclamados, concluímos que se inserem em um cenário ético ocidental que omite, por exemplo, a Declaração islâmica Universal de Direitos Humanos.

Acrescentamos, ademais, que dentre os instrumentos definidos como premissas para a Declaração de bioética, três merecem destaque: a Declaração de Helsinque, a Convenção de Direitos Humanos e Biomedicina do Conselho da Europa e as Diretrizes Éticas Internacionais para Pesquisas Biomédicas Envolvendo Seres Humanos, do Conselho para Organizações Internacionais de Ciências Médicas - CIOMS - já que a referência a instrumentos adotados fora do sistema das Nações Unidas consiste em uma novidade para a tradição legal da Unesco. No que tange às agências especializadas, a Organização para a Alimentação e a Agricultura da Organização das Nações Unidas (FAO) e a Organização Mundial da Saúde (OMS) são especialmente mencionadas como sendo instituições que têm adotado instrumentos relevantes para a bioética.

O conteúdo ético proclamado divide-se em princípios que incluem a tradição ética médica ocidental - que enfatiza a beneficência e não-maleficência - e a transpõem. Integram-se os princípios da autonomia, da justiça, do respeito à diversidade cultural e ao pluralismo, da solidariedade e cooperação, da responsabilidade em relação à biosfera, da não discriminação, da confidencialidade, e da obrigação de compartilhar eqüitativamente os benefícios da pesquisa. A proteção da dignidade humana e dos direitos humanos configura o fio condutor para a aplicação desses princípios, cuja garantia seria assegurada por um grupo de outros princípios - de natureza procedimental: honestidade e integridade, transparência e abertura, utilização de métodos científicos e racionais, consulta à comunidade e aos especialistas, eqüidade nos processos de tomada de decisões, necessidade

${ }^{231} \mathrm{O}$ conteúdo completo da Declaração encontra-se disponível no site da Unesco: www.unesco.org.br. 
de prevenir riscos, de construir comitês de bioética, de garantir o debate público e de levar em consideração as práticas transnacionais em geral.

\subsection{Escopo e objetivos da Declaração}

O artigo $1^{0} 232$ define o escopo da Declaração: abordar os dilemas éticos emergentes na atualidade que decorrem dos avanços da medicina e da tecnologia. Impõe uma visão multidisciplinar, que considere suas dimensões sociais, legais e ambientais. Estabelece, ainda, que a Declaração é dirigida a dois grupos de atores: o primeiro seria integrada pelos Estados e o segundo seria representado por indivíduos, comunidades, instituições, empresas públicas e privadas - aos quais a Declaração ofereceria orientação ética para suas decisões. No Relatório Explicativo divulgado pela Unesco ao primeiro rascunho dessa Declaração, afirmou-se que tal escopo refere-se aos seres-humanos, como sujeitos reconhecidos pelos princípios nela enunciados, sem prejuízo de sua responsabilidade sobre o meio-ambiente e todas as outras formas de vida presentes na biosfera. Tal entendimento parte da noção de que a ética constitui uma atividade humana, e que, portanto, somente os seres-humanos poderiam se guiar através de argumentos eticamente formulados ${ }^{233}$.

O principal objetivo da Declaração encontra-se definido no item i. do seu $\operatorname{artigo~} 2^{\text {o } 234}$ : "prover uma estrutura universal de princípios e procedimentos para orientar os

232 "Artigo 1 - Escopo

a) A Declaração trata das questões éticas relacionadas à medicina, às ciências da vida e às tecnologias associadas quando aplicadas aos seres humanos, levando em conta suas dimensões sociais, legais e ambientais.

b) A presente Declaração é dirigida aos Estados. Quando apropriado e pertinente, ela também oferece orientação para decisões ou práticas de indivíduos, grupos, comunidades, instituições e empresas públicas e privadas".

${ }^{233} \mathrm{Cf}$. Explanatory Memorandum on the elaboration of the preliminary draft Declaration on Universal Norms on Bioethics, disponível no site da Unesco: www.unesco.org.br.

234 "Artigo 2 - Objetivos

Os objetivos desta Declaração são:

i. prover uma estrutura universal de princípios e procedimentos para orientar os Estados na formulação de sua legislação, políticas ou outros instrumentos no campo da bioética;

ii. orientar as ações de indivíduos, grupos, comunidades, instituições e empresas públicas e privadas; 
Estados na formulação de sua legislação, políticas ou outros instrumentos no campo da bioética". Ademais, ela visa a orientar as ações de indivíduos, comunidades, instituições, empresas públicas e privadas, ou seja, dos sujeitos aos quais ela se dirige, conforme explicitado no artigo $1^{\circ}$. Sublinha, ainda, o respeito pela dignidade humana e pelos direitos humanos, destacando, desde já, a proeminência concedida à vida e à liberdade. Reconhece, assim, a importância da liberdade de pesquisa científica, mas define seus limites na dignidade humana, garantia dos direitos humanos e liberdades fundamentais. Estabelece, ainda, o dever de promover um diálogo plural sobre questões de bioética e de preservação dos interesses das gerações futuras, afirmando, já em seus objetivos, a relevância do princípio da solidariedade por meio da busca da promoção do acesso eqüitativo aos avanços médicos e tecnológicos, com maior atenção às necessidades dos países em desenvolvimento. Além disso, cumpre mencionar que o Relatório Explicativo divulgado pela Unesco ao primeiro rascunho dessa Declaração sublinhou, ao comentar sobre os objetivos propostos, que ela não visa a esgotar o debate bioético, porquanto, sua maior pretensão é inspirar e estimular discussões éticas em todos os Estados-membros da Organização das Nações Unidas, entendendo que a implementação do debate dos temas de bioética pode possibilitar a formação de um "consenso universal":

Nos primeiros estágios do desenvolvimento da bioética teria sido impossível alcançar consenso na maioria das questões ou em muitas delas embora com o tempo o consenso possa emergir em várias areas e em relação a

iii. promover o respeito pela dignidade humana e proteger os direitos humanos, assegurando o respeito pela vida dos seres humanos e pelas liberdades fundamentais, de forma consistente com a legislação internacional de direitos humanos;

iv. reconhecer a importância da liberdade da pesquisa científica e os benefícios resultantes dos desenvolvimentos científicos e tecnológicos, evidenciando, ao mesmo tempo, a necessidade de que tais pesquisas e desenvolvimentos ocorram conforme os princípios éticos dispostos nesta Declaração e respeitem a dignidade humana, os direitos humanos e as liberdades fundamentais;

v. promover o diálogo multidisciplinar e pluralístico sobre questões bioéticas entre todos os interessados e na sociedade como um todo;

vi. promover o acesso eqüitativo aos desenvolvimentos médicos, científicos e tecnológicos, assim como a maior difusão possível e o rápido compartilhamento de conhecimento relativo a tais desenvolvimentos e a participação nos benefícios, com particular atenção às necessidades de países em desenvolvimento;

vii. salvaguardar e promover os interesses das gerações presentes e futuras;

viii. ressaltar a importância da biodiversidade e sua conservação como uma preocupação comum da humanidade". 
diversos princípios. A formação de consensos adicionais pode ser esperado no futuro $^{235}$.

\subsection{Princípios definidos na Declaração.}

Os artigos seguintes da Declaração definem princípios que delimitam o horizonte ético proposto para a atuação de médicos e pesquisadores. Utilizou-se, repetidamente, o futuro do verbo dever: deverá ("shall"), o que demonstra, claramente, a tentativa de normatização desses princípios. Afirma-se no item 34 do Relatório Explicativo divulgado pela Unesco ao primeiro rascunho desta Declaração, que os princípios nela enunciados fundam-se na Declaração Universal de Direitos Humanos e em outros tratados de direitos humanos que a seguiram. Nesse contexto, é reconhecida a importância da escola ética hipocrática, porém anota-se que a escola da ética deontológica e consequencialista também inspiraram a declaração dos princípios propostos para a bioética.

O artigo $3^{\text {o } 236}$ define a dignidade humana, os direitos humanos e as liberdades fundamentais como princípios norteadores de toda a ação no campo da bioética, os quais, portanto, devem ser obedecidos em sua totalidade. $\mathrm{O}$ respeito pela dignidade humana deriva do reconhecimento de que todas as pessoas têm um valor incondicional, sendo capazes de determinar seu próprio destino moral. Ainda, outra faceta do alegado princípio da dignidade humana é desenhada no item b deste artigo, que estabelece que "os interesses e o bem-estar do indivíduo devem ter prioridade sobre o interesse exclusivo da ciência ou da sociedade" - acompanhando, assim, disposição já contida no art. $2^{\circ}$ da Convenção dos Direitos do Homem e da Biomedicina do Conselho da Europa. Anotamos,

\footnotetext{
${ }^{235}$ Tradução livre de: "In the early stages of the development of bioethics it would have been impossible to reach consensus on almost any issue or even many of them, whereas given time consensus may emerge in several areas and regarding several principles. Further consensus-formation can be expected in the future". Cf. Explanatory Memorandum on the elaboration of the preliminary draft Declaration on Universal Norms on Bioethics, disponível no site da Unesco: www.unesco.org.br.

236 “"Artigo 3 - Dignidade Humana e Direitos Humanos

a) A dignidade humana, os direitos humanos e as liberdades fundamentais devem ser respeitados em sua totalidade.

b) Os interesses e o bem-estar do indivíduo devem ter prioridade sobre o interesse exclusivo da ciência ou da sociedade".
} 
entretanto, que o dispositivo ora em questão desvirtua a noção de princípio ao afirmar que este deve ser respeitado "em sua totalidade", pois um mandamento de obrigação constitui uma regra e não um princípio (mandamento de otimização). Consideramos, portanto, que o artigo $3^{\circ}$, constitui de fato uma regra e não um princípio, pois, caso se lhe reconheça sua natureza principiológica, ele poderia ser relativizado quando em conflito com outros princípios, conforme se verá no capítulo $\mathrm{V}$ da segunda parte desse trabalho.

O artigo $4^{\text {o } 237}$ da Declaração trazia em sua redação original o seguinte título: "beneficência e não-maleficência" - que são princípios basilares da ética hipocrática. Todavia, o uso de termos mais neutros e modernos, como "benefício" e "dano" foi preferido, até porque o conteúdo do artigo em questão difere da máxima "primum non nocere". Consiste na afirmação de que os benefícios diretos e indiretos a pacientes e sujeitos de pesquisa devem ser maximizados e os danos minimizados. Tal formulação é muito similar a do artigo $6^{\circ}$ do Protocolo adicional à Convenção de Direitos do Homem e da Biomedicina do Conselho da Europa: “ a pesquisa não deverá envolver riscos e ônus aos seres humanos desproporcionais aos seus potenciais benefícios" 238 .

A previsão da aplicação dos princípios da autonomia e da responsabilidade individual está contida no artigo $5^{\text {o } 239}$. O respeito por tais princípios deriva diretamente da noção de dignidade humana, tendo em vista que os seres humanos não podem ser instrumentalizados e tratados como meios para fins científicos. Considera, contudo, que a autonomia comporte uma dimensão de responsabilidade pessoal em relação aos outros, que a limita em certa medida. Ou seja, garante-se a autonomia individual sem que se libere o indivíduo da responsabilidade pelos seus atos e conseqüências advindas deste.

237 "Artigo 4 - Benefício e Dano

Os benefícios diretos e indiretos a pacientes, sujeitos de pesquisa e outros indivíduos afetados devem ser maximizados e qualquer dano possível a tais indivíduos deve ser minimizado, quando se trate da aplicação e do avanço do conhecimento científico, das práticas médicas e tecnologias associadas".

${ }^{238}$ Tradução livre de: "research shall not involve risks and burdens to the human being disproportionate to its potential benefits".

239 “Artigo 5 - Autonomia e Responsabilidade Individual

Deve ser respeitada a autonomia dos indivíduos para tomar decisões, quando possam ser responsáveis por essas decisões e respeitem a autonomia dos demais. Devem ser tomadas medidas especiais para proteger direitos e interesses dos indivíduos não capazes de exercer autonomia". 
O princípio do consentimento está previsto no artigo $6^{\circ}{ }^{240}$ da Declaração e é de se observar que o item $a$ do referido artigo praticamente repete a redação do $\operatorname{artigo} 5^{\circ}$ da Convenção dos Direitos do Homem e da Biomedicina do Conselho da Europa, ao prever que "qualquer intervenção médica preventiva, diagnóstica e terapêutica só deve ser realizada com o consentimento prévio, livre e esclarecido do indivíduo envolvido, baseado em informação adequada". Sublinhamos, nesse ponto, que o consentimento informado consiste em elemento essencial da bioética contemporânea e representa desdobramento natural do princípio da autonomia, que garante a autodeterminação individual. Deve ser emitido pelo indivíduo envolvido de forma livre, ou seja, sem qualquer coação. Ademais, requer-se que ele seja adequado e esclarecido, o que significa dizer que deve basear-se em uma escolha fundada na apropriada compreensão dos benefícios e danos eventualmente emergentes.

O item $a$ do artigo em referência trata especificamente do consentimento informado que deve ser emitido em casos de intervenções médicas, enquanto os seus itens $b$ e c tratam da aplicação do consentimento informado aos sujeitos de pesquisa. Em qualquer situação, o indíviduo deve expressar vontade manifesta, sendo-lhe permitido revogar seu consentimento a qualquer momento, sem nenhum prejuízo. Ademais, exceções a esta disposição devem ocorrer de acordo com os padrões éticos adotados pelos Estados e em conformidade com as previsões da Declaração. Ressaltamos, ainda, que o item $c$ do artigo ora em comento definiu a necessidade de que um consentimento adicional seja expresso pelo representante de uma comunidade em que seus membros estejam participando

240 "Artigo 6 - Consentimento

a) Qualquer intervenção médica preventiva, diagnóstica e terapêutica só deve ser realizada com o consentimento prévio, livre e esclarecido do indivíduo envolvido, baseado em informação adequada. $\mathrm{O}$ consentimento deve, quando apropriado, ser manifesto e poder ser retirado pelo indivíduo envolvido a qualquer momento e por qualquer razão, sem acarretar desvantagem ou preconceito.

b) A pesquisa científica só deve ser realizada com o prévio, livre, expresso e esclarecido consentimento do indivíduo envolvido. A informação deve ser adequada, fornecida de uma forma compreensível e incluir os procedimentos para a retirada do consentimento. O consentimento pode ser retirado pelo indivíduo envolvido a qualquer hora e por qualquer razão, sem acarretar qualquer desvantagem ou preconceito. Exceções a este princípio somente devem ocorrer quando em conformidade com os padrões éticos e legais adotados pelos Estados, consistentes com as provisões da presente Declaração, particularmente com o Artigo 27 e com os direitos humanos.

Em casos específicos de pesquisas desenvolvidas em um grupo de indivíduos ou comunidade, um consentimento adicional dos representantes legais do grupo ou comunidade envolvida pode ser buscado. Em nenhum caso, o consentimento coletivo da comunidade ou o consentimento de um líder da comunidade ou outra autoridade deve substituir o consentimento informado individual". 
enquanto sujeitos de pesquisa. Não se trata de consentimento substitutivo, já que não se dispensa o consentimento individual de cada participante, mas de requisito extra para a manifestação de um consentimento livre da comunidade.

Importante, por fim, destacar que, em razão dos avanços da genética, surgiu o que se tem chamado de "direito de não ser informado" - que consistiria no direito da pessoa de não querer saber, antecipadamente, se possui alguma doença genética ou a predisposição a desenvolvê-la. Entretanto, muito embora 0 artigo $5^{\circ}$ da Declaração Universal sobre o Genoma Humano e os Direitos Humanos e o art. 10 da Declaração Internacional sobre os Dados Genéticos Humanos já o reconheçam, uma disposição desse tipo seria específica demais para ser incluída em um capítulo dedicado à enunciação de princípios de bioética, conforme esclarecido no item 70 do Relatório Explicativo divulgado pela Unesco ao primeiro rascunho da Declaração ${ }^{241}$.

Igualmente, o artigo $7^{\circ} 242$ aborda o princípio do consentimento informado, determinando sua incidência também no caso de intervenções médicas ou pesquisas em indivíduos sem capacidade para consentir, assim considerados aqueles que, mesmo transitoriamente, não são capazes de fazer escolhas autônomas: em virtude da pouca idade, ignorância, depressão, desespero, doença, ou outros fatores. O artigo em questão assevera que deva ser concedida proteção especial a essas pessoas, sendo que qualquer "autorização para pesquisa e prática médica deve ser obtida no melhor interesse do indivíduo envolvido", levando-se em consideração, sempre que possível, sua própria opinião. Além disso, qualquer pesquisa que os envolva só deve ser realizada se gerar benefícios para a sua

${ }^{241} C f$. Explanatory Memorandum on the elaboration of the preliminary draft Declaration on Universal Norms on Bioethics, disponível no site da Unesco: www.unesco.org.br.

242 “Artigo 7 - Indivíduos sem a Capacidade para Consentir

Em conformidade com a legislação, proteção especial deve ser dada a indivíduos sem a capacidade para fornecer consentimento:

a) a autorização para pesquisa e prática médica deve ser obtida no melhor interesse do indivíduo envolvido e de acordo com a legislação nacional. Não obstante, o indivíduo afetado deve ser envolvido, na medida do possível, tanto no processo de decisão sobre consentimento assim como sua retirada;

a pesquisa só deve ser realizada para o benefício direto à saúde do indivíduo envolvido, estando sujeita à autorização e às condições de proteção prescritas pela legislação e caso não haja nenhuma alternativa de pesquisa de eficácia comparável que possa incluir sujeitos de pesquisa com capacidade para fornecer consentimento. Pesquisas sem potencial benefício direto à saúde só devem ser realizadas excepcionalmente, com a maior restrição, expondo o indivíduo apenas a risco e desconforto mínimos e quando se espera que a pesquisa contribua com o benefício à saúde de outros indivíduos na mesma categoria, sendo sujeitas às 
saúde e caso não haja qualquer alternativa de pesquisa que possa incluir sujeitos de pesquisa capazes de consentir, devendo, ainda, respeitar eventua recusa em participar.

Criticamos, contudo, a segunda parte do item $b$ deste artigo $7^{\circ}$, pois entendemos que ela colide diretamente com o disposto no item $b$ do artigo $3^{\circ}$, o qual afirma que: "os interesses e o bem-estar do indivíduo devem ter prioridade sobre o interesse exclusivo da ciência ou da sociedade". Embora concordemos que alguns direitos fundamentais possam ser restringidos em benefício da sociedade, não acreditamos que tal possibilidade possa ser aceita com relação a indivíduos incapazes de consentir em casos de pesquisas que não lhes tragam benefícios diretos e que lhes possam causar riscos e desconfortos, ainda que mínimos. Até porque a sensação de desconforto e até mesmo a dor é algo pessoal, que na maioria das vezes somente o próprio indivíduo pode mensurar. E, em razão de acreditarmos que essa Declaração possa funcionar como documento inspirador de normas de bioética em muitos dos 191 países-membros da ONU, a crítica aqui engendrada ganha espaço, pois a eventual proteção legal a pesquisas que possam causar danos em sujeitos incapazes de consentir pode dar ensejo a que abusos sejam cometidos em países em que não existam comitês nacionais de bioética atuantes.

Os princípios do respeito pela vulnerabilidade e integridade individual são previstos no artigo $8^{\circ}{ }^{243}$. Tal dispositivo relaciona-se intimamente com o princípio do consentimento informado, pois a vulnerabilidade humana pode influenciar o grau de liberdade de um consentimento concedido. O termo vulnerabilidade refere-se a grupos ou indivíduos fragilizados "jurídica ou politicamente, na promoção, proteção ou garantia de seus direitos de cidadania" ${ }^{244}$. Assim, o indivíduo pode ser considerado vulnerável em função da sua ignorância, depressão, desespero, doença, exclusão social, ou outro fator que possa reduzir sua autonomia para guiar sua própria vida.

condições prescritas por lei e compatíveis com a proteção dos direitos humanos do indivíduo. A recusa de tais indivíduos em participar de pesquisas deve ser respeitada".

243 "Artigo 8 - Respeito pela Vulnerabilidade Humana e pela Integridade Individual A vulnerabilidade humana deve ser levada em consideração na aplicação e no avanço do conhecimento científico, das práticas médicas e de tecnologias associadas. Indivíduos e grupos de vulnerabilidade específica devem ser protegidos e a integridade individual de cada um deve ser respeitada".

${ }^{244}$ ALVES, J. A. L. Os direitos humanos como tema global. São Paulo: Perspectiva, 1994, p. 150. 
Os princípios da privacidade e da confidencialidade, segundo os quais se deve preservar a privacidade dos indivíduos sujeitos a tratamentos médicos ou a pesquisas científicas, respeitando-se, sempre, o sigilo dos dados obtidos, são definidos no artigo $9^{\circ} 245$ da Declaração. Trata-se de dispositivo de imensa relevância para a preservação da dignidade da pessoa humana face aos avanços da genética, vez que, indiretamente, afirma o dever de máxima proteção possível à intimidade genética de um indivíduo. Prevê, assim, a proteção à privacidade em todas as suas dimensões, determinando a confidencialidade dos resultados obtidos, seja em um diagnóstico médico, em um mapa genético ou até mesmo em uma pesquisa em seres humanos, bem como sua estrita utilização para os fins a que foram consentidos.

O artigo $10^{246}$, a seu turno, traz à luz os princípios da igualdade, da justiça e da eqüidade, sobre os quais é de se tecer algumas considerações.

A igualdade pretendida no dispositivo em questão possui dois enfoques: o primeiro deles é o de uma igualdade formal - que determina que se dedique o mesmo tratamento a indivíduos em situação semelhante; o segundo é o de uma igualdade material, que se relaciona diretamente com os princípios da eqüidade e da justiça, funcionando como balisa ética da noção de igualdade formal. A idéia de que todas as pessoas possuem igual dignidade, que é inerente ao ser humano, faz-nos concluir que um tratamento justo e eqüitativo deve-lhes ser concedido, ainda que em prejuízo de uma justiça comutativa. Destacamos, assim, que a igualdade ora proposta reafirma o que fora definido no artigo $1^{\mathbf{o}}$ da Declaração Universal dos Direitos Humanos: que "todos os homens nascem livres e iguais em dignidade e direitos". Agrega-lhe, contudo, o sentido de justiça, eqüidade, solidariedade e cooperação ${ }^{247}$.

\footnotetext{
245 “Artigo 9 - Privacidade e Confidencialidade

A privacidade dos indivíduos envolvidos e a confidencialidade de suas informações devem ser respeitadas. Com esforço máximo possível de proteção, tais informações não devem ser usadas ou reveladas para outros propósitos que não aqueles para os quais foram coletadas ou consentidas, em consonância com o direito internacional, em particular com a legislação internacional sobre direitos humanos".

246 "Artigo 10 - Igualdade, Justiça e Eqüidade

A igualdade fundamental entre todos os seres humanos em termos de dignidade e de direitos deve ser respeitada de modo que todos sejam tratados de forma justa e eqüitativa".

${ }^{247}$ A solidariedade e a cooperação também foram elevadas ao nível de princípios fundamentais da bioética pela presente Declaração (art. 13).
} 
A noção de justiça, por outro lado, é fundamental para a construção de um Estado Democrático de Direito - que se propõe a garantir a fruição dos direitos sociais - e, portanto, tem sido inserida no âmbito dos princípios definidores de direitos humanos. No campo da bioética, as discussões costumeiramente abarcam dimensões concernentes à sociedade, que transpõem os limites da relação médico-paciente e passam a dizer respeito a coletividades. Dessarte, a idéia de justiça, distributiva e social, tem ganhado palco e norteado os debates de bioética, principalmente no que tange à alocação de recursos na área da saúde.

Nesse sentido, a igualdade dos seres-humanos em dignidade é ressaltada no artigo $11^{248}$, afirmando que nenhum indivíduo ou grupo pode ser estigmatizado ou de qualquer forma discriminado.

Importante, contudo, distinguir a formulação de uma discriminação positiva daquela negativa. Somente a discriminação negativa: ilegal, injustificável e degradante da dignidade do indivíduo é coibida. A discriminação positiva, conhecida como ação afirmativa, é aceita. Consiste em intervenção do Estado para a promoção da igualdade material de oportunidades dos cidadãos por meio de políticas públicas e leis que atentem para as especificidades dos grupos menos favorecidos, compensando, desse modo, as eventuais desigualdades decorrentes do processo histórico e da sedimentação cultural. A proibição de discriminação negativa já foi enunciada em diversos outros documentos internacionais, dentre os quais rememoramos o artigo $6^{\circ}$ da Declaração Universal sobre o Genoma Humano e os Direitos Humanos, por ter introduzido o impedimento de discriminação em virtude de informação contida no patrimônio genético de qualquer pessoa. O estigma, a seu turno, pode ser definido como uma marca ou sinal aplicado a uma pessoa ou a um grupo, comumente referido a uma característica indigna ou desonrosa ${ }^{249}$. Sua repressão é dificilmente alcançada por meios estritamente legais e requer uma conscientização social do respeito à diversidade e ao outro enquanto ser-humano. A

\footnotetext{
248 “Artigo 11 - Não-Discriminação e Não-Estigmatização

Nenhum indivíduo ou grupo deve ser discriminado ou estigmatizado por qualquer razão, o que constitui violação à dignidade humana, aos direitos humanos e liberdades fundamentais".

${ }^{249} C f$. definição dada pelo dicionário Houaiss de língua portuguesa ao termo estigma.
} 
educação ética e a valorização da dignidade da pessoa humana outrossim podem exercer papel essencial nesse aprendizado social.

O respeito à diversidade cultural e ao pluralismo são enunciados no artigo $12^{250}$. O item 48 do Relatório Explicativo divulgado pela Unesco ao primeiro rascunho desta Declaração traz relevante definição destes termos, sublinhando que a noção de humanidade decorre das manifestações culturais e não de uma significação biológica - o que claramente justifica o mérito desses princípios.

48. Diversidade cultural refere-se às multifacetadas formas em que as culturas e os diferentes grupos sociais e sociedades encontram expressão. Das diversas formas tomadas por culturas ao longo do tempo e espaço resta a unicidade e pluralidade das identidades e expressões culturais dos povos e socieddaes que dão cor à humanidade ${ }^{251}$.

Ademais, mesmo significado já havia sido concedido pelo artigo $1^{\circ}$ da Declaração Universal da Diversidade Cultural da Unesco, de 2001, ao afirmar que:

A cultura adquire formas diversas através do tempo e do espaço. Essa diversidade se manifesta na originalidade e na pluralidade de identidades que caracterizam os grupos e as sociedades que compõem a humanidade. Fonte de intercâmbios, de inovação e de criatividade, a diversidade cultural é tão necessária para o gênero humano, quanto a diversidade biológica o é para a natureza. Nesse sentido, constitui o patrimônio comum da humanidade e deve ser reconhecida e consolidada em beneficio das gerações presentes e futuras ${ }^{252}$.

Considerando, ainda, que a diversidade cultural evidencia a variabilidade dos valores tidos como fundamentais por uma comunidade localizada no espaço e no

250 "Artigo 12 - Respeito pela Diversidade Cultural e pelo Pluralismo

A importância da diversidade cultural e do pluralismo deve receber a devida consideração. Todavia, tais considerações não devem ser invocadas para violar a dignidade humana, os direitos humanos e as liberdades fundamentais nem os princípios dispostos nesta Declaração, ou para limitar seu escopo".

${ }^{251}$ Tradução livre de: 48. Cultural diversity refers to the manifold ways in which the cultures of different social groups and societies find expression. From the diverse forms taken by culture over time and space stem the uniqueness and plurality of the identities and cultural expressions of the peoples and societies that make up humankind Cf. Explanatory Memorandum on the elaboration of the preliminary draft Declaration on Universal Norms on Bioethics, disponível no site da Unesco: www.unesco.org.br.

${ }^{252}$ Vide site da Unesco no Brasil: www.unesco.org.br/areas/cultura/areastematicas/diversidadecultural. Acessado em 15/09/2006. 
tempo, devemos reiterar que o conteúdo essencial do que seja a dignidade humana também se altera. Destarte, os princípios enunciados nessa Declaração não podem ser simplesmente impostos para países culturalmente tão diferentes. Ao contrário, eles funcionam como nortes para que o sistema legal de cada Estado possa interpretá-los e redigir suas próprias normas concernentes aos temas de bioética. Todavia, consoante previsto no próprio artigo 12 em referência, não se admite que o argumento da diversidade cultural seja utilizado para tornar justas ações que atentem contra a dignidade da pessoa humana. Entendemos que se trate de uma regra de exceção a um princípio, que o restringe em sua aplicabilidade. A mesma construção normativa já havia sido utilizada na Declaração Universal da Diversidade Cultural da Unesco e reafirma a noção de complementaridade dos princípios definidores de direitos humanos, em que cada um - enquanto mandamento de otimização não pode esvaziar o conteúdo valorativo dos demais.

Os princípios da solidariedade e cooperação vêm previstos no artigo $13^{253}$ do documento em tela. Entendemos que esse dispositivo possui a função de importante marco ético da Declaração, pois ressalta que ela não reconhece apenas a importância de direitos individuais, mas afirma a relevância da solidariedade entre indivíduos, entre esses e a sociedade e até mesmo entre Estados. Insere-se, diretamente, no âmbito dos objetivos propostos na Declaração: “promover o acesso eqüitativo aos desenvolvimentos médicos, científicos e tecnológicos, [...] e a participação nos benefícios, com particular atenção às necessidades de países em desenvolvimento" - tendo função norteadora para as questões que envolvem alocação de recursos e proteção de grupos vulneráveis.

\footnotetext{
253 “Artigo 13 - Solidariedade e Cooperação

A solidariedade entre os seres humanos e cooperação internacional para este fim devem ser estimuladas".
} 
Inserido em dimensão igualmente social, o artigo $14^{254}$ aborda a questão da responsabilidade dos governos e de todos os setores da sociedade em relação à promoção da saúde do ser humano. Inclui no conceito de saúde o acesso a cuidados médicos de qualidade, medicamentos essenciais, nutrição adequada e água de boa qualidade, a melhoria das condições de vida e do meio-ambiente, a eliminação da marginalização e da exclusão de indivíduos, bem como a redução da pobreza e do analfabetismo. Tal dever de responsabilidade já vem destacado no preâmbulo da Declaração ao definir a dimensão social em que deve ser analisado o progresso científico. Entendemos que o princípio enunciado nesse artigo encontra-se intimamente relacionado com o da justiça, previsto no artigo 10 da mesma Declaração e em inúmeros outros instrumentos internacionais. Interessante, contudo, observar que a Unesco preocupou-se em explicitar detalhadamente a extensão do que considera como sendo o direito à saúde de qualidade, incluindo a interdependência existente com o direito à educação, ao meio-ambiente sadio e ao desenvolvimento. Mais uma vez, torna clara a complementaridade decorrente dos princípios definidores de direitos humanos.

Em perspectiva igualmente social, de solidariedade e de justiça, o artigo $15^{255}$ aborda a questão do compartilhamento de benefícios. Afirma que a sociedade como

254 “Artigo 14 - Responsabilidade Social e Saúde

a) A promoção da saúde e do desenvolvimento social para a sua população é objetivo central dos governos, partilhado por todos os setores da sociedade.

b) Considerando que usufruir o mais alto padrão de saúde atingível é um dos direitos fundamentais de todo ser humano, sem distinção de raça, religião, convicção política, condição econômica ou social, o progresso da ciência e da tecnologia deve ampliar:

i. o acesso a cuidados de saúde de qualidade e a medicamentos essenciais, incluindo especialmente aqueles para a saúde de mulheres e crianças, uma vez que a saúde é essencial à vida em si e deve ser considerada como um bem social e humano;

ii. o acesso a nutrição adequada e água de boa qualidade;

iii. a melhoria das condições de vida e do meio ambiente;

iv. a eliminação da marginalização e da exclusão de indivíduos por qualquer que seja o motivo;

v. a redução da pobreza e do analfabetismo". 255 "Artigo 15 - Compartilhamento de Benefícios

a) Os benefícios resultantes de qualquer pesquisa científica e suas aplicações devem ser compartilhados com a sociedade como um todo e, no âmbito da comunidade internacional, em especial com países em desenvolvimento. Para dar efeito a esse princípio, os benefícios podem assumir quaisquer das seguintes formas:

(i) ajuda especial e sustentável e reconhecimento aos indivíduos e grupos que tenham participado de uma pesquisa;

(ii) acesso a cuidados de saúde de qualidade;

(iii) oferta de novas modalidades diagnósticas e terapêuticas ou de produtos resultantes da pesquisa;

(iv) apoio a serviços de saúde; 
um todo deve ser destinatária das benesses trazidas pelos avanços científicos - o que inclui, no âmbito internacional, os países em desenvolvimento. Converge, portanto, ao disposto na Declaração Universal sobre o Genoma Humano e Direitos Humanos ${ }^{256}$ e na Declaração sobre Dados Genéticos Humanos ${ }^{257}$ - que priorizam o princípio da solidariedade entre os homens, determinando que ele constitui parâmetro ético norteador de normas de direito interno e internacional. Tal preceito traz, ademais, rol explicativo do que consiste a repartição de benefícios: i. ajuda especial e sustentável e reconhecimento aos indivíduos e grupos que tenham participado de uma pesquisa; ii. acesso a cuidados de saúde de qualidade; iii. oferta de novas modalidades diagnósticas e terapêuticas ou de produtos resultantes da pesquisa; iv. apoio a serviços de saúde; v. acesso ao conhecimento científico e tecnológico; vi. facilidades para geração de capacidade em pesquisa. É de se anotar, entretanto, que as possibilidades de repartição de benefícios não se esgotam no conjunto enunciado neste artigo em razão da natureza materialmente aberta e otimizadora de um princípio - expressamente reconhecida, inclusive, no item a-vii desse dispositivo ao incluir a expressão "outras formas de benefício coerentes com os princípios dispostos na presente Declaração".

O artigo $16^{258}$ da Declaração propõe que o impacto das inovações científicas sobre as gerações futuras deva "ser devidamente considerado". No entanto, não define qualquer obrigação decorrente de uma eventual consideração negativa e nem ao menos faz referência ao princípio da precaução, amplamente consagrado pelo direito internacional. Ao contrário, contentou-se a Unesco com a tímida redação deste artigo, cuja leitura nos faz crer que o princípio de proteção das gerações futuras poderá ficar restrito ao âmbito retórico.

(v) acesso ao conhecimento científico e tecnológico;

(vi) facilidades para geração de capacidade em pesquisa;

(vii) outras formas de benefício coerentes com os princípios dispostos na presente Declaração.

b) Os benefícios não devem constituir indução inadequada para estimular a participação em pesquisa".

${ }^{256}$ Cf. art. 12.

257 Cf. art. 19.

258 "Artigo 16 - Proteção das Gerações Futuras

O impacto das ciências da vida sobre gerações futuras, incluindo sobre sua constituição genética, deve ser devidamente considerado". 
O noção de que a bioética abrange, outrossim, a proteção do meio-ambiente, da biosfera e da diversidade é consolidada no artigo $17^{259}$. A obrigação de preservação do meio-ambiente - reconhecida no preâmbulo da Declaração - está também presente na Declaração da UNESCO sobre as Responsabilidades das Gerações Presentes para com as Gerações Futuras, de 12 de novembro de 1997, premissa normativa do documento ora analisado. Adotou, claramente, concepção unitária do meio-ambiente, que compreende tanto os bens naturais quanto os bens culturais - resultante, inclusive, de uma interpretação sistemática e integrada da Declaração ${ }^{260}$. O meio-ambiente seria, portanto, um conjunto interativo formado por elementos naturais, artificiais e culturais - que devem ser preservados, a fim de que todas as formas de vida possam se desenvolver plenamente.

Quanto à biodiversidade, não pode, igualmente, ser considerada como um fenômeno unicamente natural, pois possui uma extensão cultural. Ela, de fato, não se resume em longas listas de espécies de plantas e animais, descontextualizadas do domínio cultural, porquanto se trata de um conceito construído em relação às populações humanas. Reconhecida a interdependência existente entre os seres-humanos e a biosfera, a conciliação entre a proteção dos interesses econômicos e culturais e o meio-ambiente deve ser almejada. Casos de restrições a estes mandamentos devem ser resolvidos através da ponderação, visando-se à otimização da aplicação de cada um deles.

\subsection{Aplicacão dos princípios enunciados.}

Os artigos seguintes abordam o tema da aplicação dos princípios enunciados na Declaração, apresentando os requisitos considerados necessários para que a sua implementação lhes garanta a maior efetividade possível. Tratam-se, portanto, de regras procedimentais.

\footnotetext{
259 “Artigo 17 - Proteção do Meio Ambiente, da Biosfera e da Biodiversidade

Devida atenção deve ser dada à inter-relação de seres humanos com outras formas de vida, à importância do acesso e utilização adequada de recursos biológicos e genéticos, ao respeito pelo conhecimento tradicional e ao papel dos seres humanos na proteção do meio ambiente, da biosfera e da biodiversidade".

${ }^{260} \mathrm{O}$ artigo $1^{\circ}$ da Declaração sublinha, neste sentido, as dimensões sociais, legais e ambientais do serhumano.
} 
O artigo $18^{261}$ aborda o momento da tomada de decisões em âmbito bioético.

Afirma alguns deveres que devem nortear a aplicação dos princípios supraenunciados: profissionalismo, honestidade, integridade e transparência. Acrescenta que a reflexão ética deve permear todo o processo de decisão acerca de conflitos emergentes do desenvolvimento científico e tecnológico. Além disso, estabelece que todos os indivíduos envolvidos devem ser ouvidos, pois a solução de um conflito de princípios deve ser multidisciplinar: não há uma única resposta possível. A promoção de um diálogo pluralístico sobre temas de bioética na sociedade constitui um dos objetivos dessa Declaração, conforme enunciado em seu artigo $2^{\circ}$.

O artigo $19^{262}$, por sua vez, fixa a importância da existência de comitês de ética independentes, multidisciplinares e pluralistas para a implementação da Declaração. As funções exercidas por eles seriam múltiplas, envolvendo desde a avaliação de questões éticas abarcadas por pesquisas em seres humanos ou casos clínicos até mesmo sua participação ativa na promoção do debate público de temas de bioética. Ademais, o Relatório Explicativo divulgado pela Unesco ao primeiro rascunho da Declaração ${ }^{263}$ reafirma que a atuação desses comitês requer independência, multidisciplinariedade e respeito ao pluralismo. Devem atuar intensamente na avaliação das novas técnicas desenvolvidas pela ciência biomédica e tecnologias relacionadas, além de prestar aconselhamento nos casos de dilemas éticos suscitados em âmbito clínico.

261 “Artigo 18 - Tomada de Decisão e o Tratamento de Questões Bioéticas

a) Devem ser promovidos o profissionalismo, a honestidade, a integridade e a transparência na tomada de decisões, em particular na explicitação de todos os conflitos de interesse e no devido compartilhamento do conhecimento. Todo esforço deve ser feito para a utilização do melhor conhecimento científico e metodologia disponíveis no tratamento e constante revisão das questões bioéticas.

b) Os indivíduos e profissionais envolvidos e a sociedade como um todo devem estar incluídos regularmente num processo comum de diálogo.

c) Deve-se promover oportunidades para o debate público pluralista, buscando-se a manifestação de todas as opiniões relevantes".

262 "Artigo 19 - Comitês de Ética

Comitês de ética independentes, multidisciplinares e pluralistas devem ser instituídos, mantidos e apoiados em nível adequado com o fim de:

i. avaliar questões éticas, legais, científicas e sociais relevantes relacionadas a projetos de pesquisa envolvendo seres humanos;

ii. prestar aconselhamento sobre problemas éticos em situações clínicas;

iii. avaliar os desenvolvimentos científicos e tecnológicos, formular recomendações e contribuir para a elaboração de diretrizes sobre temas inseridos no âmbito da presente Declaração;

iv.promover o debate, a educação, a conscientização do público e o engajamento com a bioética". 
De fato, propõe a Declaração a constante avaliação e gerenciamento de riscos decorrentes de atividades exercidas pela medicina, ciências da vida e tecnologias associadas, conforme se vê de seu artigo $20^{264}$. Importante, contudo, consignar que a Declaração não define o que considera como sendo o risco aceitável decorrente dos avanços da ciência. Ou seja, ao propor a avaliação dos riscos indica, ainda que implicitamente, que haveria um nível que seria inerente à utilização de técnicas criadas pelo homem na área biomédica e tecnológica - concepção que se coaduna com a teoria da sociedade do risco, preconizada por Ulrich Beck. Não menciona, contudo, os critérios que poderão definir o limite de tais riscos - o que impossibilita, de certa forma, sua realização prática.

As práticas transnacionais no campo da bioética são abordadas no artigo $21^{265}$ - questão de grande relevância para uma Declaração de cunho universalista, que pretende definir diretrizes éticas globais. Estabelece normas de conduta para os Estados em pesquisas transnacionais, enfatizando, principalmente, a aplicação dos princípios da solidariedade, igualdade e autonomia. É de se ressaltar a previsão contida no item e do dispositivo em referência - que trata do bioterrorismo: tráfico ilícito de órgãos, tecidos, amostras, recursos e materiais genéticos -, propondo, claramente, a idéia de uma guerra contra o terrorismo no âmbito da bioética, defendida sob o comando dos Estados Unidos.

${ }^{263} C f$. Explanatory Memorandum on the elaboration of the preliminary draft Declaration on Universal Norms on Bioethics, disponível no site da Unesco: www.unesco.org.br.

264 “Artigo 20 - Avaliação e Gerenciamento de Riscos

Deve-se promover a avaliação e o gerenciamento adequado de riscos relacionados à medicina, às ciências da vida e às tecnologias associadas".

265 “Artigo 21 - Práticas Transnacionais

a) Os Estados, as instituições públicas e privadas, e os profissionais associados a atividades transnacionais devem empreender esforços para assegurar que qualquer atividade no escopo da presente Declaração que seja desenvolvida, financiada ou conduzida de algum modo, no todo ou em parte, em diferentes Estados, seja coerente com os princípios da presente Declaração.

b) Quando a pesquisa for empreendida ou conduzida em um ou mais Estados [Estado(s) hospedeiro(s)] e financiada por fonte de outro Estado, tal pesquisa deve ser objeto de um nível adequado de revisão ética no(s) Estado(s) hospedeiro(s) e no Estado no qual o financiador está localizado. Esta revisão deve ser baseada em padrões éticos e legais consistentes com os princípios estabelecidos na presente Declaração.

c) Pesquisa transnacional em saúde deve responder às necessidades dos países hospedeiros e deve ser reconhecida sua importância na contribuição para a redução de problemas de saúde globais urgentes.

d) $\quad \mathrm{Na}$ negociação de acordos para pesquisa, devem ser estabelecidos os termos da colaboração e a concordância sobre os benefícios da pesquisa com igual participação de todas as partes na negociação.

e) Os Estados devem tomar medidas adequadas, em níveis nacional e internacional, para combater o bioterrorismo e o tráfico ilícito de órgãos, tecidos, amostras, recursos genéticos e materiais genéticos". 
A importância da participação de cada Estado-membro na efetivação das disposições contidas na Declaração é sublinhada no artigo $22^{266}$, o qual consigna o dever de que sejam tomadas medidas de caráter legislativo e administrativo interno, que sejam capazes de implementar os princípios nela contidos no sistema jurídico de cada paísmembro. Ademais, complementarmente, o artigo $23^{267}$ destaca a importância que deve ser concedida à educação em bioética - afirmando, ademais, que os Estados devem promover e fomentar programas de disseminação de informações e conhecimentos relacionados aos temas por ela debatidos e que não se prescinde de pessoas com formação específica no assunto, para o funcionamento adequado dos Comitês Nacionais de Bioética propostos pela Unesco. Ressaltamos, ainda, com base em uma interpretação sistemática da Declaração, que a educação em bioética deve ultrapassar os limites dos Comitês e até mesmo da área da saúde, passando a abarcar a sociedade como um todo. Faz-se necessário que se preparem os cidadãos para discutirem sobre os temas de bioética, uma vez que somente através de interlocutores preparados e capazes de articular argumentos coerentes será possível estabelecer-se um debate ético.

\footnotetext{
266 "Artigo 22 - Papel dos Estados

a) Os Estados devem tomar todas as medidas adequadas de caráter legislativo, administrativo ou de qualquer outra natureza, de modo a implementar os princípios estabelecidos na presente Declaração e em conformidade com o direito internacional e com os direitos humanos. Tais medidas devem ser apoiadas por ações nas esferas da educação, formação e informação ao público.

b) Os Estados devem estimular o estabelecimento de comitês de ética independentes, multidisciplinares e pluralistas, conforme o disposto no Artigo 19".

267 "Artigo 23 - Informação, Formação e Educação em Bioética

a) De modo a promover os princípios estabelecidos na presente Declaração e alcançar uma melhor compreensão das implicações éticas dos avanços científicos e tecnológicos, em especial para os jovens, os Estados devem envidar esforços para promover a formação e educação em bioética em todos os níveis, bem como estimular programas de disseminação de informação e conhecimento sobre bioética.

b) Os Estados devem estimular a participação de organizações intergovernamentais, internacionais e regionais e de organizações não-governamentais internacionais, regionais e nacionais neste esforço".
} 
$\mathrm{O}$ artigo $24^{268}$ aborda o tema do dever de cooperação internacional. Trata-se da afirmação da dimensão transnacional do princípio da solidariedade - que impõe que os Estados promovam o compartilhamento de informações científicas e tecnológicas. É certo que a promoção da solidariedade entre Estados assume essencial importância quando nos referimos aos países em desenvolvimento, pois com relação a eles a cooperação internacional de conhecimentos científicos, know-how e tecnologias associadas é fundamental para que suas populações tenham acesso a novas terapias, métodos modernos de diagnóstico e melhora na sua qualidade de vida. Infelizmente, trata-se de mais um exemplo retórico de justiça distributiva - extremamente distante da realidade concernente aos monopólios de pesquisas detidos por grandes empresas.

O artigo $25^{269}$ reafirma o compromisso da Unesco com os princípios de bioética proclamados na Declaração - prevendo um processo de acompanhamento contínuo de sua realização que contará com o apoio do Comitê Intergovernamental de Bioética (IGBC) e do Comitê Internacional de Bioética (IBC).

$\mathrm{O}$ artigo $26^{270}$, a seu turno, consiste em um enunciado hermenêutico, afirmando a unidade da Declaração - da qual decorre a complementaridade dos princípios nela enunciados. Não existe, portanto, hierarquia a priori entre eles, mas somente se pode

\footnotetext{
268 “Artigo 24 - Cooperação Internacional

a) Os Estados devem promover a disseminação internacional da informação científica e estimular a livre circulação e o compartilhamento do conhecimento científico e tecnológico.

b) Ao abrigo da cooperação internacional, os Estados devem promover a cooperação cultural e científica e estabelecer acordos bilaterais e multilaterais que possibilitem aos países em desenvolvimento construir capacidade de participação na geração e compartilhamento do conhecimento científico, do knowhow relacionado e dos benefícios decorrentes.

c) Os Estados devem respeitar e promover a solidariedade entre Estados, bem como entre indivíduos, famílias, grupos e comunidades, com atenção especial para aqueles tornados vulneráveis por doença ou incapacidade ou por outras condições individuais, sociais ou ambientais e aqueles indivíduos com maior limitação de recursos".

269 “Artigo 25 - Ação de Acompanhamento pela UNESCO

a) A UNESCO promoverá e disseminará os princípios da presente Declaração. Para tanto, a UNESCO buscará apoio e assistência do Comitê Intergovernamental de Bioética (IGBC) e do Comitê Internacional de Bioética (IBC).

b) A UNESCO reafirmará seu compromisso em tratar de bioética e em promover a colaboração entre o IGBC e o IBC".

270 "Artigo 26 - Inter-relação e Complementaridade dos Princípios

A presente Declaração deve ser considerada em sua totalidade e seus princípios devem ser compreendidos como complementares e inter-relacionados. Cada princípio deve ser interpretado no contexto dos demais, de forma pertinente e adequada a cada circunstância".
} 
proceder ao estabelecimento de uma ordem de prevalência de princípios diante do caso concreto - através de procedimento decisório que identifique os mandamentos aplicáveis, eventualmente em conflito, e proceda ao seu sopesamento fundamentado, a fim de que se alcance a máxima otimização e mínima restrição dos princípios envolvidos. E somado a este enunciado, o artigo $27^{271}$ sublinha que restrições aos princípios contidos na presente Declaração devem ocorrer em conformidade com a legislação interna e internacional sobre direitos humanos.

O artigo $28^{272}$ - último da Declaração - afirma que nenhum dispositivo dela poderá ser invocado por qualquer Estado, grupo ou indivíduo para justificar o envolvimento ou a prática de atos contrários aos direitos humanos, às liberdades fundamentais e à dignidade humana. Trata-se de uma regra hermenêutica de redação expressiva, sendo certo contudo, que não se deve olvidar que, em razão da natureza relativa e otimizadora dos princípios, situações de colisões entre eles são inevitáveis. Nesses casos, a realização de um princípio significa a limitação do outro - o que, entretanto, não pode ser considerado como uma violação de direitos humanos.

\section{Declaração Universal sobre o Genoma Humano e os Direitos}

\section{$\underline{\text { Humanos }}$}

A Declaração Universal sobre o Genoma Humano e os Direitos Humanos, publicada em 11 de novembro de 1997 e elaborada pelo Comitê de Especialistas Governamentais da UNESCO, estabelece limites éticos a serem obedecidos nas pesquisas genéticas, especialmente naquelas em que há intervenção sobre o patrimônio genético do

\footnotetext{
271 "Artigo 27 - Limitações à Aplicação dos Princípios
}

Se a aplicação dos princípios da presente Declaração tiver que ser limitada, tal limitação deve ocorrer em conformidade com a legislação, incluindo a legislação referente aos interesses de segurança pública para a investigação, constatação e acusação por crimes, para a proteção da saúde pública ou para a proteção dos direitos e liberdades de terceiros. Quaisquer dessas legislações devem ser consistentes com a legislação internacional sobre direitos humanos".

272 “Artigo 28 - Recusa a Atos Contrários aos Direitos Humanos, às Liberdades Fundamentais e Dignidade Humana 
ser-humano. A criação de um Comitê Internacional de Bioética pela UNESCO insere-se no contexto de desenvolvimento do Projeto Genoma Humano e deixa claro o intuito desse órgão das Nações Unidas de controlar e estabelecer limites às pesquisas e aplicação de técnicas de manipulação genética - apesar de reconhecer que a pesquisa do genoma humano abre vastas perspectivas para o progresso, especialmente quanto ao aprimoramento da saúde da humanidade. ${ }^{273}$

O documento visa, portanto, a estabelecer parâmetros éticos e legais para o exercício da atividade científica que sejam capazes de resguardar o genoma humano. Dessarte, a dignidade humana - compartilhada por todos os seres humanos independentemente de suas características genéticas - constitui o fundamento e fio condutor dos temas nela abordados. Dela decorre a obrigatoriedade do respeito à liberdade e aos direitos humanos das pessoas envolvidas nas pesquisas sobre o patrimônio genético e a vedação de qualquer discriminação baseada em características genéticas ${ }^{274}$.

O preâmbulo da Declaração rememora princípios marcadamente reconhecidos pela Unesco e em outros documentos internacionais de proteção dos direitos humanos: dignidade, igualdade, respeito mútuo entre homens e raças. Tal menção aos tratados e convenções de direitos humanos proclamados anteriormente insere, portanto, a presente Declaração no sistema internacional de proteção de tais direitos - que deve ser interpretado de forma orgânica. Além disso, a Declaração proclama que "a ampla difusão da cultura e a educação da humanidade para a justiça, liberdade e a paz são indispensáveis à dignidade dos homens e constituem um dever que todas as nações devem cumprir em

Nada nesta Declaração pode ser interpretado como podendo ser invocado por qualquer Estado, grupo ou indivíduo, para justificar envolvimento em qualquer atividade ou prática de atos contrários aos direitos humanos, às liberdades fundamentais e à dignidade humana".

273 Nesse sentido, anota Stela Barba que "a análise do genoma permite não só conhecer melhor os mecanismos das funções genéticas como também prevenir e tratar doenças. Contudo, a hominicultura acarreta riscos extraordinariamente grandes. Quando orientada para finalidades diferentes pode levar a resultados bastante pejorativos ao possibilitar determinar de modo precoce as características da pessoa e os seus efeitos hereditários antes que se cheguem a revelar. Configura um elemento de ilegítima discriminação social (ex: em questões de emprego, contratos de seguros, etc.) com as pessoas a serem 'etiquetadas' pelos genes". BARBA, Stela Marcos de Almeida. Dissertação apresentada à Faculdade de Direito de Coimbra. 2004, p, 204.

${ }^{274}$ Neste sentido, o artigo 10 da Declaração expressamente define que "nenhuma pesquisa do genoma humano ou das suas aplicações, em especial nos campos da biologia, genética e medicina, deverá prevalecer sobre o respeito aos direitos humanos, às liberdades fundamentais e à dignidade humana de pessoas ou, quando aplicável, de grupos de pessoas". 
espírito de assistência e preocupação mútuas" e que a paz deve ser alicerçada na solidariedade intelectual e moral da humanidade.

O título I da Declaração é denominado "dignidade humana e genoma humano", do que se conclui, desde já, que a proteção do código genético humano é incluída no conteúdo valorativo da dignidade humana. $O$ genoma humano é definido, simbolicamente, como sendo o legado da humanidade, herança que constitui a unidade fundamental de todos os seres humanos - do que decorre a noção de que ele, enquanto identidade genética de cada ser-humano, determina a proteção da igualdade e da diferença. Igualdade porque ele define cada indivíduo como membro da humanidade e diferença porque as características genéticas são pessoais e preservam a diversidade na unidade humana. Assim, independentemente de suas características genéticas, cada ser-humano deve ser protegido. Nesse mesmo sentido, o artigo $6^{\circ}$ determina que "ninguém poderá ser discriminado com base nas suas características genéticas de forma que viole ou tenha o efeito de violar os direitos humanos, as liberdades fundamentais e a dignidade humana". Ainda, sendo espécie de direito personalíssimo, o genoma humano não deve levar a lucro financeiro, conforme definido no art. $4^{\circ}$ da Declaração ${ }^{275}$.

\footnotetext{
275 “Artigo 1: O genoma humano constitui a base da unidade fundamental de todos os membros da família humana, assim como do reconhecimento de sua inerente dignidade e diversidade. Em sentido simbólico, é o legado da humanidade.

Artigo 2:

a) Toda pessoa tem o direito de respeito a sua dignidade e seus direitos, independentemente de suas características genéticas.

b) Essa dignidade torna imperativo que nenhuma pessoa seja reduzida a suas características genética e que sua singularidade e diversidade sejam respeitadas.

Artigo 3: O genoma humano, que por natureza evolui, é sujeito a mutações. Contém potenciais que são expressados diferentemente, de acordo com os ambientes natural e social de cada pessoa, incluindo seu estado de saúde, suas condições de vida, sua nutrição e sua educação.

Artigo 4: O genoma humano no seu estado natural não deve levar a lucro financeiro.

$[\ldots]$

Artigo 6: Ninguém poderá ser discriminado com base nas suas características genéticas de forma que viole ou tenha o efeito de violar os direitos humanos, as liberdades fundamentais e a dignidade humana".
} 
$\mathrm{O}$ artigo $5^{\mathrm{o}} 276$ trata dos exames e pesquisas que envolvam o genoma humano, prevendo que eles somente serão realizados após avaliação rigorosa dos riscos e benefícios associados, devendo sempre respeitar todas as normas legais do país em que são desenvolvidos. Acrescenta-se a exigência do consentimento livre e esclarecido do sujeito de pesquisa ou sob exame - sendo certo que no caso dos incapazes, o artigo $5^{\circ}$ determina que tal consentimento deve ser regido pela legislação vigente, sempre respeitando os interesses da pessoa. Quanto aos resultados da pesquisa, o próprio sujeito deve ter total liberdade para decidir se quer ou não ser informado deles.

Importante, por outro lado, destacar o item e do artigo $5^{\circ}$, o qual afirma que:

Se, de acordo com a legislação, a pessoa tiver capacidade de autodeterminação, a pesquisa relativa ao seu genoma só poderá ser realizada em benefício direto de sua saúde, sempre que previamente autorizada e sujeita às condições de proteção estabelecidas na legislação vigente. Pesquisa que não se espera traga benefício direto à saúde só poderá ser realizada excepcionalmente, com o maior controle, expondo a pessoa a risco e ônus mínimos, sempre que essa pesquisa traga benefícios de saúde a outras pessoas na mesma faixa etária ou com a mesma condição genética, dentro das condições estabelecidas na lei, e contanto que essa pesquisa seja compatível com a proteção dos direitos humanos da pessoa.

Tal dispositivo visa à maximização do princípio da beneficência do paciente e sujeito de pesquisa, precisando critérios para sua eventual restrição. A realização de

\footnotetext{
276 "Artigo 5
}

a) Qualquer pesquisa, tratamento ou diagnóstico que afete o genoma de uma pessoa só será realizado após uma avaliação rigorosa dos riscos e benefícios associados a essa ação e em conformidade com as normas e os princípios legais no país.

b) Obter-se-á, sempre, o consentimento livre e esclarecido da pessoa. Se essa pessoa não tiver capacidade de autodeterminação, obter-se-á consentimento ou autorização conforme a legislação vigente e com base nos interesses da pessoa.

c) Respeitar-se-á o direito de cada pessoa de decidir se quer, ou não, ser informada sobre os resultados do exame genético e de suas conseqüências.

d) No caso de pesquisa, submeter-se-ão, antecipadamente, os protocolos para revisão à luz das normas e diretrizes de pesquisa nacionais e internacionais pertinentes.

e) Se, de acordo com a legislação, a pessoa tiver capacidade de autodeterminação, a pesquisa relativa ao seu genoma só poderá ser realizada em benefício direto de sua saúde, sempre que previamente autorizada e sujeita às condições de proteção estabelecidas na legislação vigente. Pesquisa que não se espera traga benefício direto à saúde só poderá ser realizada excepcionalmente, com o maior controle, expondo a pessoa a risco e ônus mínimos, sempre que essa pesquisa traga benefícios de saúde a outras pessoas na mesma faixa etária ou 
pesquisa que não traga benefícios direitos à saúde do indivíduo somente será aceita em caráter excepcional, desde que se trate de pessoa capaz e ela o exponha a risco e ônus mínimos e traga benefícios para a saúde de outras pessoas na mesma faixa etária ou com a mesma condição genética. Em qualquer caso, os protocolos de pesquisa deverão ser avaliados por comitê de ética, à luz das normas e diretrizes nacionais e internacionais de proteção do genoma humano.

O artigo $7^{\text {o } 277}$ aborda o tema da confidencialidade, impondo-a, como regra geral, para o tratamento dos dados genéticos de pessoa identificada armazenados ou processados para efeito de pesquisa. Eventual restrição a esse direito deve observar os limites previstos no artigo $9^{\circ} 278$ da Declaração: imperiosas razões, determinações legais internas, princípios do direito público internacional e a convenção internacional de direitos humanos - e, segundo entendemos, deve vir acompanhada de decisão fundamentada, por constituir exceção à regra geral de confidencialidade.

O artigo $8^{\text {o }}{ }^{279}$ prevê a responsabilização daquele que causar dano direto ou indireto a pessoa em função de intervenção em seu genoma. Interessante destacar, todavia, que tal dispositivo não determina se a responsabilidade do agente causador do dano seria objetiva ou não, remetendo-nos à legislação nacional sobre responsabilidade civil.

O artigo $11^{280}$ prevê a vedação de práticas científicas contrárias à dignidade humana, dentre as quais incluída a clonagem reprodutiva de seres humanos. Tal proibição

com a mesma condição genética, dentro das condições estabelecidas na lei, e contanto que essa pesquisa seja compatível com a proteção dos direitos humanos da pessoa".

277 “Artigo 7: Os dados genéticos relativos a pessoa identificável, armazenados ou processados para efeitos de pesquisa ou qualquer outro propósito de pesquisa, deverão ser mantidos confidenciais nos termos estabelecidos na legislação".

278 “Artigo 9: Com vistas a proteger os direitos humanos e as liberdades fundamentais, qualquer restrição aos princípios de consentimento e confidencialidade só poderá ser estabelecida mediante lei, por razões imperiosas, dentro dos limites estabelecidos no direito público internacional e a convenção internacional de direitos humanos".

279 “Artigo 8: Toda pessoa tem direito, em conformidade com as normas de direito nacional e internacional, a reparação justa de qualquer dano havido como resultado direto e efetivo de uma intervenção que afete seu genoma".

280 “Artigo 11: Não é permitida qualquer prática contrária à dignidade humana, como a clonagem reprodutiva de seres humanos. Os Estados e as organizações internacionais pertinentes são convidados a cooperar na identificação dessas práticas e na implementação, em níveis nacional ou internacional, das medidas necessárias para assegurar o respeito aos princípios estabelecidos na presente Declaração". 
foi repetida pela Declaração Universal de Bioética e Direitos Humanos de 2005, detalhadamente comentada no presente trabalho.

O artigo $12^{281}$ faz referência, ainda que implícita, aos princípios da solidariedade e da autonomia. O item $a$ do artigo ressalta a importância da disponibilização pública dos benefícios resultantes de pesquisas com o genoma humano - o que nos remete à máxima da participação solidária e eqüitativa da humanidade em relação a um legado de todos: o genoma. O princípio da liberdade está consignado no item $b$, que define a liberdade de pesquisa como sendo espécie do gênero liberdade de pensamento. Importante consignar que tal liberdade não é absoluta, como, inclusive, não o é nenhum princípio definidor de direito fundamental, devendo ser ponderado no caso concreto, de modo a concretizar na maior medida o conteúdo valorativo da dignidade da pessoa humana.

$\mathrm{O}$ artigo $13^{282}$ aborda a questão da responsabilidade dos pesquisadores, determinando que devem atuar com "cautela, honestidade intelectual e integridade na realização de pesquisas". Ou seja, a Declaração sublinhou a responsabilidade ética que deve nortear a atuação dos investigadores científicos. Entretanto, ressaltamos que, no ordenamento jurídico brasileiro, referida responsabilidade é sempre ética e legal, sendo que uma conduta danosa pode dar origem, em certos casos, à obrigação de indenizar.

281 “Artigo 12:

a) Os benefícios resultantes de progresso em biologia, genética e medicina, relacionados com o genoma humano, deverão ser disponibilizados a todos, com as devidas salvaguardas à dignidade e aos direitos humanos de cada pessoa.

b) A liberdade de pesquisar, necessária ao avanço do conhecimento, é parte da liberdade de pensamento. As aplicações da pesquisa, incluindo as aplicações nos campos de biologia, genética e medicina, relativas ao genoma humano, deverão visar ao alívio do sofrimento e à melhoria da saúde das pessoas e da humanidade como um todo".

282 "Artigo 13: Dar-se-á atenção especial às responsabilidades inerentes às atividades dos pesquisadores, incluindo meticulosidade, cautela, honestidade intelectual e integridade na realização de pesquisa, bem como na apresentação e utilização de achados de pesquisa, no âmbito da pesquisa do genoma humano, devido a suas implicações éticas e sociais. As pessoas responsáveis pela elaboração de políticas públicas e privadas no campo das ciências também têm responsabilidade especial nesse respeito". 
Os artigos 14, 15, 16, 17 e $18^{283}$ tratam da atuação dos Estados no âmbito de proteção do genoma humano. Eles devem promover condições materiais e intelectuais favoráveis para que a pesquisa possa se desenvolver, assim como estabelecer medidas de salvaguarda dos direitos humanos e dos princípios enumerados na Declaração em referência. Devem, para tanto, valer-se de comitês de ética em pesquisas interdisciplinares, independentes e pluralistas, e de medidas legais de proteção. Cabe-lhes, ainda, a promoção da solidariedade em relação às pessoas vulneráveis em virtude de doença ou incapacidade genética, em favor das quais se devem envidar esforços de tratamento e fomento de investigações para prevenção de enfermidades. Por fim, os Estados devem continuar a conceder importância à cooperação científica e cultural entre países industrializados e em desenvolvimento - o que demonstra o interesse da Unesco em promover a solidariedade e a cooperação internacional, as quais visariam a incentivar as medidas descritas no artigo 19:

1. realizar uma avaliação dos riscos e benefícios da pesquisa sobre o genoma humano e prevenir abusos;

2. desenvolver e fortalecer a capacidade dos países em desenvolvimento de realizar pesquisa em biologia e genética humanas, levando em consideração os problemas específicos de cada país;

\footnotetext{
283 “Artigo 14: Os Estados deverão tomar medidas apropriadas para promover condições intelectuais e materiais favoráveis à liberdade de pesquisar o genoma humano e considerar as implicações éticas, jurídicas, sociais e econômicas dessa pesquisa, com base nos princípios estabelecidos na presente Declaração.

Artigo 15: Os Estados deverão tomar as medidas necessárias ao estabelecimento de um ambiente adequado ao livre exercício da pesquisa sobre o genoma humano, respeitando-se os princípios estabelecidos na presente Declaração, a fim de salvaguardar os direitos humanos, as liberdades fundamentais e a dignidade humana e proteger a saúde pública. Os Estados deverão procurar assegurar que os resultados das pesquisas não são utilizados para propósitos não pacíficos.

Artigo 16: Os Estados deverão reconhecer o valor de promover, nos vários níveis, conforme apropriado, o estabelecimento de comitês de ética pluralistas, multidisciplinares e independentes, com o propósito de avaliar as questões éticas, legais e sociais levantadas pela pesquisa do genoma humano e de suas aplicações

Artigo 17: Os Estados deverão respeitar e promover a prática da solidariedade em relação a pessoas, famílias e grupos populacionais particularmente vulneráveis a doença ou incapacidade de natureza genética, ou por elas afetados. Os Estados deverão promover, entre outros, pesquisa visando à identificação, à prevenção e ao tratamento de doenças de base genética ou influenciadas pela genética, em especial doenças raras e endêmicas que afetem grande número de pessoas na população mundial.

Artigo 18: Os Estados deverão envidar esforços, com devida e apropriada atenção aos princípios estabelecidos na presente Declaração, para continuar a promover a divulgação internacional de conhecimentos relativos ao genoma humano, à diversidade humana e à pesquisa genética e, nesse respeito, promover a cooperação científica e cultural, em especial entre países industrializados e países em desenvolvimento".
} 
3. beneficiar os países em desenvolvimento, como resultado das realizações da pesquisa científica e tecnológica, de maneira que seu uso, em prol do progresso econômica e social, possa beneficiar a todos;

4. promover o livre intercâmbio de conhecimentos e informações científicas nas áreas de biologia, genética e medicina.

Demais disso, no que concerne, especificamente, ao tema da cooperação internacional no âmbito da bioética aplicada à genética, Pereira tece o seguinte comentário:

Como marco da cooperação internacional com os países em desenvolvimento, os Estados deverão prevenir os abusos e evitar riscos de investigação sobre o genoma humano e contribuir para o desenvolvimento e fortalecimento da capacidade destes países de realizar investigações nas áreas da biologia e da genética e, também, para que estes países possam tirar proveito dos resultados das investigações científicas e tecnológicas a fim de que sua utilização em prol do progresso econômico e social possa redundar em benefício de todos; por meio de livre intercâmbio do conhecimento e da informação científica $^{284}$.

Quanto à promoção dos princípios da Declaração ${ }^{285}$, ela deve, com base no artigo $20^{286}$, ser feita através de intervenções educacionais e de capacitação de profissionais em bioética, especialmente aqueles que atuam em política científica. Ademais, os Estados deverão adotar medidas de conscientização da sociedade quanto à importância da promoção da dignidade humana e da proteção do patrimônio genético da humanidade. Discussões sobre temas polêmicos correlatos devem ser regidas pelo princípio da liberdade de expressão das diversas opiniões socioculturais, religiosas e filosóficas - conforme objetivo

\footnotetext{
${ }^{284}$ PEREIRA, Renata Braga da Silva. DNA: Análise biojurídica da identidade humana. In: Temas de bioética e biodireito. Heloisa Helena Barboza e Vicente de Paulo Barreto (org.). Rio de Janeiro: Renovar, 2005, p. 287.

${ }^{285}$ Nesse sentido, o artigo 22 afirma que "os Estados deverão envidar esforços para promover os princípios estabelecidos na presente Declaração e facilitar sua implementação através de medidas apropriadas".

286 “Artigo 20: Os Estados deverão tomar as medidas necessárias para promover os princípios estabelecidos na presente Declaração, mediante intervenções educacionais e de outra natureza, como a realização de pesquisa e treinamento em campos interdisciplinares e a promoção de capacitação em bioética, em todos os níveis, em especial para os responsáveis pela política científica”.
} 
constante no artigo $21^{287}$. Complementarmente, o artigo $23^{288}$ determina que os Estados promovam o reconhecimento e implementação da Declaração, encorajando a sua aplicação por comitês de ética. A própria Unesco ressalta que contribuirá, através do seu Comitê Internacional de Bioética para a divulgação dos princípios ora estabelecidos, disponibilizando assessoria aos Estados e consultas aos grupos vulneráveis ${ }^{289}$.

Finalmente, o artigo $25^{290}$ define que nenhuma disposição da Declaração poderá ser interpretada de modo a justificar ação atentatória aos direitos humanos proteção que, manifestamente, inclui os princípios ora declarados, que se referem ao patrimônio genético humano, na nova dimensão de proteção desses direitos.

Concluímos este tópico sublinhando que a Declaração em referência tem caráter universalista, pois prevê princípios, exigências e vedações que seriam aplicáveis a todos os seres humanos e, claramente, marca a ampliação do rol de direitos humanos, para abranger no âmbito de sua proteção o patrimônio genético e o próprio ser humano no contexto de manipulações genéticas. Tem-se, então, redefinido o conteúdo da dignidade da pessoa humana, para incluir tais direitos na sua extensão protetiva. Ademais, paulatinamente, a ampla aceitação dos princípios ora declarados e sua inserção nas

\footnotetext{
287 “Artigo 21: Os Estados deverão tomar medidas apropriadas para incentivar outras formas de pesquisa, capacitação e divulgação de informações que promovam a conscientização da sociedade e de todos seus membros acerca de sua responsabilidade em questões fundamentais relativas à proteção da dignidade humana, que possam ser levantadas por pesquisa nos campos da biologia, genética e medicina, e por suas aplicações. Os Estados também deverão facilitar a discussão aberta desse assunto, assegurando a liberdade de expressão das diversas opiniões socioculturais, religiosas e filosóficas".

288 "Artigo 23: Os Estados deverão tomar medidas apropriadas para promover, por meio de treinamento, capacitação e divulgação de informações, o respeito aos princípios antes mencionados, assim como incentivar seu reconhecimento e sua efetiva aplicação. Os Estados também deverão encorajar o intercâmbio e a articulação entre comitês de ética independentes, à medida que forem estabelecidos, de maneira a promover sua plena colaboração".

289 Cf. Artigo 24: "O Comitê Internacional de Bioética da Unesco deverá contribuir à divulgação dos princípios estabelecidos na presente Declaração e aprofundar o estudo das questões levantadas por sua aplicação e pela evolução dessas tecnologias. Deverá organizar consultas com as partes interessadas, como os grupos vulneráveis. Em conformidade com os procedimentos estatutários, deverá formular recomendações para a Conferência Geral da Unesco e prover assessoria relativa ao acompanhamento desta Declaração, em especial quanto à identificação de práticas que possam ir de encontro à dignidade humana, como as intervenções em linhas de germes".

290 “Artigo 25: Nenhuma disposição da presente Declaração poderá ser interpretada como o reconhecimento a qualquer Estado, grupo, ou pessoa, do direito de exercer qualquer atividade ou praticar qualquer ato contrário aos direitos humanos e às liberdades fundamentais, incluindo os princípios aqui estabelecidos".
} 
legislações internas dos Estados poderá consagrá-los como costume internacional, concedendo-os força jurídica incontroversa.

\section{Declaração Internacional sobre os Dados Genéticos Humanos}

No dia 16 de Outubro de 2004, a Unesco aprovou por unanimidade a Declaração Internacional sobre os Dados Genéticos Humanos, complementando os dispositivos da Declaração Universal sobre o Genoma Humano e os Direitos Humanos de 1997. O prefácio à Declaração define que seu maior objetivo seria "garantir o respeito da dignidade humana e a proteção dos direitos humanos e das liberdades fundamentais em matéria de recolhimento, tratamento, utilização e conservação de dados genéticos humanos"291, de modo que se coadune com os imperativos de igualdade, justiça e solidariedade. Ou seja, ela estabelece princípios que visam a fornecer orientações práticas para o tratamento das questões éticas decorrentes das novas descobertas relativas aos genes humanos. Tais princípios “deverão orientar os Estados na formulação das suas legislações e das suas políticas sobre tais matérias" ${ }^{292}$, servindo como parâmetro ético para a regulamentação interna do tratamento desses dados. A Unesco propõe-se, ainda, a criar mecanismos que, em conjunto com os Estados, possam promover a aplicação dos princípios enunciados na Declaração para a proteção dos dados genéticos do homem.

O preâmbulo da Declaração insere-na no sistema internacional de proteção dos direitos humanos e do genoma humano, fazendo referência aos principais documentos publicados nesse âmbito. Contudo, menção especial é feita à Declaração Universal sobre o Genoma Humano e os Direitos Humanos de 1997 e suas resoluções complementares de 1999, por constituir elemento inspirador à proclamação da Declaração para a proteção dos dados genéticos. Reconhece a crescente importância dos dados genéticos humanos em âmbito comercial e econômico, bem como sua especificidade: fatores que impõem

\footnotetext{
${ }^{291}$ Prefácio à Declaração Internacional sobre os Dados Genéticos Humanos. Disponível no site da Unesco: www. unesco.org.br.

292 Prefácio à Declaração Internacional sobre os Dados Genéticos Humanos. Disponível no site da Unesco: www. unesco.org.br.
} 
tratamento diferenciado e a mais ampla confidencialidade, independentemente de seu conteúdo. Propõe, ainda, o reforço da cooperação internacional no domínio da genética humana e a maximização dos princípios da proteção da vida privada, da segurança das pessoas e da liberdade de investigação.

O artigo $1^{\mathrm{o}}$ define os objetivos e o âmbito de aplicação da Declaração. Os objetivos seriam garantir o respeito da dignidade humana e a proteção dos direitos humanos e das liberdades fundamentais no recolhimento, tratamento, utilização e conservação dos dados genéticos humanos, os quais devem ser processados em conformidade com o direito internacional relativo aos direitos humanos. O âmbito de aplicação diz respeito, exatamente às ações de recolhimento, tratamento, utilização e conservação de dados genéticos, bem como aos casos de utilização desses dados em procedimentos judiciais.

$\mathrm{O}$ artigo $2^{\circ}$ define o que se entende por alguns termos e expressões utilizados na Declaração, destacando os bens jurídicos protegidos pelo documento ora em comento.

- Dados genéticos humanos são informações relativas às características hereditárias dos indivíduos, obtidas pela análise de ácidos nucleicos ou por outras análises científicas;

- Dados proteómicos humanos são informações relativas às proteínas de um indivíduo, incluindo a sua expressão, modificação e interacção;

- $\quad$ Amostra biológica é qualquer amostra de material biológico (por exemplo células do sangue, da pele e dos ossos ou plasma sanguíneo) em que estejam presentes ácidos nucleicos e que contenha a constituição genética característica de um indivíduo.

$\mathrm{O}$ artigo $3^{\circ}$ afirma que os dados genéticos humanos integram o conteúdo da identidade pessoal de cada ser-humano. É de se ver, contudo, que a identidade humana não se reduz a tais dados, porquanto nela intervêem outros fatores ambientais, sociais, educativos e culturais, que participam da construção da identidade de cada pessoa.

Primacial importância deve ser concedida ao $4^{\circ}$ da Declaração, porquanto ele estabelece a natureza especial dos dados genéticos humanos, ao argumento de que: i) 
sejam preditivas as disposições genéticas dos indivíduos; ii) podem ter um impacto significativo sobre a família, incluindo a descendência, ao longo de várias gerações, e em certos casos sobre todo o grupo a que pertence a pessoa em causa; iii) podem conter informações cuja importância não é necessariamente conhecida no momento em que são recolhidas as amostras biológicas; e iv) podem revestir-se de importância cultural para pessoas ou grupos. Dessa especialidade decorreria a necessidade de concessão de maior atenção ao tratamento dos dados genéticos das amostras biológicas que os contenham, os quais poderiam ser utilizados para os fins elencados no artigo $5^{\circ}$, que ora transcrevemos:

(i) diagnóstico e cuidados de saúde, incluindo os rastreios e os testes preditivos;

(ii) investigação médica e outra investigação científica, incluindo os estudos epidemiológicos, em particular os estudos de genética das populações, assim como os estudos antropológicos ou arqueológicos, daqui em diante designados colectivamente pela expressão «investigação médica e científica»;

(iii) medicina legal e processos civis ou penais e outros procedimentos legais,

(iv) ou qualquer outro fim compatível com a Declaração Universal sobre o Genoma Humano e os Direitos Humanos e com o direito internacional relativo aos direitos humanos.

A questão dos procedimentos a serem adotados para o recolhimento, tratamento, utilização e conservação dos dados genéticos e proteómicos humanos é tratada no artigo $6^{\circ}$. Tal dispositivo consagra o princípio da transparência, do consentimento livre e informado $^{293}$ e da ampla participação da sociedade na discussão de questões éticas suscitadas por estes procedimentos.

Nesse sentido, a criação de comitês de ética independentes, pluridisciplinares e pluralistas, ganha importância e deve ser promovida. Igualmente, a

\footnotetext{
${ }^{293}$ No tocante ao consentimento livre e informado, transcrevemos parte do artigo $6^{\circ}$ da Declaração, o qual aborda pormenorizadamente o tema: "Do ponto de vista ético, é imperativo que sejam fornecidas informações claras, objectivas, adequadas e apropriada à pessoa a quem é solicitado consentimento prévio, livre, informado e expresso. Estas informações, além de fornecerem outros pormenores necessários, especificam as finalidades para as quais serão obtidos, utilizados e conservados os dados genéticos humanos e dados proteómicos da análise das amostras biológicas. Estas informações deverão, se necessário, indicar os riscos e consequências em causa. Deverão igualmente indicar que a pessoa poderá retirar o seu consentimento sem
} 
Declaração ora em referência considera essencial a existência de comitês nacionais de ética em pesquisas, que sejam capazes de regulamentar e estabelecer diretivas em nível nacional e possibilitar a consulta por pesquisadores e médicos nos casos em que não houver legislação interna específica sobre determinado tema relacionado à proteção dos dados genéticos humanos. No caso de procedimentos que tenham lugar em mais de um Estado, a Declaração determina que sejam consultados os comitês nacionais de ética dos Estados envolvidos, os quais considerarão, em suas decisões, os princípios ora enunciados.

$\mathrm{O}$ artigo $7^{\circ}$ afirma o princípio da não-discriminação e não estigmatização, determinando que sejam empenhados todos os esforços no sentido de impedir que dados genéticos e dados proteómicos sejam utilizados para fins discriminatórios ou de estigmatização de indivíduos, de uma família, grupo de pessoas ou comunidade.

$\mathrm{O}$ artigo $8^{\circ}$ destaca, especificamente, o princípio do consentimento, o qual é definido no artigo $2^{\circ}$ como sendo "qualquer acordo específico, expresso e informado dado livremente por um indivíduo para que os seus dados genéticos sejam recolhidos, tratados, utilizados e conservados". Ele é necessário para que se proceda a qualquer recolhimento de dados genéticos humanos, dados proteómicos ou amostras biológicas, e para que se decida o que fazer com as informações coletadas e processadas. Qualquer restrição a este princípio deve, necessariamente, fundar-se na proteção de outros princípios definidores de direitos humanos que com este colidam. No caso de pessoas que sejam consideradas incapazes para consentir, o artigo $8^{\circ}$ determina que tal consentimento seja suprido através de autorização do seu representante legal, de acordo com as regras de representação de cada país. De qualquer forma, a opinião do incapaz deve ser, em certa medida, considerada na decisão a ser tomada. Sublinhamos, ademais, que o item $d$ do artigo $9^{\circ}$ estabelece que a realização de testes genéticos em incapazes somente será aceitável quando tenham importantes implicações para a saúde da pessoa - não sendo admitidos, portanto, para fins exclusivos de pesquisa e formação de bancos de dados.

De fato, o artigo $9^{\circ}$ complementa a redação do artigo $8^{\circ}$, pois aborda o tema da retirada do consentimento anteriormente manifestado. Ela é possível, sem que resulte em

coerção e que daí não deverá resultar para ela qualquer desvantagem ou penalidade”. Disponível no site da 
qualquer penalidade ou desvantagem para a pessoa envolvida, sempre que os dados em questão não tenham sido irreversivelmente dissociados de uma pessoa identificável. Demais disso, ocorrendo a revogação do consentimento anteriormente concedido, os dados coletados não poderão ser reutilizados e deverão ser tratados de acordo com os desejos da pessoa em causa. Todavia, conforme bem define o dispositivo ora em comento, "se tais desejos não puderem ser determinados ou forem irrealizáveis ou perigosos, os dados e as amostras biológicas deverão ser irreversivelmente dissociados ou destruídos".

$\mathrm{O}$ artigo $10^{\circ}$ prevê o direito a decidir ser ou não informado dos resultados da investigação. Destarte, no momento do fornecimento das informações necessárias para a manifestação do consentimento pessoal, deve-se dar ciência ao sujeito da existência do direito a não ser informado, se quiser, dos resultados das pesquisas. Segundo a Declaração "esta cláusula não se aplica à investigação sobre dados irreversivelmente dissociados de pessoas identificáveis nem a dados que não conduzam a conclusões individuais relativas às pessoas que participaram na referida investigação", mas é extensível aos familiares que possam ser afetados pelos resultados.

O artigo 11 impõe o aconselhamento genético ${ }^{294}$, considerando-o um imperativo ético para os casos de resultados de testes genéticos que possam ter implicações para a saúde da pessoa e de seus descendentes. Importante, contudo, destacar a noção trazida pela Unesco de que tal aconselhamento, além de fundar-se na proteção dos interesses do aconselhado, deve ser culturalmente adaptado ao contexto social em que se insere.

O tema relativo ao recolhimento de amostras biológicas para fins de medicina legal ou de processos civis ou penais é abordado no artigo 12, o qual determina que tal procedimento deverá observar as regras e princípios previstos no direito interno e internacional. Ressaltem-se, então, a título exemplificativo, os princípios do contraditório, do devido processo legal e a vedação de provas ilícitas.

Unesco: www.unesco.org.br.

${ }^{294} \mathrm{O}$ aconselhamento genético é definido no artigo $2^{\circ}$ da Declaração como sendo "procedimento que consiste em explicar as consequências possíveis dos resultados de um teste ou de um rastreio genético, suas vantagens e seus riscos e, se for caso disso, ajudar o indivíduo a assumir essas consequências a longo prazo. O aconselhamento genético tem lugar antes e depois do teste ou do rastreio genético". 
O artigo 13 ressalta o princípio do livre acesso de cada pessoa aos seus próprios dados genéticos ou dados proteómicos. Estabelece, porém, algumas possibilidades de restrição ao gozo do direito advindo desse princípio: quando os dados forem irreversivelmente dissociados da pessoa que seria sua fonte identificável ou no caso de interesse da saúde pública, da ordem pública ou da segurança nacional. Importante anotar, nesse sentido, que as possibilidades de restrição ao princípio do livre-acesso são bastante genéricas e poderiam ser interpretadas de modo a justificar a coleta de dados genéticos para fins não divulgados e eventualmente eugenéticos.

$\mathrm{O}$ artigo 14 trata da confidencialidade dos dados genéticos, definindo sua proteção como sendo uma obrigação para os Estados. Decorre da enunciação do referido princípio a vedação de que os dados associados a pessoa identificável sejam tornados acessíveis a terceiros, especialmente a empregadores, companhias de seguro e estabelecimentos de ensino. Restrição a tal direito pode ser definida pelo interesse público, desde que em conformidade com as normas internas do Estado e aquelas definidoras de direitos humanos no âmbito internacional e, ainda, sob reserva "de consentimento prévio, livre, informado e expresso da pessoa em causa". Ademais, o artigo 15 complementa o princípio da confidencialidade ao estabelecer que as pessoas e entidades encarregadas do tratamento de dados genéticos humanos, dados proteómicos e amostras biológicas devem tomar todas as medidas necessárias para garantir a exatidão, confiabilidade e segurança desses dados. Para tanto, deverão demonstrar rigor, prudência, honestidade e integridade no seu tratamento, sempre considerando suas implicações éticas e legais.

O artigo 16 insere-se no capítulo sobre a utilização dos dados genéticos e proteómicos humanos e amostras biológicas. Afirma que eles não deverão ser utilizados para finalidade diferente daquela para a qual foi dado o consentimento prévio pela pessoa em causa, salvo em caso de relevante interesse público e desde que em conformidade com os dispositivos de proteção dos direitos humanos na esfera internacional. Por outro lado, prevê o artigo $8^{\circ}$ que nos casos em que não for possível a manifestação do consentimento ou em situações em que os dados genéticos estejam irreversivelmente dissociados de uma pessoa identificável, será possível sua utilização, desde que se atue de acordo com os procedimentos de consulta aos comitês nacionais de ética previstos no art. $6^{\circ}$ da Declaração 
em tela. Analogicamente, o artigo 17 dispõe que a conservação das amostras biológicas deve respeitar o "consentimento prévio, livre, informado e expresso da pessoa envolvida". Contudo, no caso de relevante interesse científico, define, igualmente, a Declaração a possibilidade de restrição de tal exigência, desde que fundada em decisão tomada pelos comitês nacionais de ética, com base no procedimento preconizado no art. $6^{\circ}$.

A cooperação internacional para divulgação dos dados genéticos e proteómicos humanos, de modo a fomentar o acesso eqüitativo a esses dados pelos Estados e pesquisadores, é ressaltada no artigo 18. Cuida-se de proclamação do princípio da solidariedade no âmbito de proteção dos dados genéticos humanos, visando, claramente, a favorecer a cooperação científica interestatal, especialmente entre países industrializados e aqueles em desenvolvimento. Com efeito, os benefícios advindos das pesquisas que utilizam dados genéticos e proteómicos humanos e amostras biológicas deverão ser partilhados com a sociedade como um todo, o que inclui a comunidade internacional. Nesse sentido, reconhecendo o genoma humano como patrimônio de cada um e da humanidade, o artigo 19 estabelece o princípio da partilha dos benefícios - os quais poderão assumir as seguintes formas:

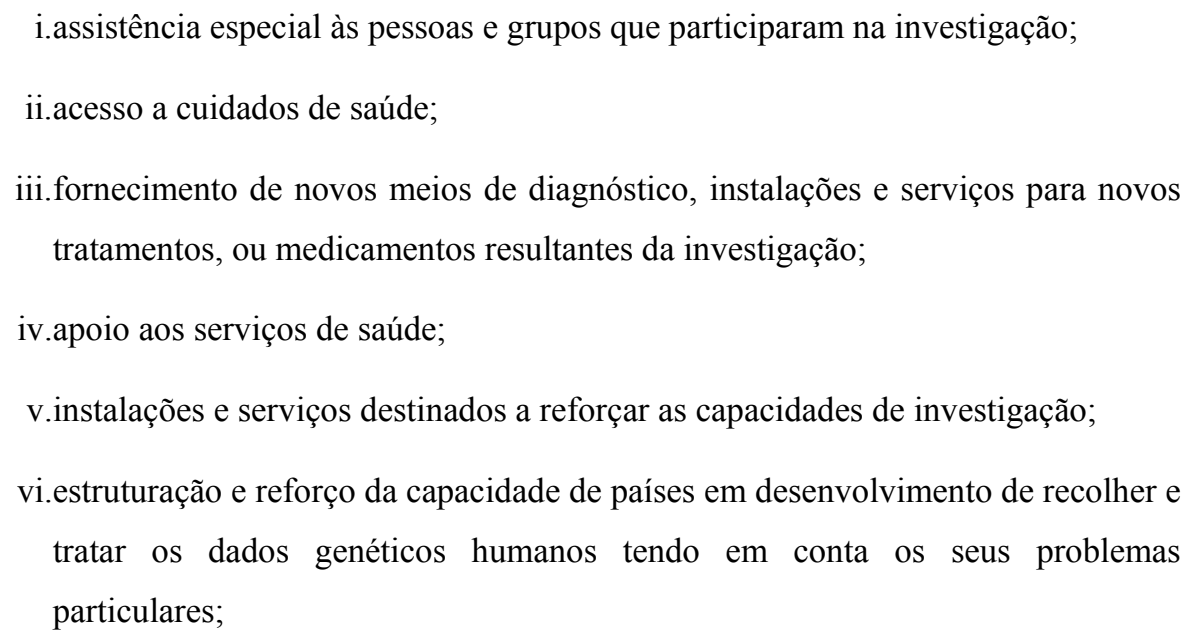
Declaração.

O artigo 20 é entitulado "dispositivo de supervisão e gestão" e insere-se no capítulo destinado às questões envolvidas na conservação dos dados genéticos. Define, claramente, a natureza aberta da Declaração, pois prevê a possibilidade dos Estados 
instituírem dispositivo de supervisão e gestão, sempre com base nos princípios da independência, multidisciplinariedade, pluralismo e transparência. Em perspectiva diversa, o artigo 21, trata da destruição dos dados genéticos, afirmando-a como regra geral para os casos de dados genéticos utilizados em processo judicial, prescrevendo sua inutilização logo que deixem de ser necessários, salvo se o direito interno dispuser de modo diverso e se tal determinação não colidir com as normas de direitos humanos proclamadas no âmbito internacional.

$\mathrm{O}$ artigo 22 define exigência especial para a regra geral do consentimento. Afirma ser indispensável o consentimento para qualquer cruzamento de dados genéticos para fins de diagnóstico e cuidados de saúde e também para fins de investigação médica e científica. A esta regra, contudo, é possível que o direito interno dos Estados estabeleça ressalva, desde que esta respeite os princípios e regras de direitos humanos.

O artigo 23 trata da aplicação dos princípios definidos na Declaração ora em referência. Afirma ser necessário que os Estados adotem todas as medidas suficientes, de caráter legislativo ou administrativo, para que os princípios enunciados sejam efetivados. Além disso, todas as ações promovidas devem ser amparadas por iniciativas em matéria de educação, formação e informação da sociedade sobre a importância de cada um dos princípios proclamados. Ainda no âmbito da aplicação, os Estados deverão fomentar a cooperação internacional para que os países em desenvolvimento possam, através de acordos bilaterais e multilaterais, participar do intercâmbio de conhecimentos sobre os dados genéticos humanos.

Ainda no capítulo destinado à promoção e aplicação da Declaração situa-se, outrossim, o artigo 24, que determina que os Estados deverão fomentar a educação e formação no domínio da ética dos membros dos comitês de ética, dos investigadores científicos e da população em geral. Nessa empreitada, “os Estados deverão estimular as organizações intergovernamentais internacionais e regionais, bem como as organizações não-governamentais internacionais, regionais e nacionais a que participem nesta tarefa". No mesmo sentido, o artigo 25 prevê a criação do Comitê Internacional de Bioética (CIB) e do Comitê Intergovernamental de Bioética (CIGB), propugnando que suas funções precípuas seriam a contribuição para a aplicação efetiva da Declaração e a difusão dos princípios nela 
enunciados. Deverão, portanto, acompanhar a implementação do documento ora em comento pelos Estados e formular pareceres e propostas para a maximização de sua efetivação, além de possuírem competência para a proposição de recomendações à Conferência Geral da Unesco.

A Unesco reafirma, finalmente, no artigo 26, seu compromisso em acompanhar a implementação da presente Declaração e fomentar o avanço das ciências da vida e tecnologias correlatas com base no respeito pela dignidade da pessoa humana e pelos direitos humanos. Dessarte, assim como na Declaração sobre o Genoma Humano e Direitos Humanos e na Declaração Universal de Bioética e Direitos Humanos, a Unesco inseriu dispositivo que veda a interpretação de qualquer artigo desta Declaração de modo a justificar atos contrários aos direitos humanos, à dignidade da pessoa humana e aos próprios princípios nela declarados. Trata-se de enunciado hermenêutico que ratifica a inserção desse documento no sistema internacional de proteção dos direitos humanos.

\section{O substrato legal de protecão no âmbito do ordenamento jurídico}

$\underline{\text { brasileiro. }}$

Inicialmente, destacamos que a legislação brasileira sobre bioética ainda é incipiente. No entanto, em razão da explícita previsão constitucional de proteção da dignidade da pessoa humana, é certo que os temas de bioética devem ser analisados à luz dos princípios definidores de direitos fundamentais na ordem interna e dos direitos estabelecidos no sistema internacional de proteção dos direitos humanos.

\subsection{Constituição Federal}

$\mathrm{O}$ artigo $1^{\mathrm{o}}$, inciso III, da Constituição Federal expressamente afirma o valor da dignidade da pessoa humana, o qual constitui princípio estruturante do Estado Democrático de Direito brasileiro, com conteúdo preenchido pelos direitos considerados mais fundamentais ao homem, reconhecidos pela Constituição ou supranacionalmente. 
Funciona, portanto, como referencial hermenêutico para a formulação e interpretação de normas que regulem a aplicação das técnicas de engenharia genética.

O conteúdo do princípio estruturante da dignidade humana encontra-se parcialmente materialmente preenchido pelo rol de princípios definidores de direitos fundamentais contido no artigo $5^{\circ}$ da Constituição Federal, os quais definem parte da tábua axiológica de princípios considerados fundamentais ao pleno desenvolvimento de cada ser-humano pelo Estado brasileiro. São complementados, contudo, por princípios de proteação dos direitos humanos definidos no âmbito internacional e por princípios materialmente contitucionais, que embora não expressamente proclamados pelo constituinte originário, consubstanciam verdadeiros princípios informadores do núcleo axiológico da dignidade humana. Ressalte-se, nesse sentido, os princípios da autonomia, beneficência, não maleficência, justiça, vulnerabilidade, integridade e responsabilidade, já devidamente expostos ao longo do presente trabalho.

Expressamente, a Constituição Federal de 1988 proclama o direito à vida, previsto no caput do art. $5^{\circ}$ da Carta magna brasileira, bem como o direito à liberdade, em suas múltiplas dimensões, dentre as quais é de se sublinhar, em razão de sua aplicabilidade às situações conflituosas emergentes com as técnicas de engenharia genética, a liberdade de expressão da atividade científica ${ }^{295}$ - que possui previsão, específica, no inciso IX do art. $5^{\circ}$ - e o direito de autonomia do paciente e do sujeito de pesquisa - que decorre do princípio geral de liberdade previsto no caput do artigo $5^{\circ}$ da Constituição Federal.

Ademais, é de se salientar o princípio definidor do direito à igualdade, igualmente previsto no caput do art. $5^{\circ}$, do qual deriva a vedação de discriminações por motivos genéticos, sejam elas perpetradas pelo Estado ou por particulares. No mesmo sentido, o inciso XLI do referido artigo $5^{\circ}$ afirma que "a lei punirá qualquer discriminação atentatória dos direitos e liberdades fundamentais", prescrevendo o dever ao legislador

${ }^{295} C f$. Inciso IX do art. $5^{\circ}$ da CF: "É livre a expressão da atividade intelectual, artística, científica e de comunicação, independentemente de censura e licença”. 
ordinário, de regular os casos de discriminação. Registramos, contudo, que, ainda que inexistente lei infraconstitucional dirigida, diretamente, à vedação da discriminação genética, não restam dúvidas de que o sistema interno e internacional de proteção dos direitos humanos, expressamente, protege a pessoa humana contra qualquer tipo de discriminação ilegítima e arbitrária, conforme, inclusive, se vê das disposições contidas nas declarações de direitos humanos da Unesco, amplamente comentadas neste trabalho.

No que concerne ao tema da confidencialidade das informações genéticas, é de se destacar que $\mathrm{o}$ inciso $\mathrm{X}$ da Constituição Federal expressamente define serem invioláveis "a intimidade, a vida privada, a honra e a imagem das pessoas, assegurando o direito a indenização pelo dano material ou moral decorrente de sua violação". Destarte, repise-se, ainda que o Brasil não possua legislação específica para a proteção de dados genéticos pessoais, a Constituição Federal constitui arcabouço jurídico suficiente para se afirmar que tais dados devam ser protegidos, até porque, tendo sido o direito à intimidade erigido à categoria de direito fundamental, participa do núcleo axiológico da noção de dignidade da pessoa humana.

Ademais, cumpre dar relevo ao dever do Estado de promover e incentivar o desenvolvimento científico, a pesquisa e a capacitação científica, conforme constante no artigo 218 da Constituição Federal ${ }^{296}$. Tal dispositivo encontra-se inserido no capítulo IV do título concernente à ordem social, o qual se destina ao tratamento da ciência e da tecnologia. Estabelece diretrizes para a ação fomentadora do Estado, que deve viabilizar o

\footnotetext{
296 “Art. 218. O Estado promoverá e incentivará o desenvolvimento científico, a pesquisa e a capacitação tecnológicas.

$\S 1^{\circ}$ - A pesquisa científica básica receberá tratamento prioritário do Estado, tendo em vista o bem público e o progresso das ciências.

$\S 2^{\circ}$ - A pesquisa tecnológica voltar-se-á preponderantemente para a solução dos problemas brasileiros e para o desenvolvimento do sistema produtivo nacional e regional.

$\S 3^{\circ}$ - O Estado apoiará a formação de recursos humanos nas áreas de ciência, pesquisa e tecnologia, e concederá aos que delas se ocupem meios e condições especiais de trabalho.

$\S 4^{\circ}$ - A lei apoiará e estimulará as empresas que invistam em pesquisa, criação de tecnologia adequada ao País, formação e aperfeiçoamento de seus recursos humanos e que pratiquem sistemas de remuneração que assegurem ao empregado, desvinculada do salário, participação nos ganhos econômicos resultantes da produtividade de seu trabalho.

$\S 5^{\circ}$ - É facultado aos Estados e ao Distrito Federal vincular parcela de sua receita orçamentária a entidades públicas de fomento ao ensino e à pesquisa científica e tecnológica".
} 
pleno desenvolvimento de técnicas inovadoras por parte dos pesquisadores brasileiros apoiando a formação de recursos humanos nas áreas de ciência, pesquisa e tecnologia, e concedendo aos que delas se ocupem meios e condições especiais de trabalho. Contudo, é certo que tal princípio, relacionado ao fomento da ciência, não é absoluto, podendo, claramente, ser restringido, quando colidir com os demais princípios fundamentais ao desenvolvimento pleno da pessoa humana.

Cumpre, ainda, destacar a previsão contida no artigo 225 da Carta Magna ${ }^{297}$, a qual estabelece, em seu inciso II, incumbir ao Estado promover a diversidade e a integridade do patrimônio genético no país e fiscalizar as entidades dedicadas à pesquisa e à manipulação de material genético. E, embora este dispositivo tenha sido inserido em capítulo dedicado ao meio-ambiente, não restam dúvidas de que também se aplica à defesa do patrimônio genético humano, segundo entendimento de que o homem participa do meio-

297 “Art. 225. Todos têm direito ao meio ambiente ecologicamente equilibrado, bem de uso comum do povo e essencial à sadia qualidade de vida, impondo-se ao Poder Público e à coletividade o dever de defendê-lo e preservá- lo para as presentes e futuras gerações.

$\S 1^{\circ}$ - Para assegurar a efetividade desse direito, incumbe ao Poder Público:

I - preservar e restaurar os processos ecológicos essenciais e prover o manejo ecológico das espécies e ecossistemas;

II - preservar a diversidade e a integridade do patrimônio genético do País e fiscalizar as entidades dedicadas à pesquisa e manipulação de material genético;

III - definir, em todas as unidades da Federação, espaços territoriais e seus componentes a serem especialmente protegidos, sendo a alteração e a supressão permitidas somente através de lei, vedada qualquer utilização que comprometa a integridade dos atributos que justifiquem sua proteção;

IV - exigir, na forma da lei, para instalação de obra ou atividade potencialmente causadora de significativa degradação do meio ambiente, estudo prévio de impacto ambiental, a que se dará publicidade;

V - controlar a produção, a comercialização e o emprego de técnicas, métodos e substâncias que comportem risco para a vida, a qualidade de vida e o meio ambiente;

VI - promover a educação ambiental em todos os níveis de ensino e a conscientização pública para a preservação do meio ambiente;

VII - proteger a fauna e a flora, vedadas, na forma da lei, as práticas que coloquem em risco sua função ecológica, provoquem a extinção de espécies ou submetam os animais a crueldade.

$\S 2^{\circ}$ - Aquele que explorar recursos minerais fica obrigado a recuperar o meio ambiente degradado, de acordo com solução técnica exigida pelo órgão público competente, na forma da lei.

$\S 3^{\circ}$ - As condutas e atividades consideradas lesivas ao meio ambiente sujeitarão os infratores, pessoas físicas ou jurídicas, a sanções penais e administrativas, independentemente da obrigação de reparar os danos causados.

$\S 4^{\circ}$ - A Floresta Amazônica brasileira, a Mata Atlântica, a Serra do Mar, o Pantanal Mato-Grossense e a Zona Costeira são patrimônio nacional, e sua utilização far-se-á, na forma da lei, dentro de condições que assegurem a preservação do meio ambiente, inclusive quanto ao uso dos recursos naturais.

$\S 5^{\circ}$ - São indisponíveis as terras devolutas ou arrecadadas pelos Estados, por ações discriminatórias, necessárias à proteção dos ecossistemas naturais.

$\S 6^{\circ}$ - As usinas que operem com reator nuclear deverão ter sua localização definida em lei federal, sem o que não poderão ser instaladas". 
ambiente $^{298}$. Ou seja, o legislador constitucional atribui ao poder público tanto a obrigação de preservar a diversidade e a integridade do patrimônio genético dos seres vivos existentes no território nacional quanto o dever de fomentar e viabilizar o desenvolvimento científico - deixando, portanto, clara a idéia de complementaridade que deve nortear a aplicação desses dois princípios.

\subsection{Legislação infraconstitucional.}

No plano infraconstitucional merece destaque a Lei $n{ }^{\circ} 8.974$, de janeiro de 1995, regulamentada pelo Decreto $\mathrm{n}^{\circ} 1.752$, de dezembro de 1995, porquanto, pela primeira vez na legislação brasileira, delimitou o conceito de engenharia genética (artigo $3^{\circ}$, incisos IV e $\mathrm{V}^{299}$ ) e abordou temas diretamente relacionados a ela. A referida lei foi revogada pela Lei $\mathrm{n}^{\circ} 11.105$, de 24 de março de 2005, ora em vigor, regulamentada pelo Decreto $\mathrm{n}^{\mathrm{o}} 5.591$, também de 2005, os quais serão abordados a seguir.

\subsubsection{Lei $\mathrm{n}^{0} 11.105$ de 24 de marco de 2005 - Lei de Biosseguranca.}

A Lei $\mathrm{n}^{\mathrm{o}} 11.105$ de 2005, conhecida como Lei de Biossegurança brasileira, enfrentou, primacialmente, três temas abordados pela bioética: a clonagem, a utilização de células-tronco embrionárias e o desenvolvimento, produção e comercialização de organismos geneticamente modificados. Revogou a Lei 8.974, de 05 de janeiro de 1995, e a Medida Provisória n ${ }^{\circ}$ 2.191-9, de 23 de agosto de 2001 e, na esteira da lei anterior, restou por misturar duas demandas diferentes: a dos produtores agro-pecuários, que pleiteavam a liberação dos transgênicos e que tinham contra eles os ambientalistas, e a dos cientistas, que lutavam pela permissão de pesquisas em células-tronco embrionárias. Assim, embora se possa afirmar que a lei em referência previu dispositivos de proteção do patrimônio genético humanos, fê-lo de forma genérica, prestando muito mais atenção à questão dos organismos geneticamente modificados.

\footnotetext{
${ }^{298}$ Cf. Entrevista a Marcos Pivetta e Mariluce Moura. In:Revista Pesquisa, n. 110 , abril de 2005, p. 12 e ss.

${ }^{299}$ Art. $3^{\circ}$ da Lei 8.974/1995: “ IV - Organismo geneticamente modificado (OGM) - Organismo cujo material genético (ADN/ARN) tenha sido modificado por qualquer técnica de engenharia genética. V - Engenharia genética - Atividade de manipulação de moléculas de ADN/ARN recombinante".
} 
Definiu, contudo, as noções de engenharia genética, célula germinal humana, clonagem e células-tronco embrionárias - relevantes para a interpretação dos dispositivos reguladores de tais atividades no direito brasileiro. In verbis:

“Art. 3ํㅡㄹ Para os efeitos desta Lei, considera-se: [...]

IV - engenharia genética: atividade de produção e manipulação de moléculas de ADN/ARN recombinante;

VII - célula germinal humana: célula-mãe responsável pela formação de gametas presentes nas glândulas sexuais femininas e masculinas e suas descendentes diretas em qualquer grau de ploidia;

VIII - clonagem: processo de reprodução assexuada, produzida artificialmente, baseada em um único patrimônio genético, com ou sem utilização de técnicas de engenharia genética;

IX - clonagem para fins reprodutivos: clonagem com a finalidade de obtenção de um indivíduo;

X - clonagem terapêutica: clonagem com a finalidade de produção de células-tronco embrionárias para utilização terapêutica;

XI - células-tronco embrionárias: células de embrião que apresentam a capacidade de se transformar em células de qualquer tecido de um organismo".

Em seu artigo $5^{\circ}$, a lei permite a utilização de células-tronco embrionárias obtidas de embriões humanos produzidos por fertilização "in vitro", para os fins de pesquisa e terapia. Impõe, para tanto, porém, o respeito a certos requisitos: que o embrião seja considerado inviável (supostamente incapaz de gerar uma vida) ou o congelamento por no mínimo três anos - além da aquiescência dos genitores e aprovação do comitê de ética em pesquisa responsável ${ }^{300}$. A constitucionalidade deste dispositivo legal foi questionada

\footnotetext{
300 “Art. 5ํ́ É permitida, para fins de pesquisa e terapia, a utilização de células-tronco embrionárias obtidas de embriões humanos produzidos por fertilização in vitro e não utilizados no respectivo procedimento, atendidas as seguintes condições:

I - sejam embriões inviáveis; ou

II - sejam embriões congelados há 3 (três) anos ou mais, na data da publicação desta Lei, ou que, já congelados na data da publicação desta Lei, depois de completarem 3 (três) anos, contados a partir da data de congelamento.
}

$\S 1^{\circ}$ Em qualquer caso, é necessário o consentimento dos genitores. 
perante o pretório Excelso, em razão da propositura da ADI no 3510 pelo Procurador-Geral da República, ao fundamento de que a permissão de pesquisas que utilizem células-tronco atentaria contra o direito à vida, previsto na Constituição Federal. Julgada improcedente a referida Ação Direta de Inconstitucionalidade, a lei de Biossegurança brasileira permanece em pleno vigor.

Sem adentrarmos no debate ético envolvido na utilização de células-tronco embrionárias, cumpre destacar que a lei, ao permitir o uso de embriões humanos para pesquisa no caso de inviabilidade para a vida, não definiu critérios para a aferição dessa inviabilidade - deixando tal definição para regulamentação por meio de decreto ${ }^{301}$. Ademais, a lei foi completamente omissa no que concerne à diferenciação entre célulastronco adultas e as células-tronco do cordão umbilical, do que se depreende ser possível a utilização das últimas. De outra sorte, no que concerne à possibilidade de descarte de embriões, embora a lei em comento não tenha tratado rigorosamente da matéria, autoriza-o quando inviáveis e quando congelados há três ou mais anos - tendo, portanto, afastado qualquer imputação criminosa ao descarte feito sob tais condições.

Ao tema desse trabalho, é de rigor destacar que o artigo $6^{\circ}$ da Lei ${ }^{\circ}$ $11.105 / 2005$ proibiu a prática de engenharia genética em células germinais ${ }^{302}$ - que são as células reprodutivas -, o que teve como principal objetivo prevenir a alteração de características genéticas individuais, fato que poderia refletir em toda a descendência da pessoa. Vedou, ainda, de forma genérica, a clonagem ${ }^{303}$, sem que, todavia, tenha procedido

$\S 2^{\underline{0}}$ Instituições de pesquisa e serviços de saúde que realizem pesquisa ou terapia com células-tronco embrionárias humanas deverão submeter seus projetos à apreciação e aprovação dos respectivos comitês de ética em pesquisa.

$\S 3^{0}$ É vedada a comercialização do material biológico a que se refere este artigo e sua prática implica o crime tipificado no art. 15 da Lei $n^{\circ}$ 9.434, de 4 de fevereiro de 1997”.

${ }^{301}$ Acrescentamos que a lei proíbe o comércio de embriões, classificando a transgressão como crime (parágrafo $3^{\circ}$ do artigo $5^{\circ}$ ).

${ }^{302} C f$. Art. $6^{\circ}$ da Lei 11.105/2005. "Fica proibido:

$[\ldots]$

III - engenharia genética em célula germinal humana, zigoto humano e embrião humano;

IV - clonagem humana".

${ }^{303}$ No que concerne ao dispositivo legal que proíbe a clonagem humana anotamos que no mundo inteiro tal vedação encontra-se contida na legislação sobre reprodução assistida e não naquela afeta a questões de biossegurança. 
a qualquer ressalva quanto à clonagem terapêutica, que poderia ser útil na prevenção de doenças como o mal de Alzheimer e diabetes.

É de se sublinhar, ainda, que, além das proibições contidas no artigo $6^{\circ}$ da lei - ora citadas -, que poderiam ensejar a aplicação de penalidades administrativas pelo seu descumprimento, o legislador criminalizou tais condutas nos artigos 24, 25 e 26 da Lei $^{304}$ - dentre as quais também se inclui a que se refere à utilização de embrião humano em desacordo com o que dispõe o artigo $5^{\circ}$. Da análise dos dispositivos criminais, encontramos o que consideramos a maior lacuna do referido diploma legal: ao criminalizar a clonagem de modo genérico, não deixou claro se, igualmente, incluiu nessa conduta a clonagem para fins terapêuticos, como, por exemplo, a clonagem de células-tronco adultas da própria pessoa para uso da medicina regenerativa. Gerou-se, então, um paradoxo lógico, pois a lei permitiu o uso de células-tronco embrionárias, mas não permitiu a clonagem terapêutica.

E, além da criminalização de certas condutas, a referida Lei estabeleceu, ainda, no artigo $20^{305}$, a responsabilidade objetiva daqueles que venham a causar danos ao meio-ambiente e a terceiros, e das entidades públicas ou privadas, inclusive internacionais, que venham a financiar ou patrocinar atividades e projetos envolvendo organismos geneticamente modificados sem o Certificado de Qualidade em Biossegurança necessário. Todavia, cumpre-nos consignar que referida noção de responsabilidade objetiva não é aplicável aos casos de descumprimento das proibições referentes à utilização de embriões humanos, à prática de engenharia genética em célula germinal humana e à clonagem humana - conforme se conclui da leitura do artigo ora em análise -, salvo para apuração de danos eventualmente causados a terceiros.

\footnotetext{
304 “'Art. 24. Utilizar embrião humano em desacordo com o que dispõe o art. 5ำ desta Lei:

Pena - detenção, de 1 (um) a 3 (três) anos, e multa.

Art. 25. Praticar engenharia genética em célula germinal humana, zigoto humano ou embrião humano:

Pena - reclusão, de 1 (um) a 4 (quatro) anos, e multa.

Art. 26. Realizar clonagem humana:

Pena - reclusão, de 2 (dois) a 5 (cinco) anos, e multa".

305 Art. 20 da Lei 11.105/2005: "Sem prejuízo da aplicação das penas previstas nesta Lei, os responsáveis pelos danos ao meio ambiente e a terceiros responderão, solidariamente, por sua indenização ou reparação integral, independentemente da existência de culpa".
} 


\subsubsection{Decreto $\mathrm{n}^{0} 5.591$ de 22 de novembro de 2005 .}

O Decreto $\mathrm{n}^{\mathrm{o}} 5.579$, de 22 de novembro de 2005, regulamentou alguns dispositivos da Lei $n^{0}$ 11.105/2005 - o que afirma sua relevância ao estudo da proteção da pessoa humana face às eventuais ofensas suscitadas pelas técnicas de engenharia genética. Buscou, especialmente, suprir omissões contidas na lei federal, precisando o sentido de certas proibições que haviam sido enunciadas. Nesse contexto, insere-se a definição do que seriam embriões inviáveis, que restou por suprir lacuna da Lei n. 11.105/2005, a qual, reitere-se, permitiu a utilização de células-tronco embrionárias obtidas de embriões humanos produzidos por fertilização "in vitro", quando esses fossem considerados inviáveis, sem, contudo, estabeler o conceito de viabilidade. Com fundamento no Decreto ora em tela, são embriões inviáveis "aqueles com alterações genéticas comprovadas por diagnóstico pré implantacional, conforme normas específicas estabelecidas pelo Ministério da Saúde, que tiveram seu desenvolvimento interrompido por ausência espontânea de clivagem após período superior a vinte e quatro horas a partir da fertilização in vitro, ou com alterações morfológicas que comprometam o pleno desenvolvimento do embrião”. 


\section{Conclusões:}

A noção de dignidade da pessoa humana como critério legitimador do poder estatal e princípio estruturante e hermenêutico de toda a ordem jurídica de Estados Democráticos de Direito esteve no centro desse trabalho.

Os direitos humanos devem ser enunciados e interpretados à luz do valor da dignidade da pessoa humana - o que impõe sua máxima realização e observância constante.

Demais disso, tendo em vista os novos questionamentos suscitados pelos avanços da ciência no campo da genética e da biotecnologia, que, marcadamente, ultrapassam o âmbito interno dos Estados, a envolver toda a humanidade, os conceitos abertos de dignidade da pessoa humana e direitos humanos ganham pretensão de universalidade, com conteúdo normativo preenchido com base nos valores considerados fundamentais por cada cultura e naqueles que, no âmbito internacional, são "determinantes e caracterizadores dos direitos humanos, núcleo moral, político e jurídico do estado democrático de direito"306.

A relação da bioética com os direitos humanos, protegidos no âmbito interno e pelo sistema internacional, resta definida justamente pela noção da dignidade da pessoa humana, que serve de parâmetro norteador da conduta do Estado em relação a cada indivíduo e desses entre si.

Nesse cenário, são enunciados novos direitos fundamentais - advindos da nova realidade social criada pelos avanços conquistados pela ciência nos últimos anos, que teriam colocado em risco a preservação da dignidade da pessoa humana em suas novas dimensões. É certo que o complexo processo histórico de permanente construção e reconstrução dos direitos humanos permite a este sistema aberto que possa, uma vez mais, adaptar-se e reconhecer novos direitos como sendo essenciais à proteção da dignidade da pessoa humana.

\footnotetext{
${ }^{306}$ BARRETO, 2003, p. 222.
} 
A discussão bioética e a busca pelo estabelecimento de parâmetros éticos capazes de nortear a atuação de médicos e pesquisadores nasceram, justamente, em um cenário dinâmico marcado pelos avanços da ciência, especialmente no campo da genética, e pelo questionamento acerca do papel desempenhado pelo paciente e pelo sujeito de pesquisa.

A bioética, sob o paradigma principialista, estabelece limites - ainda que gerais e alteráveis no tempo e espaço - para a atuação humana e o progresso da ciência. Os princípios da autonomia, beneficência, não-maleficência e justiça funcionam, em conjunto com os princípios definidores dos direitos humanos, como horizonte para a definição de normas jurídicas que os concretizem e regulem as atividades profissionais que tratem da vida humana.

Repise-se, contudo, que, muito embora os princípios considerados como sendo as bases da bioética constituam, de fato, importantes pilares da vida moral ocidental contemporânea: essenciais para a reflexão dos temas bioéticos, não esgotam os valores considerados fundamentais pela humanidade - o que, inclusive, seria impossível de ser alcançado, uma vez que consideramos que os valores sejam inexauríveis.

São, de fato, complementados pelos princípios definidores dos direitos humanos na órbita interna e internacional.

Neste plano, o direito e a bioética complementam-se como braços de proteção da pessoa humana e dos direitos humanos quando afrontados por questões relacionadas à genética ou mesmo a outros campos da ciência, definindo princípios que devem ser sopesados caso a caso.

A ética "visa à promoção ótima da pessoa: ela é o questionamento sobre o ideal, a busca dos melhores caminhos de crescimento para a humanidade" ${ }^{307}$. A ética interroga, portanto, cada indivíduo sobre suas ações, sobre os princípios que devem ser protegidos. Ela não tem força jurídica, mas funciona como freio invisível aos abusos da conduta científica e como fonte implícita de princípios de direitos humanos.

${ }^{307}$ DURAND, 2003, p. 83. 
É de se ver que "uma pessoa não nasce ética; sua estruturação ética vai ocorrendo juntamente com o seu desenvolvimento. De outra forma, a humanização traz a ética no seu bojo" ${ }^{308}$. Em uma visão psicanalítica, para Cohen e Segre (p. 21), a eticidade do indivíduo reside na sua "percepção dos conflitos da vida psíquica (emoção X razão)" e na sua capacidade de se posicionar "de forma coerente, face a esses conflitos".

Referida noção de ética remete-nos à esfera mais íntima do indivíduo, onde se fundem razão e emoção, componentes que possuem uma dimensão pessoal diretamente influenciada por uma dimensão social axiologicamente concebida, também definida como cultura.

Tal dimensão social interrogou-nos sobre a possibilidade de afirmação de princípios universais de bioética e direitos humanos face ao argumento do relativismo cultural.

Uma proposta conciliatória, abordada e abraçada por esse trabalho, baseia-se na noção de universalidade a partir da vocação "moral única de todos os homens, que devem ser considerados como fins e não como meios, e que devem ter condições de vida que lhes permitam eleger livremente seus planos de vida", conforme anota Peces-Barba ${ }^{309}$. A dignidade da pessoa humana significa, então, que o homem, como ser comunicativo e participativo que é, deve construir consensos dialógicos, que respeitem a multiplicidade cultural e a liberdade de valores de cada um. Um projeto intercultural desse tipo considera o caráter histórico dos direitos humanos compatível com a sua universalidade. Para Cançado Trindade "compreendeu-se finalmente que a universalidade é enriquecida pela diversidade cultural, a qual jamais pode ser invocada para justificar a denegação ou violação dos direitos humanos"310.

Da atuação ética decorre a necessidade de que as decisões tomadas, especialmente no campo da medicina e da tecnologia aplicada à vida, sejam fruto de um consenso construído por meio do diálogo racional e consciente de pessoas livres, estabelecendo parâmetros éticos de atuação e proteção a valores fundamentais: vida,

\footnotetext{
${ }^{308}$ COHEN e SEGRE, 2002, p. 17

${ }^{309}$ Vide PECES-BARBA, 1999, p. 312.
} 
integridade física e psíquica, integridade do patrimônio genético, intimidade genética, igualdade e não discriminação - que podem vir a serem lesionados em virtude dos progressos biotecnológicos no campo da engenharia genética.

$\mathrm{Na}$ mesma linha de pensamento, os direitos humanos, reconhecidos como fundamentais, constituem o ethos democrático. Destarte, uma teoria discursiva insere-se, portanto, em um contexto em que o princípio democrático emerge como legitimador da constituição e do sistema normativo. Assim, em um Estado preocupado com a efetivação dos direitos humanos, o princípio da democracia, apresenta primacial relevância e conduz, segundo Habermas, com o qual concordamos, à teoria do discurso.

Conforme já destacado no curso deste texto, os princípios da bioética representaram a busca pela construção de uma ética normativa prática capaz de orientar médicos e cientistas sobre o que seria eticamente razoável diante dos novos questionamentos suscitados pelos avanços da ciência. Estabelecem uma relação de complementariedade entre si, podendo ser considerados válidos tão somente prima facie conforme terminologia introduzida por Ross ${ }^{311}$ e outrossim adotada por Alexy ${ }^{312}$.

Ou seja, em razão da busca da máxima realização de cada princípio da bioética e de cada princípio participante do conteúdo valorativo dos direitos humanos, e de todos ao mesmo tempo, casos concretos de colisão de princípios são inevitáveis.

Resta, assim, clara a importância do estabelecimento de um procedimento argumentativo decisório que seja capaz de tornar coerentes e não arbitrárias as decisões tomadas pelo judiciário e comitês de ética no que atine aos casos de colisão de princípios, a fim de garantir a proteção dos direitos humanos e da dignidade da pessoa humana.

Propomos, então, a aplicação da regra da proporcionalidade, conforme exposta por Robert Alexy: método analítico e determinado para solucionar os casos de colisão de princípios, baseado no exercício de uma ponderação que estabeleça uma relação

\footnotetext{
${ }^{310}$ CANÇADO TRINDADE, 1998, p. 173.

${ }^{311}$ ROSS, 1930.

${ }^{312} C f$.ALEXY, 1993.
} 
de precedência condicionada entre eles, aplicável a uma situação concretamente determinada.

A aplicação das sub-regras da adequação, necessidade e proporcionalidade em sentido estrito funcionam como um check list capaz de permitir aos comitês de ética e ao judiciário precisar se as suas decisões - nos casos de colisão de princípios - baseiam-se em critérios racionais. Garantir-se-á, assim, a fundamentação clara e objetiva que deve acompanhar o processo decisório que visa a maximizar a efetivação dos direitos humanos e da dignidade da pessoa humana.

Atienza, em sua obra Bioética, derecho y $\operatorname{argumentación}^{313}$, no mesmo sentido dos autores alemães Habermas e Alexy, propõe a utilização da teoria do discurso como proposta metodológica a ser aplicada na busca de soluções para os conflitos gerados pelo avanço da ciência e da biotecnologia nos dias atuais. Estabelece, então, uma estreita relação entre a bioética e o direito, de cunho metodológico e procedimental. Ele propõe, assim como Alexy, a ponderação de princípios contrapostos como meio necessário à solução de conflitos emergentes, afirmando, ademais, que a ferramenta hermenêutica desenvolvida pelo direito é de relevante utilidade para a aplicação dos princípios da bioética.

No âmbito jurídico, princípios definidores de direitos fundamentais, que consubstanciam o conteúdo valorativo da dignidade humana - aplicáveis à proteção do ser humano outrossim nos casos de ofensas decorrentes dos avanços da genética são definidos no âmbito interno e internacional.

No âmbito interno, a Constituição Federal apregoa no seu artigo $5^{\circ}$ diversos princípios de proteção ao núcleo axiológico da dignidade da pessoa humana, considerados, portanto, fundamentais, ao pleno desenvolvimento de cada ser-humano. Dentre eles, podemos destacar, desde já, o direito à vida, previsto no caput do art. $5^{\circ}$ da Carta magna brasileira, bem como o direito à liberdade, em suas múltiplas dimensões, e o

\footnotetext{
${ }^{313}$ ATIENZA, 2004.
} 
direito de autonomia do paciente e do sujeito de pesquisa - que decorre do princípio geral de liberdade previsto no caput do artigo $5^{\circ}$ da Constituição Federal.

É de se salientar, ainda, o princípio definidor do direito à igualdade, igualmente previsto no caput do art. $5^{\circ}$, do qual deriva a vedação de discriminações por motivos genéticos, sejam elas perpetradas pelo Estado ou por particulares. No mesmo sentido, o inciso XLI do referido artigo $5^{\circ}$ afirma que "a lei punirá qualquer discriminação atentatória dos direitos e liberdades fundamentais", prescrevendo o dever ao legislador ordinário, de regular os casos de discriminação.

No que concerne ao tema da confidencialidade das informações genéticas, é de se destacar que o inciso $\mathrm{X}$ da Constituição Federal expressamente define serem invioláveis "a intimidade, a vida privada, a honra e a imagem das pessoas, assegurando o direito a indenização pelo dano material ou moral decorrente de sua violação".

No âmbito internacional, a Declaração Universal sobre Bioética e Direitos Humanos enfatiza a proeminência dos princípios da beneficência e não-maleficência, da autonomia, da justiça, do respeito à diversidade cultural e ao pluralismo, da solidariedade e cooperação, da responsabilidade em relação à biosfera, da não discriminação, da confidencialidade, e da obrigação de compartilhar eqüitativamente os benefícios da pesquisa.

A proteção da dignidade humana e dos direitos humanos configura o fio condutor para a aplicação desses princípios, cuja garantia seria assegurada por um grupo de outros princípios - de natureza procedimental: honestidade e integridade, transparência e abertura, utilização de métodos científicos e racionais, consulta à comunidade e aos especialistas, eqüidade nos processos de tomada de decisões, necessidade de prevenir riscos, de construir comitês de bioética, de garantir o debate público e de levar em consideração as práticas transnacionais em geral.

Ainda, a Declaração Universal sobre o Genoma Humano e os Direitos Humanos define a obrigatoriedade do respeito à liberdade e aos direitos humanos das 
pessoas envolvidas nas pesquisas sobre o patrimônio genético e a vedação de qualquer discriminação baseada em características genéticas.

A Declaração Internacional sobre os Dados Genéticos Humanos propõe o reforço da cooperação internacional no domínio da genética humana e a maximização dos princípios da proteção da vida privada, da segurança das pessoas e da liberdade de investigação.

Tais princípios de proteção à pessoa humana definidos no âmbito interno e internacional complementam-se pelos princípios da bioética: autonomia, beneficência, não maleficência, justiça, fundando a tábua axiológica em que se devem basear as decisões éticas e jurídicas em questões envolvendo a engenharia genética e a pessoa humana. 


\section{Bibliografia:}

ADORNO, Roberto. La bioethique et la dignité de la persone. Paris: PUF, 1997.

AFONSO DA SILVA, Virgílio. "O proporcional e o razoável”, Revista dos Tribunais, no 798, 2002.

ALEXY, Robert. Teoría de los derechos fundamentales. Centro de Estudios. Constitucionales, Madrid, 1993.

. Teoria da argumentação jurídica - A teoria do discurso racional como teoria da justificação jurídica. Trad. Zilda Hutchinson Schild Silva. 2a ed. São Paulo: Landy, 2005.

ALVES, J. A. L. Os direitos humanos como tema global. São Paulo: Perspectiva, 1994.

APEL, Karl-Otto. Os conflitos de nossa época e a exigência de uma orientação éticopolítica fundamental. Estudos de moral moderna. Petrópolis: Vozes, 1994.

ARENDT, Hannah. As origens do totalitarismo. Trad. Roberto Raposo, São Paulo: Companhia das Letras, 1989.

ATIENZA, Manuel. Juridificar la bioética. In: Bioética y Derecho. Fundamentos y problemas actuales. Rodolfo Vazquez (org.) México: Fondo de Cultura Econômica, 2002.

. As razões do Direito - Teorias da argumentação jurídica Perelman, Viehweg, Alexy, MacCormick e outros. Trad. Maria Cristina Guimarães Cupertino, São Paulo: Landy, 2003.

. Bioética, derecho y argumentación. Lima-Bogotá: Temis, 2004. 
ÁVILA, Humberto Bergmann. "A distinção entre princípios e regras e a redefinição do dever de proporcionalidade", Revista Diálogo Jurídico, Salvador, CAJ - Centro de Atualização Jurídica, v. I, n. ${ }^{\circ}$ 4, julho, 2001.

BALDI, César Augusto. As múltiplas faces do sofrimento humano: os direitos humanos em perspectiva intercultural. In: BALDI, César Augusto. Direitos humanos na sociedade cosmopolita. Rio de Janeiro: Renovar, 2004.

BARBOZA, Heloisa Helena. Princípios do biodireito. In: Novos temas de bioética e biodireito. Heloisa Helena Barboza e Vicente de Paulo Barreto (org.). Rio de Janeiro: Renovar, 2003.

BARRETO, Vicente de Paulo. As relações da bioética com o biodireito. In: BARRETO, Vicente de Paulo e BARBOZA, Heloisa Helena (org). Temas de biodireito e bioética. Rio de Janeiro: Renovar, 2001.

. A idéia de pessoa humana e os limites da bioética. In: Novos temas de biodireito e bioética. Renovar: Rio de Janeiro, 2003.

. O vaso de pandora da biotecnologia: impasses éticos e jurídicos. In: Heleno Taveira Tôrres (coord.). Direito e poder nas instituições e nos valores do público e do privado contemporâneos. Estudos em homenagem a Nelson Saldanha. $1^{\text {a }}$ ed. Tamboré: Manole, 2006.

BEAUCHAMP, Tom L. e CHILDRESS, Tom. Princípios de ética biomédica. Trad: Luciana Pudenzi. São Paulo: Loyola, 2002.

BERGEL, Salvador Darío. Los derechos humanos entre la bioética y la genética. In: Acta Bioethica, 2002.

BOBBIO, Norberto. A era dos direitos. Rio de Janeiro: Campus, 1992. 
BONAVIDES, Paulo. Teoria Constitucional da Democracia Participativa. Por um Direito Constitucional de Luta e Resistência. Por uma Nova Hermenêutica. Por uma Repolitização da Legitimidade. São Paulo: Malheiros, 2001.

CABRAL, Roque. Os princípios de autonomia, beneficência não maleficência e justiça. In: Bioética. Coord. Luís Archer (et.). Lisboa: Verbo, 1996.

CANÇADO TRINDADE, Antônio Augusto. A proteção internacional dos direitos humanos no limiar do Século XXI. In: Revista dos Estudantes de Direito da Universidade de Brasília. 1998.

CANOTILHO, José Joaquim Gomes. Direito constitucional e teoria da constituição. $6^{\mathrm{a}}$ ed. Coimbra: Almedina, 1993.

CASADO GONZALEZ, María. ¿POR QUÉ BIOÉTICA Y DERECHO?. Acta bioethica., 2002, vol.8, no.2, p.183-193.

CASSIRER, Ernest. Kant, vida y doctrina. México: Fondo de Cultura Econômica, 1993.

CATTANEO, Mario. La dignità umana e pena nella filosofia di Kant. Milano: Giuffrè, 1981.

CLOUSER, K. D. e GERT, B. "A critique of principialism". Journal of Medicine and Philosophy 15, 1990.

COHEN, Cláudio e FERRAZ, Flávio Carvalho. Direitos humanos ou ética das relações. In: SEGRE, Marco e COHEN, Cláudio. Bioética. São Paulo: EDUSP, 2002.

COHEN, Cláudio e SEGRE, Marco. Definição de valores, moral, eticidade e ética. In: Bioética. SEGRE, Marco e COHEN, Cláudio, São Paulo: Edusp, 2002. 
COHEN, Cláudio. Bioética: pesquisa e deficiência. In: SEGRE, Marco e COHEN, Cláudio. Bioética. São Paulo: EDUSP, 2002.

COMPARATO, Fábio Konder. Ética: Direito, moral e religião no mundo moderno. São Paulo: Companhia das Letras, 2006.

DALLA-ROSA, Luiz Vergílio. Uma teoria do discurso constitucional. São Paulo: Landy, 2002.

DAVUTOGLU, Ahmet. Cultura global versus pluralismo cultural: hegemonia civilizacional ou diálogo e interação entre civilizações. In: BALDI, César Augusto. Direitos humanos na sociedade cosmopolita. Rio de Janeiro: Renovar, 2004.

DUARTE, Écio Oto Ramos. Teoria do discurso e correção normativa do direito. São Paulo: Landy, 2003.

DURAND, Guy. Introdução geral à bioética: História, conceitos e instrumentos. Trad. Nicolás Nyimi Campanário. São Paulo: Loyola, 2003.

DURKHEIM, Émile. De la división du travail social. Paris: Presses Universitaires de France, $10^{\mathrm{a}}$ ed., 1978.

EBERHARD, Christoph. Direitos humanos e diálogo intercultural - uma perspectiva antropológica.. In: Baldi, César Augusto. Direitos humanos na sociedade cosmopolita. Rio de Janeiro: Renovar, 2004.

ENGISH, Karl. Introdução ao pensamento jurídico. $6^{\mathrm{a}}$ ed. Lisboa: Fundação Calouste Gilbenkhian, 1988. 
. O direito privado como um sistema em construção, as cláusulas gerais no projeto do código civil brasileiro. In: Revista dos Tribunais, vol. 753, São Paulo: RT.

FERRER, Jorge José e ÁLVAREZ, Juan Carlos. Para fundamentar la bioética: Teorías y paradigmas teóricos em la bioética contemporânea. Madrid: Comillas, 2003.

FOUCAULT, Michel. As palavras e as coisas. São Paulo: Martins Fontes, 1995.

FUKUYAMA, Francis. Nosso futuro pós-humano: Consequências da Revolução da Biotecnologia. São Paulo: Rocco, 2003.

GARCIA, Maria. Limites da ciência: a dignidade da pessoa humana, a ética da responsabilidade. São Paulo: Revista dos Tribunais, 2004.

GAVARA DE CARA, Juan Carlos. Derechos fundamentales y desarrollo legislativo: la garantía del contenido esencial de los derechos fundamentales em la Ley Fundamental de Bonn. Madrid: Centro de Estudios Constitucionales, 1994.

GONÇALVES LOUREIRO, J.C. O direito à identidade genética do ser humano. In: Boletim da Faculdade de Direito da Universidade de Coimbra, 1999.

HABERMAS, Jurgen, Teorías de la verdad. In: Habermas, J. Teoría de la acción comunicativa; complementos y estudios previos. Trad. M. Jiménez. Madrid: Cátedra, 1989.

. La paix perpétuelle. Le bicentenaire d'une idée kantienne. Trad. Rainer Rochlitz, Paris: Les Éditions du CERF, 1996.

. Direito e democracia, entre facticidade e validade. Trad. de Flávio Beno Siebeneichler-UFG, Rio de Janeiro: Biblioteca Tempo Universitário, 1997. 
. Consciência moral e agir comunicativo. Trad. Guido A. de Almeida. Rio de Janeiro: Tempo brasileiro, 2003.

. O futuro da natureza humana. São Paulo: Martins Fontes, 2004.

. A ética da discussão e a questão da verdade. $1^{\text {a }}$ edição. São Paulo: Martins Fontes, 2004b.

HOSSNE, William Saad. Competência do médico. In: SEGRE, Marco e COHEN, Cláudio. Bioética. São Paulo: EDUSP, 2002.

HOTTOIS, Gilbert. Essais de philosophie bioéthique et biopolitique. Paris: J. Vrin, 1999.

KANT, Immanuel. A paz perpétua e outros opúsculos. Trad. Artur Morão. Lisboa: Edições $70,1997$.

. Fundamentos da metafísica dos costumes. São Paulo: Ediouro 2003.

. A Crítica da Razão Prática. São Paulo: Scala, 2004.

LARENZ, Karl. Derecho justo. Fundamentos de ética jurídica. Trad. Luis Diez-Picazo, Madrid: Civitas, 1985.

. Metodologia de la ciencia del derecho. Trad. Marcelino Rodríguez Molinero. Barcelona: Ariel, 1994.

LURIE P. e WOLFE, S.M. Unethical trials of interventions to reduce perinatal transmission of the immunodeficiency virus in developing countries. N. Eng.: Med. N. 337, 1997.

MARTINS-COSTA, Judith. A universidade e a construção do biodireito. In: Revista bioética. Brasília: v. 8, n. 2, pp. 229/247, 2000. 
MEDINA GUERREIRO, Manuel. La vinculación negativa del legislador a los derechos fundamentales. Madrid: McGraw-Hill, 1996.

MIRANDA, Jorge. Manual de direito constitucional. Tomo IV, Coimbra: Coimbra, 1988.

MONACO, Gustavo Ferraz de Campos. A proteção da criança no cenário internacional. Belo Horizonte: Del Rey, 2006.

NOUR, Soraya. À paz perpétua de Kant. São Paulo: Martins Fontes, 2004.

PANIKKAR, Raimundo. Seria a noção de direitos humanos um conceito ocidental? In: Baldi, César Augusto. Direitos humanos na sociedade cosmopolita. Rio de Janeiro: Renovar, 2004.

PECES-BARBA, Gregório. Curso de derechos fundamentales: Teoría General. Madrid: Imprenta Nacional del Boletín Oficial del Estado, 1999.

PEREIRA, Renata Braga da Silva. DNA: Análise biojurídica da identidade humana. In: Temas de bioética e biodireito. Heloisa Helena Barboza e Vicente de Paulo Barreto (org.). Rio de Janeiro: Renovar, 2005.

PERELMAN, Chaïm. Ética e direito. São Paulo: Martins Fontes, 1998.

PÉREZ LUÑO, Antonio Enrique. Derechos Humanos, Estado de Derecho y Constituición. Madrid: Tecnos, 1984.

. Derechos humanos y constitucionalismo ante el tercer milenio. Madrid: Marcial Pons, 1996. 
PIOVESAN, Flávia. Direitos Humanos e o direito constitucional internacional. São Paulo: Max Limonad, 1996.

- A universalidade e a indivisibilidade dos direitos humanos: desafios e perspectivas. In: BALDI, César Augusto. Direitos humanos na sociedade cosmopolita. Rio de Janeiro: Renovar, 2004.

. Direitos humanos e justiça internacional. $1^{\mathrm{a}}$ ed., São Paulo: Saraiva, 2006.

PUREZA, José Manuel. Direito internacional e comunidade de pessoas: da indiferença aos direitos humanos. In: BALDI, César Augusto. Direitos humanos na sociedade cosmopolita. Rio de Janeiro: Renovar, 2004.

REALE, Miguel. O homem e seus horizontes. São Paulo: Convívio, 1980. . Cinco temas do culturalismo. São Paulo: Saraiva, 2000.

ROMEO CASABONA, Carlos Maria. Los desafíos jurídicos de las biotecnologías en el umbral del siglo veintuno. In: Biotecnologia, derecho y dignidad humana. Carlos María Romeo Casabona e Narciso Martinéz Morán (org.) Comares, 2004.

ROSS, Alf. Direito e justiça. Trad. Edson Bini. São Paulo: Edipro, 2000.

ROSS, W. D. The right and the good. Oxford: Oxford University Press, 1930.

SALGADO, Joaquim Carlos. A idéia de justiça em Kant: seu fundamento na liberdade e na igualdade. $2^{\mathrm{a}}$ ed. Belo Horizonte: Editora UFMG, 1995.

SAMPAIO, José Adércio Leite. Direitos fundamentais. Belo Horizonte: Del Rey, 2004. 
SANTOS, Boaventura de Sousa. Por uma concepção multicultural de direitos humanos.In:BALDI, César Augusto. Direitos humanos na sociedade cosmopolita. Rio de Janeiro: Renovar, 2004.

SARLET, Ingo Wolfgang. Dimensões da dignidade. Porto Alegre: Livraria do Advogado, 2005.

SCHRAMM, Fermin Roland. Os princípios da bioética. In: Marco Segre (org). Aquestão ética e a saúde humana. São Paulo: Atheneu, 2006.

SÈVE, Lucien. Qu'est-ce que la personne humaine? Bioéthique et démocratie. Paris: La Dispute, 2006.

SGRECCIA, E. Manual de bioética. Fundamentos e ética biomédica. São Paulo: Loyola, 1996.

STEINMETZ, Wilson Antônio. Colisão de direitos fundamentais e princípio da proporcionalidade. Porto Alegre: Livraria do Advogado, 2001.

VASQUEZ, Guilhermo Hoyos. Bioética e moral comunicativa. In: Bioética: poder e injustiça. Volnei Garrafa e Leo Pessini (org.) São Paulo: Loyola, 2003.

VAZQUEZ, Adolfo Sanchez. Ética. 16ª ed. Rio de Janeiro: Civilização brasileira, 1996.

Revista Seqüência, n. 26, 1993, Florianópolis: DAUFSC.

Editorial da Revista de Bioética e Derecho, número 06, marzo de 2006.

www.unesco.org.br

Entrevista a Marcos Pivetta e Mariluce Moura. In:Revista Pesquisa, n. 110, abril de 2005. 